\title{
Bank Erosion of Navigation Canals in the Western and Central Gulf of Mexico
}

USGS Open-File Report 2010-1017

OCS Study BOEMRE 2010-039

U.S. Department of the Interior

U.S. Geological Survey
U.S. Department of the Interior Bureau of Ocean Energy Management, Regulation and Enforcement Gulf of Mexico OCS Region 



\section{Bank Erosion of Navigation Canals in the Western and Central Gulf of Mexico}

By Cindy A. Thatcher, Stephen B. Hartley, and Scott A. Wilson

Prepared in cooperation with Bureau of Ocean Energy Management, Regulation and Enforcement, Gulf of Mexico OCS Region

USGS Open-File Report 2010-1017

OCS Study BOEMRE 2010-039

U.S. Department of the Interior

U.S. Geological Survey
U.S. Department of the Interior Bureau of Ocean Energy Management, Regulation and Enforcement Gulf of Mexico OCS Region 


\section{U.S. Department of the Interior KEN SALAZAR, Secretary \\ U.S. Geological Survey Marcia K. McNutt, Director}

\section{U.S. Geological Survey, Reston, Virginia: 2011}

This and other USGS information products are available at http://store.usgs.gov/

U.S. Geological Survey

Box 25286, Denver Federal Center

Denver, CO 80225

To learn about the USGS and its information products visit http://www.usgs.gov/ 1-888-ASK-USGS

Any use of trade, product, or firm names is for descriptive purposes only and does not imply endorsement by the U.S. Government.

Although this report is in the public domain, permission must be secured from the individual copyright owners to reproduce any copyrighted materials contained within this report.

Suggested citation:

Thatcher, C.A., Hartley, S.B., and Wilson, S.A., 2011, Bank erosion of navigation canals in the western and central Gulf of Mexico: U.S. Geological Survey Open-File Report 2010-1017 and OCS Study BOEMRE 2010-039, 32 p, 2 app. 


\section{Disclaimer}

This report has been technically reviewed by the Bureau of Ocean Energy Management, Regulation and Enforcement (BOEMRE), and it has been approved for publication. Approval does not signify that the contents necessarily reflect the views and policies of the BOEMRE, nor does mention of trade names or commercial products constitute endorsement or recommendation for use. It is, however, exempt from review and compliance with the BOEMRE editorial standards.

\section{Report Availability}

Bureau of Ocean Energy Management,

Regulation and Enforcement

Gulf of Mexico OCS Region

Public Information Office (MS 5034)

1201 Elmwood Park Boulevard

New Orleans, Louisiana 70123-2394

Telephone requests may be placed at

(504) 736-2519, 1-800-200-GULF, or

Rush Orders: 1-800-553-6847

Fax: (504) 736-2620

\section{Acknowledgments}

Funding for this study was provided by Bureau of Ocean Energy Management, Regulation and Enforcement (BOEMRE). The authors would like to thank BOEMRE personnel Greg Kozlowski, Casey Rowe, and Larry Hartzog for their support of this project. We also thank Aaron Pierce at Nicholls State University, Thibodeaux, La., and Tara Miller of the National Oceanic and Atmospheric Administration's Coastal Services Center, Charleston, S.C., for reviewing the report.

We thank U.S. Geological Survey staff Sijan Sapkota for statistical assistance, Greg Steyer for his advice and comments on an earlier draft of this report, Connie Herndon for her thorough editorial review, and Natalie Trahan for her assistance with the design and layout of the document. 


\section{Contents}

Abstract

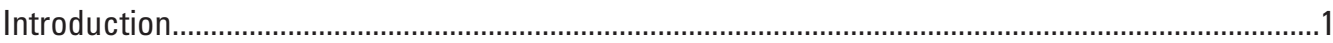

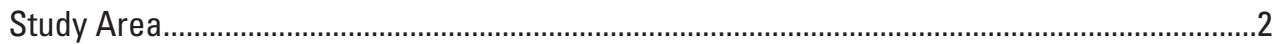

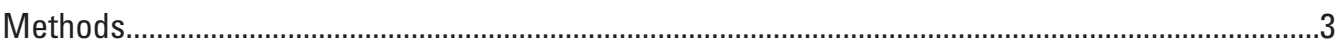

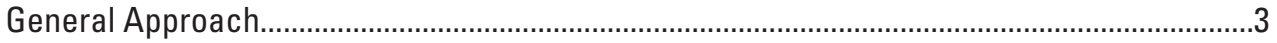

Shoreline Position .............................................................................................................

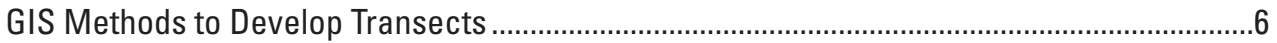

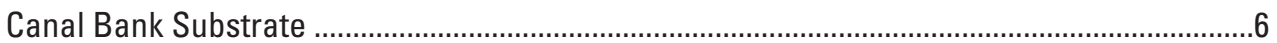

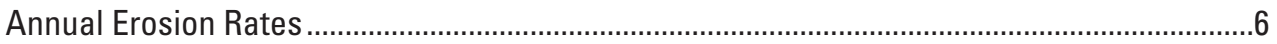



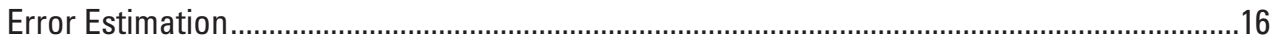





Shoreline Change Rates …………....................................................................................

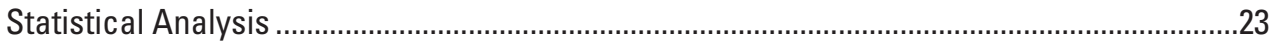

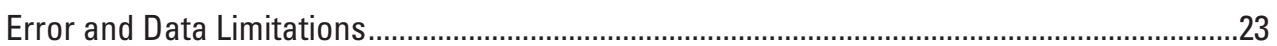

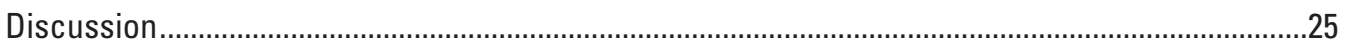

Conclusions



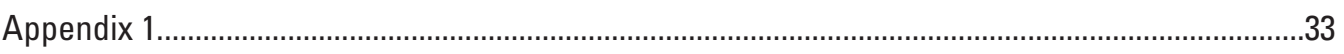

Appendix 2

\section{Figures}

1. Map of Minerals Management Service-designated planning areas in the Gulf of Mexico and Outer Continental Shelf-related navigation canals

2. Bayou Lafourche Cutoff, La., navigation canal

3. Section of Baptiste Collette Bayou channel, La., demonstrating linear armored banks

4. Map showing how net shoreline movement is calculated for each transect to measure erosion rates from 1978-2006.

5. Relationship between canal width and years elapsed for Transect 1

in the Bayou Lafourche Cutoff canal in Louisiana, 1978-2006

6. Percentage of organic content of soils surrounding navigation canals

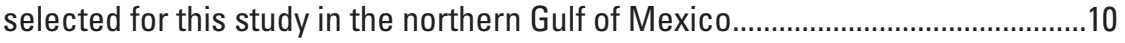

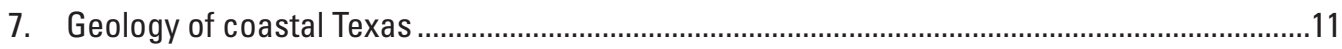

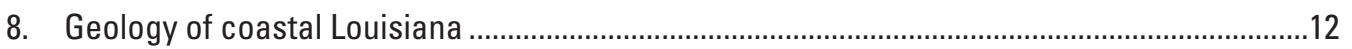

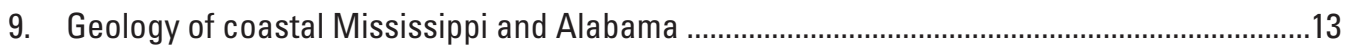

10. Marsh vegetation types in coastal Louisiana ..................................................................14

11. Marsh vegetation types in coastal Louisiana .......................................................................

12. Rates of annual shoreline change associated with the west side

of the Bayou Lafourche Cutoff navigation canal, La ...

13. Bank of the Houma Navigation Canal in Louisiana, taken in 2008, showing a short segment of rock rip-rap which is obscured 
14. Bank of the Houma Navigation Canal, La., taken in 2008, showing

a thin strip of degraded natural shoreline.

15. Mudflats in the channel near the mouth of the Main Pass channel, La.

\section{Tables}

1. Navigation canals within the study area in the northern Gulf of Mexico

2. Acquisition dates for aerial photographs that were used to determine shoreline position for navigation canals within the study area in the northern Gulf of Mexico ...

3. Total length of canal banks by substrate type within navigation canals in the northern Gulf of Mexico in 2005-06

4. Linear length of canals by substrate type, measured in 50-m increments from the canal center line within navigation canals in the northern Gulf of Mexico in 2005-06.....

5. Percent of canals in each bank substrate type, calculated from the linear length of canal banks within navigation canals in the northern Gulf of Mexico in 2005-06.

6. Mean erosion rate for nonarmored portions of navigation canals in the northern Gulf of Mexico, 1978-2006.

7. Mean annual change in canal width for nonarmored portions of navigation canals in the northern Gulf of Mexico, 1978-2006

8. Mean annual change in canal width for nonarmored portions of navigation canals in the northern Gulf of Mexico, 1978-2006, based on geologic region.....

9. Mean annual change in canal width for nonarmored portions of navigation canals in the northern Gulf of Mexico, 1978/79-1996/98, based on vegetation type.....

10. Mean annual change in canal width for nonarmored portions of navigation canals in the northern Gulf of Mexico, 1996/98-2005/06, based on vegetation type

11. Mean annual change in canal width for nonarmored portions of navigation canals in the northern Gulf of Mexic0, 1978-2006, based on substrate type

12. Estimated measurement errors (meters) for determining shoreline position in navigation canals in the northern Gulf of Mexico, 1978-2006.

13. Difference in rates of shoreline change between two time periods (1978/79-1996/98 and 1996/98-2005/06) in navigation canals in the northern Gulf of Mexico.

\section{Conversion Factors}

SI to Inch/Pound

\section{Multiply}

To obtain

Length

meter $(\mathrm{m})$

3.281

0.6214

foot ( $\mathrm{ft})$

kilometer $(\mathrm{km})$

mile (mi) 



\title{
Bank Erosion of Navigation Canals in the Western and Central Gulf of Mexico
}

\author{
By Cindy A. Thatcher, Stephen B. Hartley, and Scott A. Wilson
}

\section{Abstract}

Erosion of navigation canal banks is a direct cause of land loss, but there has been little quantitative analysis to determine why certain major canals exhibit faster widening rates (indicative of erosion) than others in the coastal zones of Texas, Louisiana, Mississippi, and Alabama. We hypothesize that navigation canals exhibit varying rates of erosion based on soil properties of the embankment substrate, vegetation type, geologic region (derived from digital versions of state geologic maps), and the presence or absence of canal bank armaments (that is, rock rip-rap, concrete bulkheads, or other shoreline protection structures). The first objective of this project was to map the shoreline position and substrate along both banks of the navigation canals, which were digitized from 3 different time periods of aerial photography spanning the years of $1978 / 79$ to $2005 / 06$. The second objective was to quantify the erosion rates of the navigation canals in the study area and to determine whether differences in erosion rates are related to embankment substrate, vegetation type, geologic region, or soil type. To measure changes in shoreline position over time, transects spaced at 50-m (164-ft) intervals were intersected with shorelines from all three time periods, and an annual rate of change was calculated for each transect. Mean annual rates of shoreline change ranged from 1.75 $\mathrm{m} /$ year (5.74 ft/year) on the west side of the Atchafalaya River, La., where there was shoreline advancement or canal narrowing, to $-3.29 \mathrm{~m} /$ year $(-10.79 \mathrm{ft} /$ year) on the south side of the Theodore Ship Channel, Ala., where there was shoreline retreat or erosion. Statistical analysis indicated that there were significant differences in shoreline retreat rates according to geologic region and marsh vegetation type, and a weak relationship with soil organic content. This information can be used to better estimate future land loss rates associated with navigation canals and to prioritize the location of restoration and erosion mitigation efforts. Combining all canals together, our results also showed that canal erosion rates have slowed in recent years, with an average canal widening rate of -0.99 $\mathrm{m} /$ year (-3.25 ft/year) for the 1996/98-2005/06 time period compared to $-1.71 \mathrm{~m} /$ year $(-5.61 \mathrm{ft} /$ year) for the earlier 1978/79-1996/98 time period. Future research could focus on obtaining detailed vessel traffic information for individual canals, which is likely a factor that influences canal bank erosion rates.

\section{Introduction}

Land loss within coastal wetland systems throughout the northern Gulf of Mexico coast is occurring at a high rate by all accounts (Morton, Bernier, and others, 2005; Barras and others, 2003; Day and others, 2000). Coastal land loss is caused by a variety of natural processes, including sea level rise, subsidence, and storm events (U.S. Army Corps of Engineers [USACE], 2004). Anthropogenic factors such as industrial development, agriculture, hydrologic alterations, vessel wakes, and construction of navigation canals and pipelines also contribute to land loss (USACE, 2004).

Navigation canals can have both direct and indirect impacts on land loss within the Gulf of Mexico region (Johnston and others, unpub. data, 2007). Although navigation canals may contribute to land loss beyond the navigation canal boundary through saltwater intrusion and the alteration of historical water flow patterns by spoil banks (Baumann and Turner, 1990; Johnston and others, unpub. data, 2007), this study focuses exclusively on land loss caused by erosion at the landwater interface along navigation canal banks.

Erosion of navigation canal banks is a direct cause of land loss, but there has been little quantitative analysis to determine why certain canals exhibit faster widening rates (indicative of erosion) than others. To estimate land loss, Bureau of Ocean Energy Management, Regulation and Enforcement (BOEMRE) requires information on the annual erosion rates of the navigation canals in the Gulf of Mexico. We hypothesize that navigation canals exhibit varying rates of erosion based on soil properties of the embankment substrate, vegetation type, geologic region (derived from digital versions of state geologic maps), and the presence or absence of canal bank armaments (that is, rock rip-rap, concrete bulkheads, or other shoreline protection structures).

Morton, Bernier, and others (2005) found that the highest rates of shoreline retreat in the Gulf of Mexico are found 
along the headland shores of the Mississippi River Delta and the barrier islands of Louisiana; however, that study did not examine inland shoreline retreat associated with navigation canals. Johnson and Gosselink (1982) examined widening rate differences among navigation canals in the Leeville Oil and Gas Field in Lafourche Parish, La., but no studies have been conducted to determine long-term erosion rates within navigation canals throughout the Gulf of Mexico region. In addition, the Johnson and Gosselink (1982) study was based on data collected from canals that had few bank armaments constructed at the time. As of 2008, a significant portion of many of the larger navigation canals are armored or have infrastructure built up to the water's edge, minimizing any further erosion. Therefore, the first objective of this project was to map the shoreline position and substrate along both banks of the navigation canals. The second objective was to quantify the erosion rates of the navigation canals in the study area and to determine whether differences in erosion rates are related to embankment substrate, vegetation type, geologic region, or soil type. This information can be used to better estimate future land loss rates associated with existing or proposed navigation canals.

\section{Study Area}

The study area is within the BOEMRE-designated western and central planning areas of the Outer Continental Shelf (OCS) region, which includes the coastal zones of Texas, Louisiana, Mississippi, and Alabama (fig. 1). The canals in the study (table 1), the largest or most important for navigation within the two planning regions, vary in length from approximately $4 \mathrm{~km}$ (Theodore Ship Channel, Ala.) up to 59 km (Freshwater Bayou Channel, La.). In total, approximately 356 linear kilometers of navigation canals were included in the study area.

In the northern Gulf of Mexico, the coastal zone is a flat, gently sloping landscape with a subtropical climate. Ecoregions intersected by navigation canals include the Western Gulf Coastal Plain, the Mississippi Alluvial Plain, and the Southern Coastal Plain (Omernik, 1987). In Texas, the Galveston Ship Channel and Freeport Harbor Channel are located within the barrier islands and coastal marshes of the Western Gulf Coastal Plain ecosystem. This region is characterized by a gradient of freshwater to saltwater marshes with numerous rivers, tidal channels, and

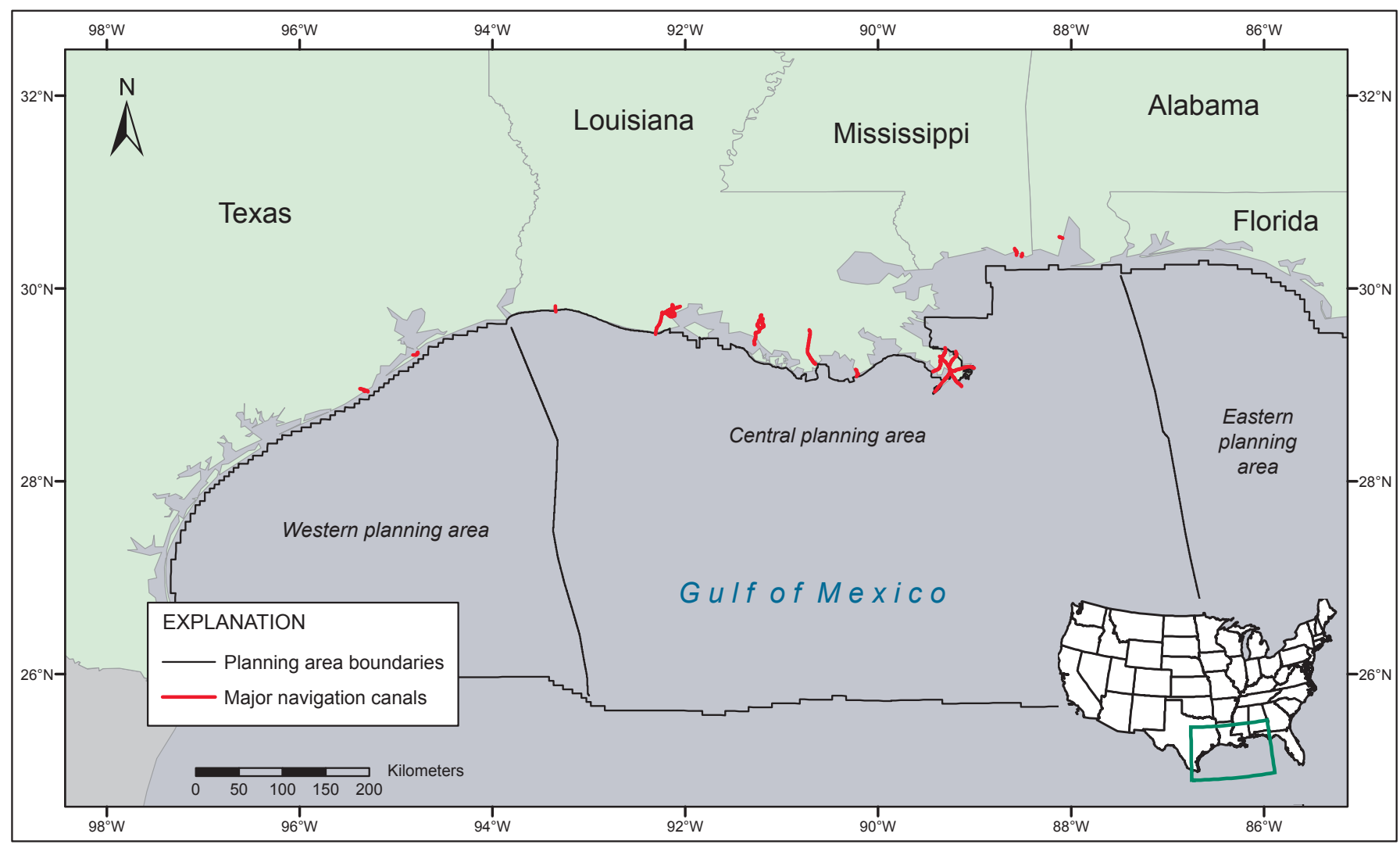

Figure 1. Map of Bureau of Ocean Energy Management, Regulation and Enforcement-designated planning areas in the Gulf of Mexico and Outer Continental Shelf-related navigation canals. 
Table 1. Navigation canals within the study area in the northern Gulf of Mexico.

[OCS; Outer Continental Shelf; Y, yes; N, no]

\begin{tabular}{|c|c|c|c|c|}
\hline Name of Canal & OCS & Service Base & Length (km) & Number of transects (50-m spacing) \\
\hline Atchafalaya River, La. & $\mathrm{Y}$ & Morgan City & 57 & 1,947 \\
\hline Baptiste Collette Bayou channel, La. & $\mathrm{Y}$ & Venice & 13 & 391 \\
\hline Calcasieu Ship Channel, La. & Y & Cameron & 7 & 241 \\
\hline Freeport Harbor Channel, Tex. & $\mathrm{Y}$ & Freeport & 12 & 391 \\
\hline Galveston Ship Channel, Tex. & $\mathrm{N}$ & Galveston & 6 & 247 \\
\hline Houma Navigation Canal, La. & $\mathrm{Y}$ & Houma & 42 & 1,575 \\
\hline Main Pass channel, La. & $\mathrm{Y}$ & Venice & 19 & 640 \\
\hline Mississippi River Mouth Pass, La. & Y & Venice & 20 & 676 \\
\hline South Pass channel, La. & $\mathrm{Y}$ & Venice & 22 & 774 \\
\hline Southwest Pass channel, La. & $\mathrm{Y}$ & Venice & 30 & 667 \\
\hline Theodore Ship Channel, Ala. & $\mathrm{N}$ & Theodore & 4 & 128 \\
\hline Tiger Pass channel, La. & $\mathrm{N}$ & Venice & 20 & 443 \\
\hline
\end{tabular}

canals (Omernik, 1987). The marsh vegetation in these coastal areas has a salinity gradient ranging from fresh to saline, with intermediate and brackish marsh types in transition zones.

The Galveston Bay and Freeport areas in Texas are exhibiting subsidence associated with groundwater pumping and the extraction of hydrocarbons. The Calcasieu Ship Channel and Freshwater Bayou Channel are located within the coastal marshes of the chenier plain of western Louisiana. The chenier plain is a series of mud flats and sandy beach ridges running parallel to the shore, formed by the westward flow of sediment. Several navigation canals in the study area are located within the deltaic plain of coastal Louisiana, which includes a gradient of freshwater to saltwater marshes of the Atchafalaya River and Mississippi River Deltas.

The deltaic plain was formed by a series of overlapping delta lobes resulting from the shifting courses of the Mississippi River over the past 6,000-7,000 years (Day and others, 2000). The Mississippi River Delta in Louisiana is experiencing the highest rates of subsidence and associated land loss in the United States (Ramsey and Penland, 1989); however, the Atchafalaya River Delta is generally increasing in land area, while other parts of the Mississippi River Delta are declining through subsidence and loss of sediment and nutrient inputs.

The Pascagoula Channel in Mississippi is located within coastal marshes of the Gulf Coast Flatwoods ecosystem. The Gulf Coast Flatwoods is composed of nearly level terraces and deltaic deposits of sands and clays (Omernik, 1987). In Alabama, the Theodore Ship Channel is also located within the Gulf Coast Flatwoods ecosystem and empties into Mobile Bay estuary in Alabama, $22 \mathrm{~km}$ inland from the Gulf of Mexico.

\section{Methods}

\section{General Approach}

The methods and transect spacing for this study were derived from the U.S. Geological Survey's (USGS) National Assessment of Shoreline Change Project, which provides a national standard for measuring shoreline change (Morton and others, 2004). An advantage to adopting the standards of the National Assessment of Shoreline Change Project is that the project employs commonly used methods to measure statistical uncertainty for the rate of shoreline change. Furthermore, the National Assessment of Shoreline Change Project provides standardized, repeatable methods that can be used to provide periodic updates to coastal erosion and land loss rates in a consistent manner (Morton and others, 2004).

Analytical techniques performed by using geographic information systems (GIS) that are typically used to quantify beach erosion (Morton and others, 2004) were applied to measure erosion within navigation canals. Historical canal bank positions were digitized from 1978/79 and 1996/98 aerial photography, and the most recent canal bank locations 
were digitized from 2005/06 aerial photography. To measure changes in shoreline position over time, transects intersecting the canal bank were spaced at 50-m (164-ft) intervals. The shoreline position was determined for all three time periods at transect locations and was used to calculate an annual rate of change for each transect.

\section{Shoreline Position}

Aerial photography acquired during three different time periods was used to map the position of navigation canal banks (table 2). High-resolution, color, aerial photography with a $0.15-\mathrm{m}(6-\mathrm{ft})$ pixel resolution from 2006 and $1-\mathrm{m}$ (3.3-ft) resolution photography from 2005 was used to digitize the canal banks, to determine the length of the navigation canals, and to identify the bank substrate type. Canal banks were also digitized based on 1996, 1997, or 1998 digital aerial photos with a pixel resolution of $1 \mathrm{~m}(3.3 \mathrm{ft})$. To represent a third time period, canal banks were digitized from analog aerial photographs that were scanned and registered for 1978 in Louisiana, 1979 in Texas, 1979 in Mississippi, and 1979 in Alabama; photographs were of varying resolutions (2.11-2.97 $\mathrm{m}[6.9-9.7 \mathrm{ft}])$.

Delineating shorelines based on LiDAR (airborne light detection and ranging) surveys is currently the preferred method for shoreline mapping because it provides a very accurate and consistent delineation of the land-water interface.

Table 2. Acquisition dates (by year) for aerial photographs that were used to determine shoreline position for navigation canals within the study area in the northern Gulf of Mexico.

\begin{tabular}{llll}
\multicolumn{1}{c}{ Channel name } & Year & Year & Year \\
\hline Atchafalaya River, La. & 1978 & 1998 & 2005 \\
Baptiste Collette Bayou channel, La. & 1978 & 1998 & 2006 \\
Bayou Lafourche Cutoff, La. & 1978 & 1998 & 2005 \\
Calcasieu Ship Channel, La. & 1978 & 1996 & 2006 \\
Freeport Harbor Channel, Tex. & 1979 & 1998 & 2005 \\
Freshwater Bayou Channel, La. & 1978 & 1996 & 2006 \\
Galveston Ship Channel, Tex. & 1979 & 1998 & 2006 \\
Houma Navigation Canal, La. & 1978 & 1998 & 2006 \\
Main Pass channel, La. & 1978 & 1998 & 2006 \\
Mississippi River Mouth Pass, La. & 1978 & 1998 & 2005 \\
Pascagoula Channel, Miss. (large channel) & 1979 & 1998 & 2006 \\
Pascagoula Channel, Miss. (small channel) & 1979 & 1998 & 2006 \\
Pass a Loutre channel, La. & 1978 & 1996 & 2006 \\
South Pass channel, La. & 1978 & 1998 & 2006 \\
Southwest Pass channel, La. & 1978 & 1998 & 2006 \\
Theodore Ship Channel, Ala. & 1979 & 1997 & 2006 \\
Tiger Pass channel, La. & 1978 & 1998 & 2006 \\
\hline
\end{tabular}

The shoreline is extracted at the mean high-water line datum based on highly accurate, LiDAR-derived elevation data, rather than through interpretation of aerial photography; however, extraction of shorelines by LiDAR is generally not effective in muddy, wetland environments such as the Mississippi and Atchafalaya River Deltas (Morton and others, 2004), which occur throughout the majority of our study area. In addition, LiDAR data is not available for the entire study area; therefore, to map the shorelines of navigation canal banks, we used traditional photointerpretation of aerial photography.

The land-water interface, or shoreline, along the banks of navigation canals was digitized. The land-water interface is dynamic, with changes in water levels resulting from waves, tides, storm surge, and other factors. In addition, the canal bank substrate throughout the study area is heterogeneous, requiring several shoreline proxies to represent the land-water interface. Vegetated banks were digitized at the waterline, and mud banks were digitized at the landward edge of the canal. Sandy banks were digitized at the boundary between wet and dry shoreline (represented as a tonal change in aerial photographs), which is commonly referred to as the high water line. This type of boundary represents the upper extent of the previous high tide and is less susceptible to daily changes in water levels (Boak and Turner, 2005; Stockdon and others, 2002) than other proxies on sandy shores, such as the debris line. The presence and type of bank armament (for example, sand, rock rip-rap, degraded rock rip-rap, bulkhead, vegetated canal bank or other materials) was recorded, and the center line of constructed bank armaments (for example, rock rip-rap) was digitized. Where open water was visible behind bank armaments, the land-water interface behind the bank armament was also digitized.

To map canal bank substrate and to map the location and length of canal bank armaments, the entire canal bank was digitized along each navigation canal based on the 2005 or 2006 aerial photos; however, it was not necessary to digitize the entire shoreline from the $1978 / 79$ or $1996 / 98$ time period. Instead, where each transect intersected the canal bank, a short line was digitized at the land-water interface. The line is required by the software to be only long enough to represent the canal bank position where the transect intersection is located. The Bayou Lafourche Cutoff, La., navigation canal is shown in figure 2 as an example of shoreline digitizing based on three different years of aerial photography. 


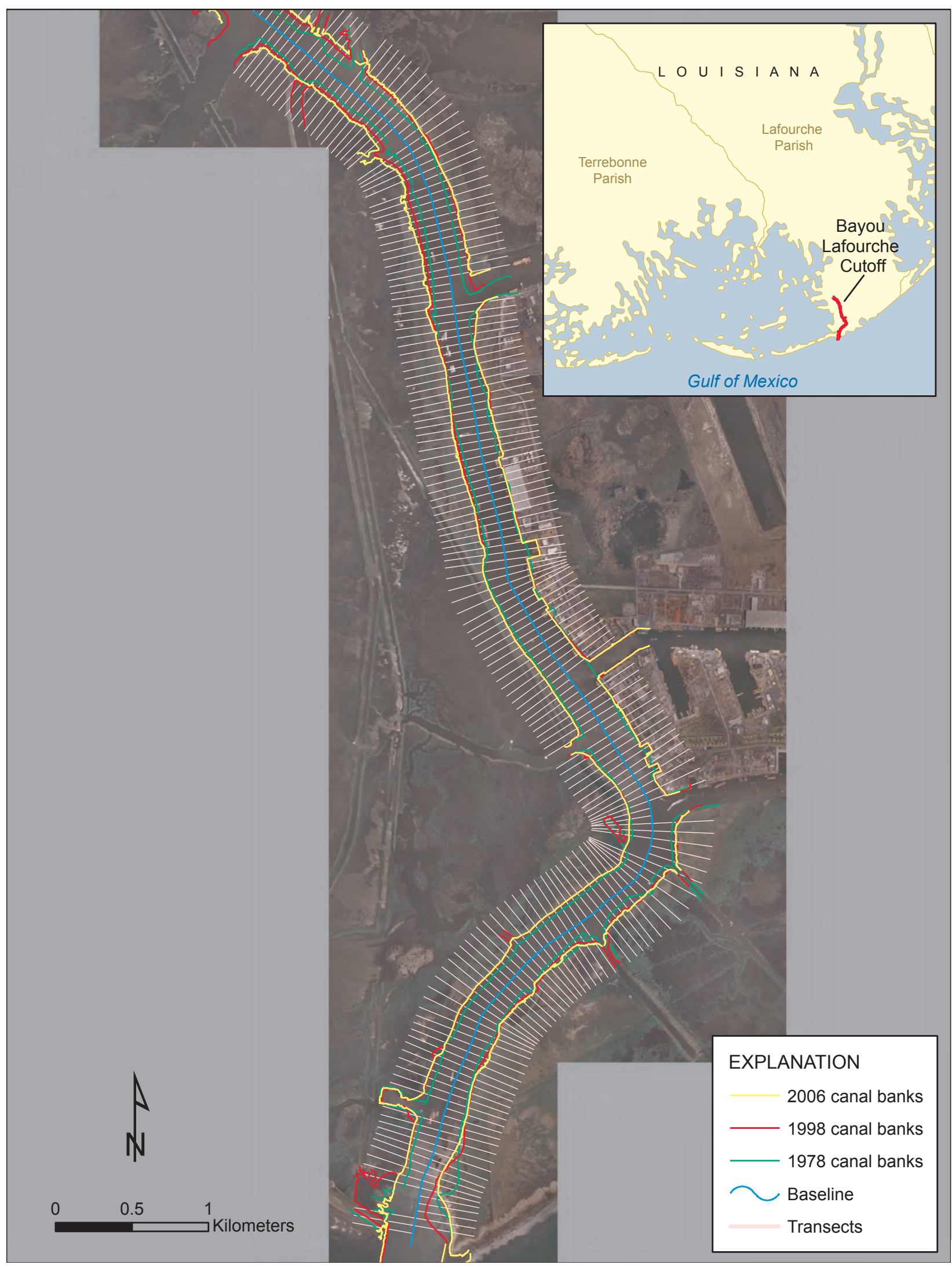

Figure 2. Bayou Lafourche Cutoff, La., navigation canal (shown as an example of how bank positions of navigation canals were digitized for three time periods). Transects were generated at 50-m intervals to measure erosion rates from 1978-2006 within navigation canals included in the study area within the northern Gulf of Mexico. The background imagery consists of 2006 aerial photographs. 
Similar figures are provided for the other navigation canals in appendix 1 .

\section{GIS Methods to Develop Transects}

A line digitized along the center of the navigation canals was used as a reference point for measuring erosion from three different time periods. This reference point functions in the same manner as a datum when taking vertical measurements and is strictly used to measure changes in shoreline position. We used Digital Shoreline Analysis System (DSAS) software, which was developed by USGS for use with ArcGIS (ESRI, Redlands, Calif.) as part of the National Assessment of Shoreline Change Project (Morton and others, 2004), to automate the production of transects (Thieler and others, 2005). Because that software was designed to measure beach erosion where only one shoreline is present, rather than canal erosion where there are two shorelines (canal banks) to measure, transects were generated separately for each side of the navigation canals. Transects were generated at 50-m (164-ft) intervals, perpendicular to the center of the canal, and were greater than $300 \mathrm{~m}(984 \mathrm{ft})$ in length to ensure that each transect intersected the canal bank positions from all three time periods.

Transect spacing of $50 \mathrm{~m}(164 \mathrm{ft})$ is commonly used in shoreline erosion studies (for example, Dolan and others, 1991; Gibeaut and others, 2001) and is the standard used in the USGS National Assessment of Shoreline Change Project (Morton and others, 2004; Morton, Miller, and Moore, 2005). A total of more than 11,000 transects were generated for use in the erosion analysis. Transects were manually deleted to avoid sampling in areas where canal banks were absent for any of the three time periods; for example, because of the presence of inlets or the disappearance of a canal bank over time (Morton and others, 2004).

\section{Canal Bank Substrate}

Some navigation canals in the study area were formed by deepening and/or widening existing natural water bodies, while others were constructed through wetland or upland landforms. Most often, the navigation canals were originally constructed with nonarmored banks; however, some portions of major navigation canals are now armored with rock rip-rap, concrete, or other materials to minimize erosion. In the past, no information on the location and extent of canal armaments was available to help refine predictions of land loss caused by bank erosion. By quantifying the differing erosion rates for each bank substrate type, future land loss rates caused by canal widening can be better predicted for individual canals.

Canal bank substrate was identified based on aerial photography from 1978/79, 1996/97, and 2005/06; that information was added to the table of attributes associated with the digitized canal banks. Categories of canal bank substrate included natural/vegetated, rock rip-rap, degraded rock rip-rap, shell, sand, concrete bulkhead, dredge spoil, and other/unidentified. Because the 2005 aerial photographs have a pixel resolution of only $1 \mathrm{~m}$ compared to the $0.15-\mathrm{m}$ resolution of the 2006 photography, canal bank substrate was sometimes difficult to determine in areas where only the 2005 photography was available (table 2). To help resolve this problem, airborne video images of the canals that were taken at an oblique angle in 2008 were used to determine canal bank substrate where necessary. Approximately 15,000 images, which were acquired at an altitude of 500 to $2,000 \mathrm{ft}$, are provided via a Google (Google, Inc., Mountain View, Calif.) map interface at http://nwrcwebapps.cr.usgs.gov/canals/. A field survey was conducted of the Houma Navigation Canal, La., by boat from the city of Houma to the Gulf of Mexico in order to verify the substrate type of the canal bank. That particular canal was chosen for the field survey because overhanging trees along parts of the canal obscured the canal banks in the aerial photographs, making it more difficult to determine bank substrate.

The total length of each canal by substrate type was calculated by using two different methods. First, the total length of the shoreline was measured along the canal banks at the land-water interface; however, natural/vegetated canal banks are typically much more sinuous than armored canal banks (fig. 3) and are thus disproportionally represented in statistics on canal bank length. Therefore, shoreline length was also measured as a straight line along the canal bank, parallel to the canal center line. In this measurement, the canal bank is represented as a relatively straight line parallel to the center of the canal, regardless of small bends or inlets along the canal banks. Linear measurements of canal bank length were reported separately for the two banks of each canal. The linear measurements of canal bank length were used to represent the proportion of canal bank within each substrate type in order to measure, for example, the percent of canal banks that were armored versus those that were nonarmored.

\section{Annual Erosion Rates}

The transect length between the reference (the center of the navigation canal) and the canal bank was calculated for each time period (fig. 4). Differences in transect length were used to determine net canal bank movement (that is, the distance between the 1978/79 and 1996/98 canal bank position, the 1996/98 and 2005/06 canal bank position, and the 1978/79 and 2005/06 canal bank position). Long-term erosion rates were derived by using simple linear regression. Shortterm erosion rates (1978/79-1996/98; 1996/98-2005/06) were calculated by using the endpoint rate (EPR) technique (Dolan and others, 1991).

To calculate erosion rates by using the EPR technique, the net measurement of canal bank movement is divided by the number of years elapsed between the oldest and youngest measurements, yielding an annualized erosion rate (Dolan and others, 1991). For the current study, the EPR was calculated 




Figure 3. Section of Baptiste Collette Bayou channel, La., demonstrating linear armored banks compared with the sinuous shape of natural/vegetated banks. The background imagery consists of 2006 aerial photographs.

from the center of the canal to both sides of the navigation canals for three temporal periods: (1) 1978/79 to $1996 / 98$, (2) $1996 / 98$ to $2005 / 06$, and (3) $1978 / 79$ to $2005 / 06$ (the entire length of time). EPR results are provided for comparison to erosion rates that were calculated by using the linear regression method and to examine differences in short-term erosion rates between two time periods.

Linear regression is frequently used to determine rates of shoreline change in situations where there are three or more temporal shoreline samples, because linear regression includes data from all time periods in erosion rate estimates, rather than only the youngest and oldest shorelines, as in the EPR method. Predictions based on linear regression perform better on average than EPR predictions (Honeycutt and others, 2001); however, linear regression is susceptible to outlier effects, and if temporal shoreline samples are clustered, some dates will have a greater impact on the regression than others (Dolan and others, 1991). In this study, linear regression was used to calculate the annual rate of erosion at each transect along canal banks. In this technique, a least-squares regression line is fitted to all three shoreline points for a particular transect (for example, 1978, 1998, and 2006 shorelines), and the slope of the line represents the annual erosion rate (Dolan and others, 1991; fig. 5). To provide a measurement of statistical uncertainty, the standard error, minimum, and maximum canal bank change rates are also reported for all transects (Zuzek and others, 2003) on each side of a navigation canal.

\section{Statistical Analysis}

Because the goal of the study was to determine long-term erosion rates, individual transects were removed as necessary to avoid any bias associated with sampling in areas where human engineering is known to have caused changes in canal width since 1978/79. These changes include the construction of new canal bank armaments or new navigation canals and canal bank restoration activities. Transects were designated as intersecting natural substrates (nonarmored) or intersecting armored substrates (for example, rock or concrete bulkheads) for each time period (1978/79, 1996/98, 2005/06). Next, transects that were not consistently nonarmored throughout all three time periods were deleted. These transects were removed because the addition of canal bank armaments is a direct anthropogenic change that would bias long-term erosion rates. In other words, it is inappropriate to measure erosion at locations where rock walls or concrete bulkheads are present. Finally, transects located within the boundaries of wetland restoration sites funded by the Coastal Wetlands Planning, Protection, and Restoration Act (CWPPRA) were also deleted.

To report mean annual change rates for canal bank movement, we calculated the mean change in shoreline position for the left and right side of each canal separately and added the two means together. Thus, the reported mean value represents a total rate per year of canal widening (or narrowing). A negative value indicates that a canal has 


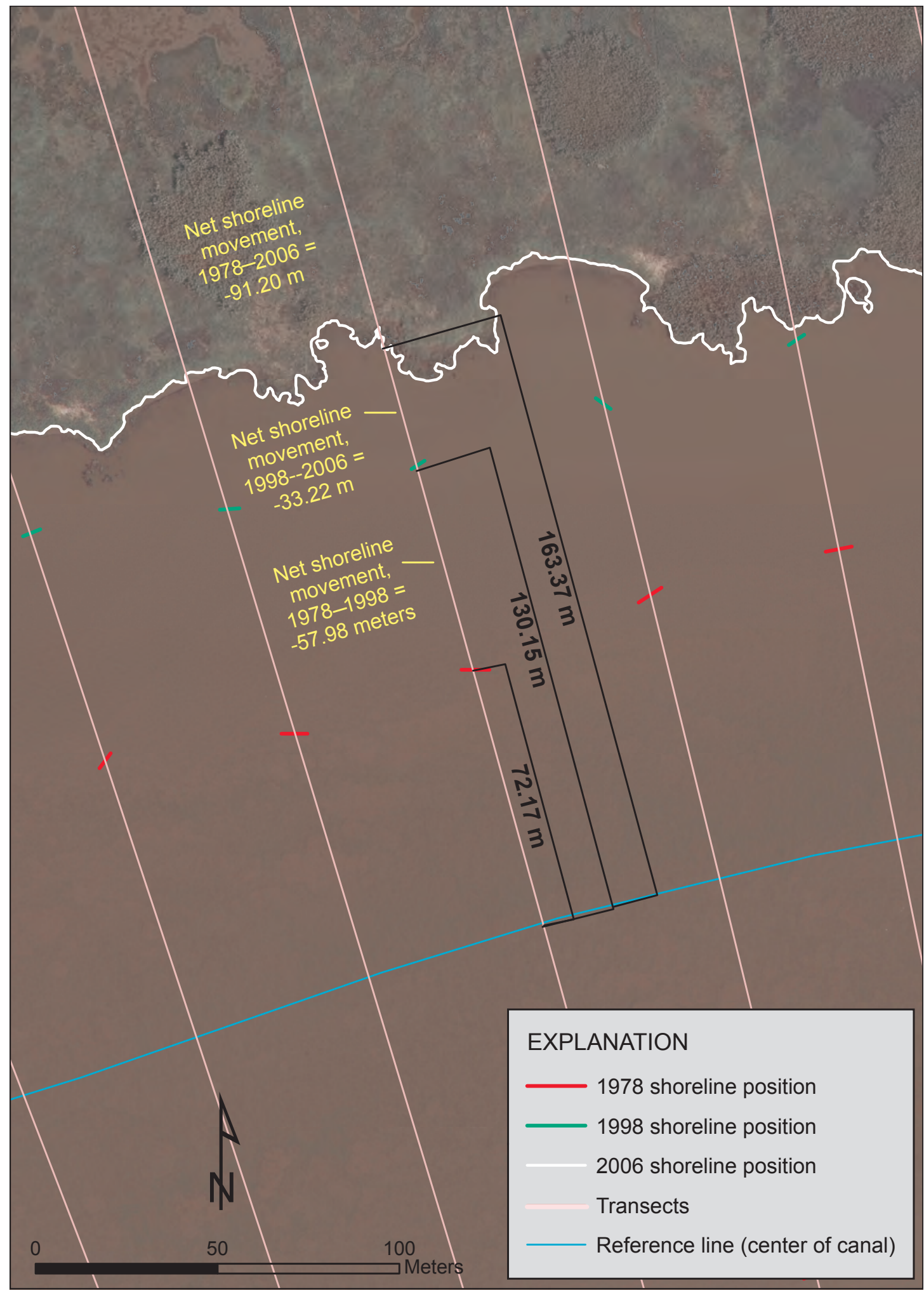

Figure 4. Map showing how net shoreline movement is calculated for each transect to measure erosion rates from 1978-2006 within navigation canals in the northern Gulf of Mexico (limited to the study area). 


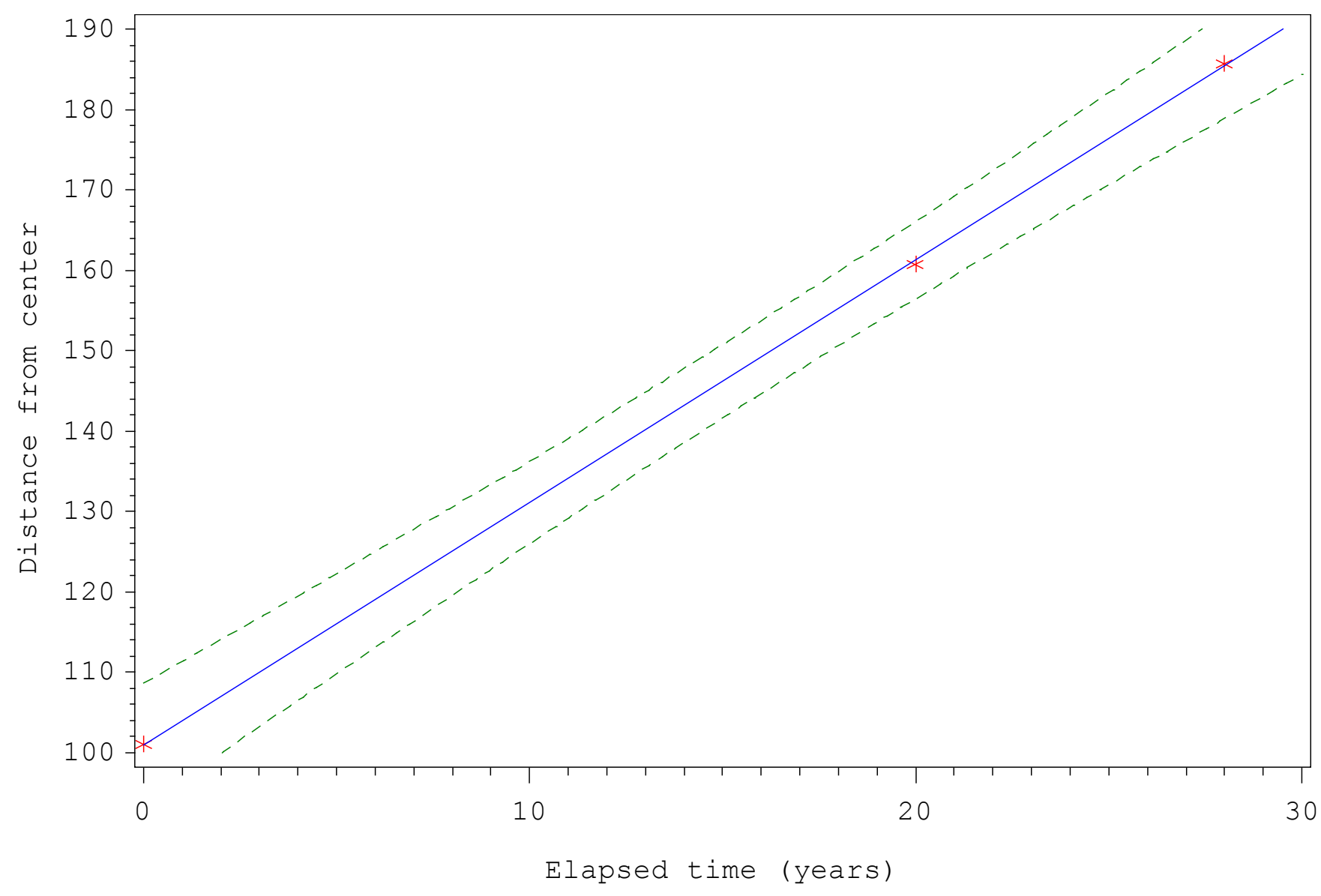

Figure 5. Relationship between canal width (distance from center of canal to east bank) and years elapsed for Transect 1 in the Bayou Lafourche Cutoff canal in Louisiana, 1978-2006. The dotted green line represents the 90 percent confidence interval. Linear regression trendline: $y=3.017 x+100.947$. The slope of the line is the annual erosion rate (that is, $3.017 \mathrm{~m} / \mathrm{year}$ or $9.898 \mathrm{ft} / \mathrm{year}$ ).

widened because of erosion or land loss, while a positive value indicates that a canal has narrowed because of land gain and shoreline advancement. Because of the high degree of variation within individual canals, the minimum, maximum, and standard errors of change rates are reported.

Previous studies have noted that canal widening rates can be influenced by soil characteristics, vessel traffic, salinity, and other factors (Johnson and Gosselink, 1982; Tabberer and others, 1985). For example, the ability of a marsh to recover from the impacts of canal construction and dredging decreases with increases in the percentage of organic content in soil, because organic soils have less resistance to compaction and decomposition (Johnston and others, unpub. data, 2007). In addition, Baumann and Turner (1990) found that canals occurring within some vegetation types may be more susceptible to erosion than others, with the highest erosion rates occurring in salt marsh. Geologic region (for example, chenier plain versus the deltaic plain) can also influence the impact of pipeline or canal construction on wetland loss (Baumann and Turner, 1990).
The percentage of organic content of the canal bank soil was determined from county-level data obtained from the digital Soil Survey Geographic (SSURGO) Database (fig. 6) (Natural Resources Conservation Service, n.d.). The geologic region was identified along each bank by using digital geology data (figs. 7-9), and vegetation type for canals in Louisiana was determined for 1997 and 2007 by using data on marsh vegetation types in coastal Louisiana (Linscombe and others, 1998; Sasser and others, 2008; figs. 10-11). Vessel traffic levels also likely influence erosion rates through the scouring effect of boat wakes on the shoreline (Johnson and Gosselink, 1982); however, sufficient data on vessel traffic, such as the number of trips per year, vessel speed, and vessel size were not available for the navigation canals in the study area (Greg Kozlowski, Minerals Management Service, oral commun.).

An analysis of variance (ANOVA) was performed by using SAS ${ }^{\circledR}$ Version 9.1 (SAS Institute Inc., 2004, Cary, N.C., USA) to separately test for statistical differences in mean shoreline change rates among categorical factors, including canal bank substrate, geologic region, and marsh vegetation 


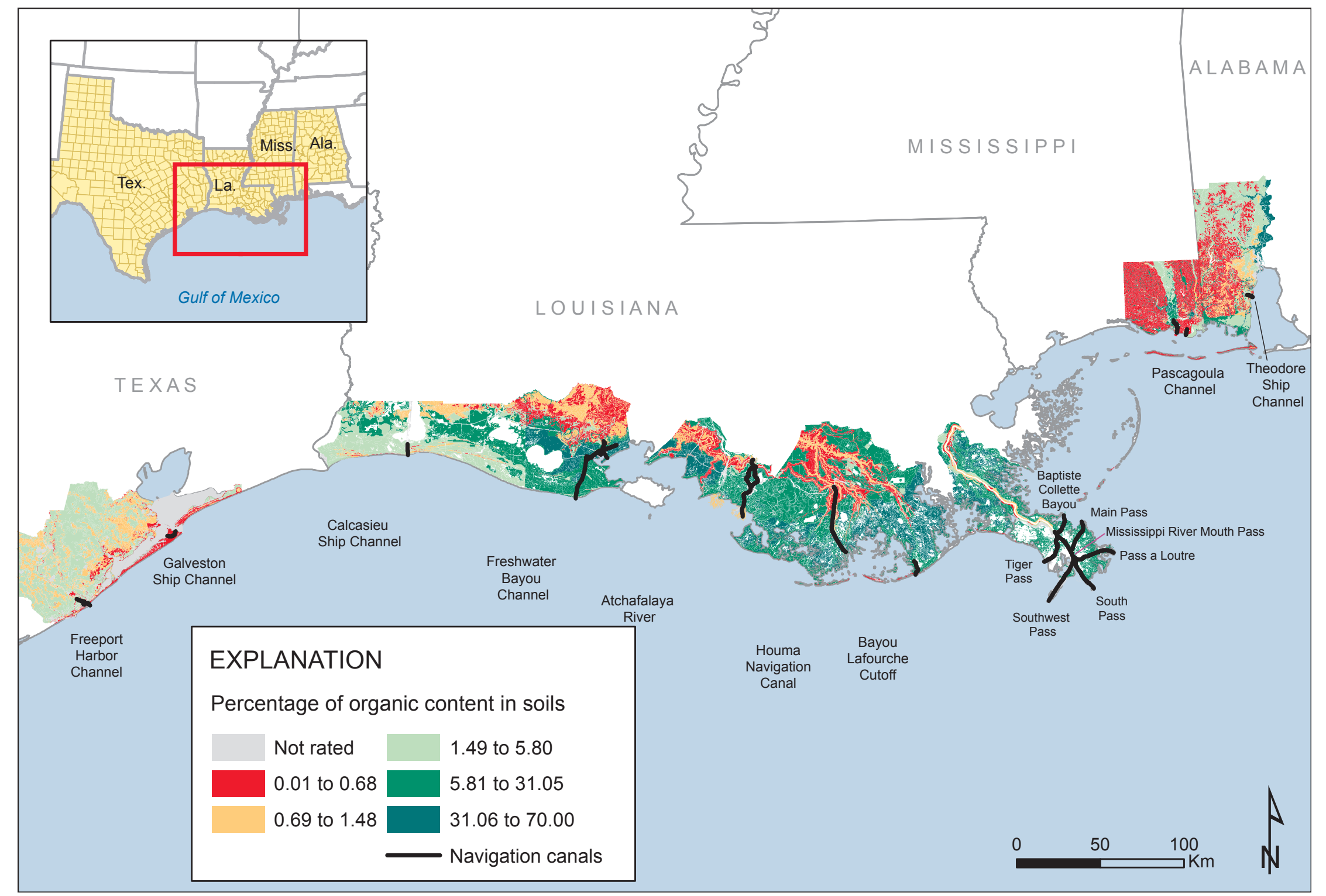

Figure 6. Percentage of organic content of soils surrounding navigation canals selected for this study in the northern Gulf of Mexico, based on soils data from the Soil Survey Geographic Database (SSURG0) (National Resources Conservation Service, n.d.). 


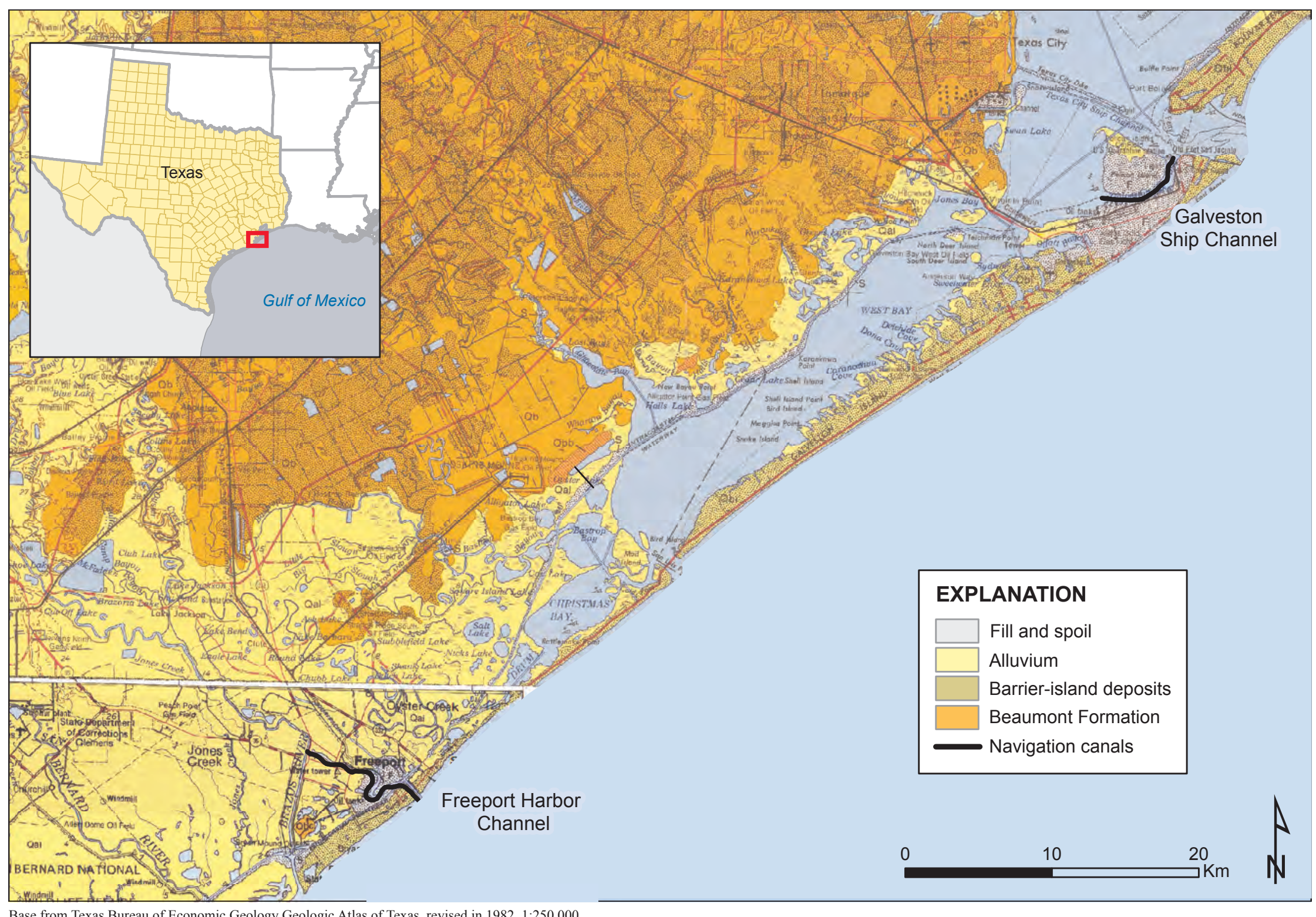

Figure 7. Geology of coastal Texas. 


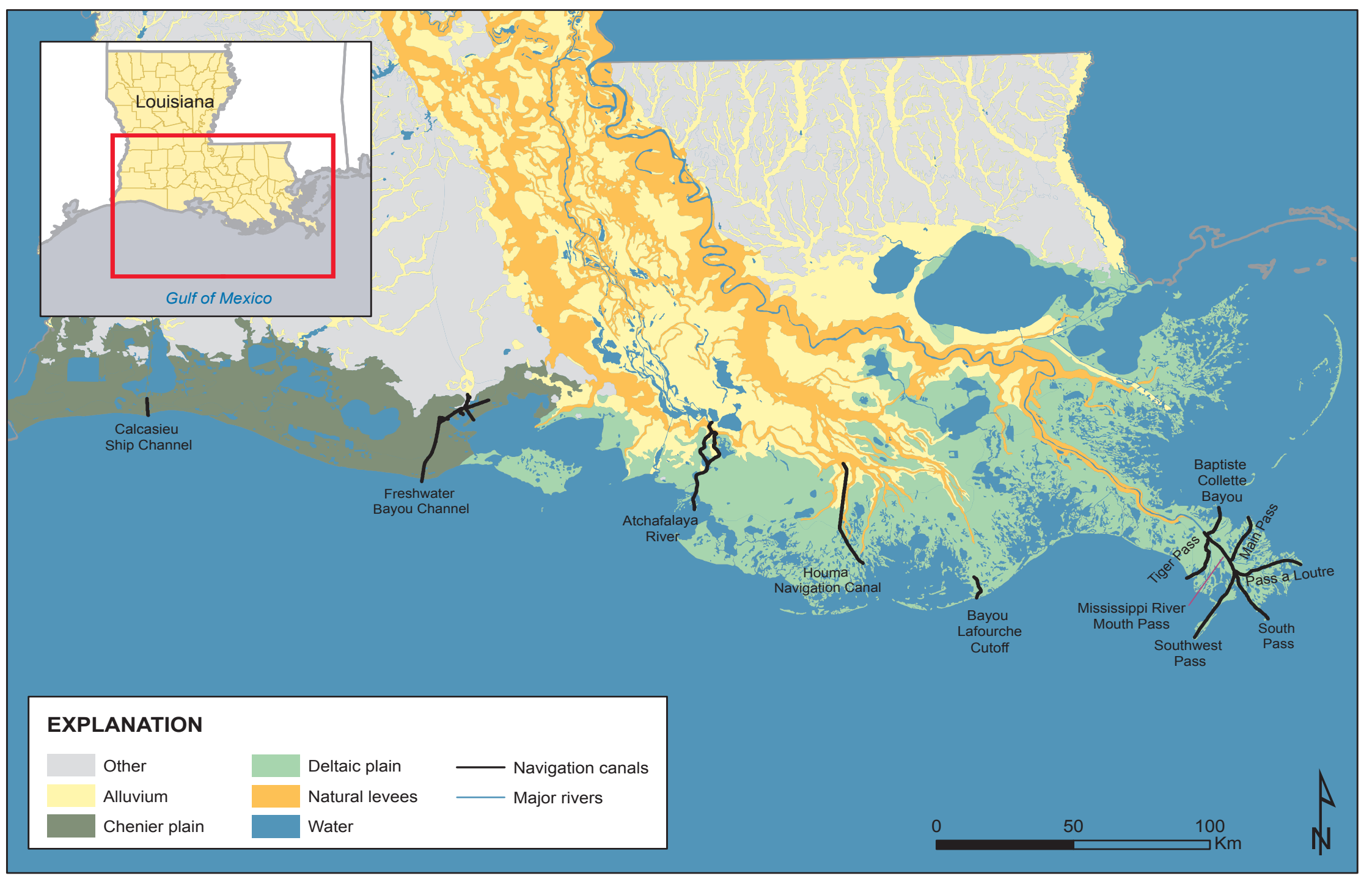

Base from U.S. Geological Survey, National Wetlands Research Center Digital Overlay of the Geologic Map of Louisiana, 1998, 1:500,000

Figure 8. Geology of coastal Louisiana. 


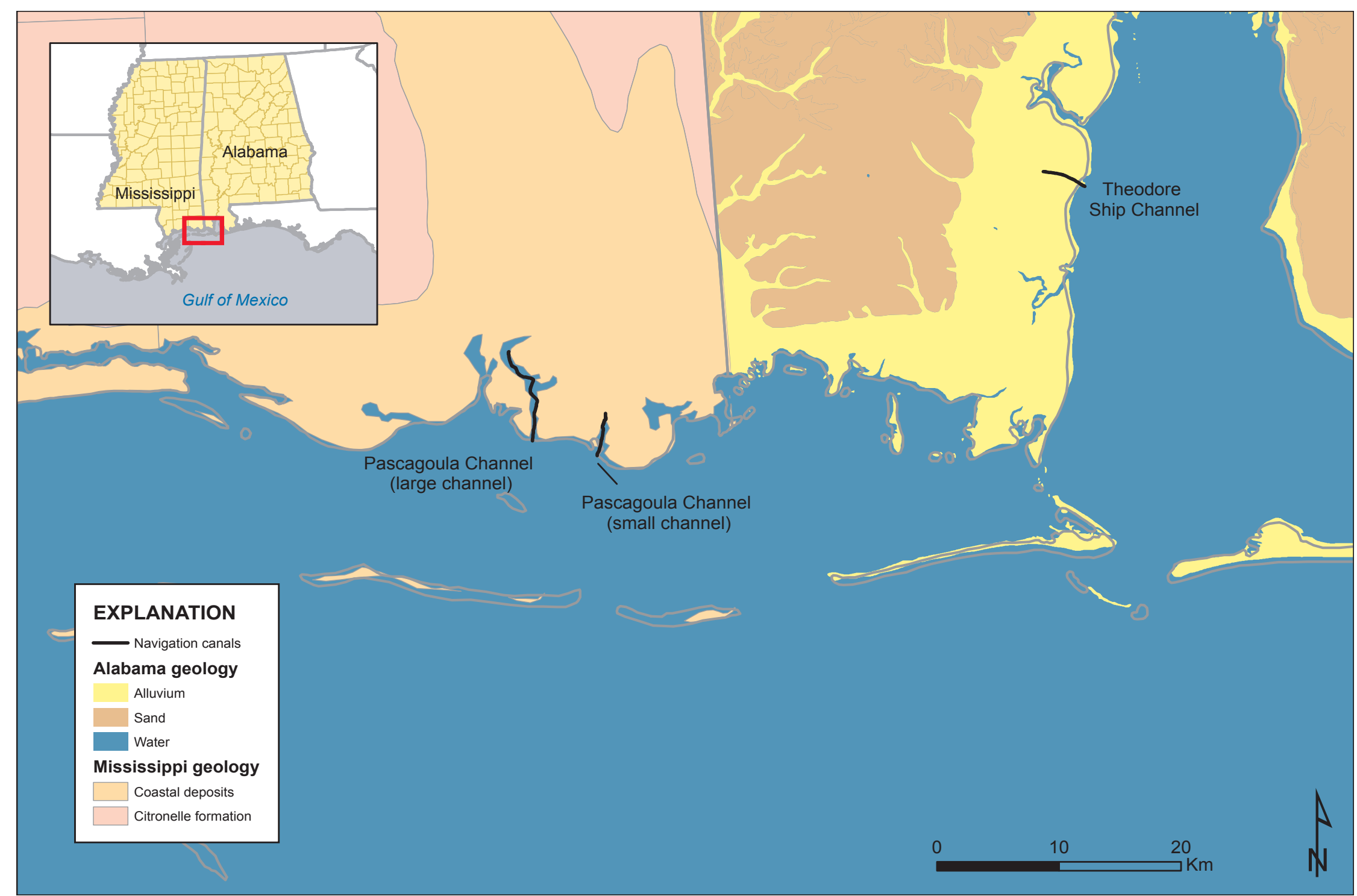

Base modified from Geological Survey of Alabama, Digital Geologic Map for Mobile and Baldwin Counties, Alabama, 1999, 1:250,000 and Mississippi Department of Environmental Quality, Surface Geology, 1969, 1:100,000.

Figure 9. Geology of coastal Mississippi and Alabama. 




Base from U.S. Geological Survey, National Wetlands Research Center USGS-NWRC 1997-02-0132, 1997, 1:550,000

Figure 10. Marsh vegetation types in coastal Louisiana, based on Linscombe and others (1998). 




Base from U.S. Geological Survey Open-File Report 2008-1224, 2008, 1:550,000

Figure 11. Marsh vegetation types in coastal Louisiana, based on Sasser and others (2008). 
type. Linear regression (General Linear Model [GLM] procedure) was used to test for differences in mean shoreline change rates based on soil organic content levels, which was a continuous independent variable. Marsh vegetation data from two different time periods (1997 and 2007) was used in the analysis because marsh vegetation types have changed over the time period of the study. Erosion rates from the 1978/79 to $1996 / 98$ time period were analyzed by using 1997 marsh vegetation data (Linscombe and others, 1997), and 1996/98 to $2005 / 06$ erosion rates were analyzed by using 2007 data (Sasser and others, 2008). The other analyses of differences in mean shoreline change were conducted based on the entire time period of the study (1978-2006).

The individual navigation canals were not an ideal sampling unit because they vary in length from $3.7 \mathrm{~km}$ (Theodore Ship Channel, Ala.) to $58.8 \mathrm{~km}$ (Freshwater Bayou Channel, La.). In addition, the landscape conditions within the canals, particularly the longer ones, had a large degree of variation related to varying salinity levels, proximity to the Gulf of Mexico, vegetation type, and vessel traffic levels. Therefore, to reduce the heterogeneity of landscape conditions within the sampling unit, each canal was separated into $1-\mathrm{km}$ increments; in total (within all 17 navigation canals), there were 365 segments. Samples containing fewer than 5 transects per categorical factor were removed, reducing the sample size to 316 segments $(1-\mathrm{km})$. Finally, mean shoreline change rates were calculated for each categorical factor within each $1-\mathrm{km}$ segment of canal bank.

To meet the assumptions of ANOVA, variables were tested for normality and homogeneity of variance. Because transformations did not normalize the data, Kruskal-Wallis nonparametric ANOVA was used in SAS ${ }^{\circledR}$ to test for significant differences among mean shoreline change rates (NPAR1WAY procedure). Results are reported as mean $\pm \mathrm{SE}$ unless otherwise indicated.

\section{Error Estimation}

Sources of measurement errors include image rectification error and digitizing error. Rectification error is the maximum root mean square (RMS) error allowed during aerial photoregistration. RMS error is a measure of uncertainty in geographic data that is calculated as the square root of the mean squared differences in geographic coordinates between the dataset being rectified and a highly accurate, independent dataset. Digitizing error refers to inaccuracies or uncertainties in the line drawn to represent the canal bank. To quantify this error, randomly selected canal bank sections were digitized three times, and the mean distance between each line was calculated (Price, 2006). This process was completed separately for the 1978/79, 1996/98, and 2005/06 datasets because of differences in pixel resolution and image quality. Errors related to canal bank position were calculated as the square root of the sum of squares of all error sources (Morton and others, 2004). To calculate an annualized error rate $(\mathrm{m} /$ year), an error related to canal bank position was divided by the temporal period of the study (number of years).

\section{Results}

\section{Canal Bank Substrate}

The total length $(\mathrm{m})$ of canal banks by substrate type was measured for selected navigation canals in the northern Gulf of Mexico study area, based on 2005-06 aerial photography (table 3). The shoreline length by substrate was also measured as a straight line along the canal bank, parallel to the canal center line, based on the same photography (table 4). This measurement of shoreline length ignores small bends or inlets along the canal banks (fig. 3) and thus provides a better characterization of the substrate composition of the navigation canals. This length measurement was then used to calculate the percentage of canal bank length within each substrate type (table 5). Combining all canals, we found that almost 64 percent of the navigation canal banks had a vegetated substrate, 19 percent were armored with rock rip-rap, 7 percent were armored with bulkheads (typically concrete), 4 percent were armored with visibly degraded rock rip-rap, 4 percent was open water, and the remaining 2 percent of the canal banks consisted of dredge spoil, sand, and shell.

\section{Shoreline Change Rates}

To measure shoreline change, 11,954 transects were generated at 50-m (164-ft) increments. Once we removed transects located within CWPPRA-funded restoration sites or along canal banks that were clearly impacted by human activities, 11,808 transects remained. The sample size was further reduced to 7,418 transects after some were deleted that were not consistently nonarmored throughout all three time periods.

Results from the linear regression method were that mean annual rates of shoreline change ranged from 1.75 $\mathrm{m} /$ year (5.74 $\mathrm{ft} /$ year) on the west side of the Atchafalaya River, La., where there was shoreline advancement or canal narrowing, to $-3.29 \mathrm{~m} /$ year (-10.79 ft/year) on the south side of the Theodore Ship Channel, Ala., where there was shoreline retreat or erosion (table 6). Note that in the shoreline change measurements, a negative number indicates erosion (shoreline retreat), while a positive number indicates land gain (shoreline advance). When using the EPR method (total shoreline movement divided by the number of years), results related to shoreline change rates were similar to those derived from the linear regression. Canal widening or narrowing rates, calculated by adding shoreline change for each side of the canal together, are also reported for each navigation canal as a whole (table 7). The mean annual rates of total canal widening 
Table 3. Total length (in meters) of canal banks by substrate type within navigation canals in the northern Gulf of Mexico in $2005-06$.

\begin{tabular}{|c|c|c|c|c|c|c|c|c|c|}
\hline & Natural/Negetated & Rock wall & Shell & Sand & Bulkhead & $\begin{array}{c}\text { Dredge } \\
\text { spoil }\end{array}$ & Other & $\begin{array}{l}\text { Degraded } \\
\text { rock wall }\end{array}$ & $\begin{array}{l}\text { Total shoreline } \\
\text { length }\end{array}$ \\
\hline Atchafalaya River, La. & 160,225 & 5,491 & 0 & 312 & 9,324 & 666 & 4 & 0 & 176,022 \\
\hline Baptiste Collette Bayou channel, La. & 52,207 & 5,729 & 0 & 97 & 0 & 0 & 354 & 65 & 58,452 \\
\hline Bayou Lafourche Cutoff, La. & 13,057 & 5,397 & 342 & 2,275 & 4,174 & 0 & 0 & 2,177 & 27,422 \\
\hline Calcasieu Ship Channel, La. & 8,576 & 6,444 & 0 & 577 & 2,775 & 0 & 0 & 0 & 18,372 \\
\hline Freeport Harbor Channel, Tex. & 1,941 & 21,179 & 0 & 1,816 & 8,436 & 0 & 0 & 0 & 33,372 \\
\hline Freshwater Bayou Channel, La. & 138,448 & 21,277 & 0 & 1,024 & 14,045 & 4,524 & 6,886 & 5,024 & 191,228 \\
\hline Galveston Ship Channel, Tex. & 1,696 & 5,410 & 0 & 2,471 & 25,737 & 0 & 140 & 0 & 35,454 \\
\hline Houma Navigation Canal, La. & 128,228 & 12,433 & 909 & 84 & 18,697 & 0 & 747 & 127 & 161,225 \\
\hline Main Pass channel, La. & 56,211 & 601 & 0 & 274 & 827 & 0 & 176 & 0 & 58,089 \\
\hline Mississippi River Mouth Pass, La. & 14,395 & 25,234 & 0 & 131 & 2,422 & 0 & 1,031 & 4,553 & 47,766 \\
\hline Pascagoula Channel, Miss. (large channel) & 13,697 & 7,227 & 0 & 4,689 & 5,196 & 1,656 & 0 & 0 & 32,465 \\
\hline Pascagoula Channel, Miss. (small channel) & 3,049 & 1,733 & 140 & 3,268 & 5,082 & 0 & 130 & 0 & 13,402 \\
\hline Pass a Loutre channel, La. & 74,116 & 588 & 0 & 0 & 701 & 0 & 1,890 & 0 & 77,295 \\
\hline South Pass channel, La. & 56,663 & 1,012 & 0 & 0 & 118 & 0 & 474 & 91 & 58,358 \\
\hline Southwest Pass channel, La. & 10,619 & 36,206 & 0 & 187 & 24 & 0 & 75 & 26,365 & 73,476 \\
\hline Theodore Ship Channel, Ala. & 5,842 & 878 & 0 & 814 & 4,440 & 0 & 0 & 0 & 11,974 \\
\hline Tiger Pass channel, La. & 51,276 & 2,403 & 0 & 153 & 6,347 & 0 & 888 & 227 & 61,294 \\
\hline
\end{tabular}


Table 4. Linear length of canals by substrate type, measured in 50-m increments from the canal center line within navigation canals in the northern Gulf of Mexico in $2005-06$.

Main Pass channel, La.

Main Pass channel, La.

Mississippi River Mouth Pass La.

Mississippi River Mouth Pass, La.

Pascagoula Channel, Miss. (large)

Natural/

Rock

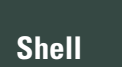

Sand

Bulkhead

Dredge
spoil

Water

Other

Degraded

Atchafalaya River, La.

48,350

1,300

0

100

3,650

spoil

1,100

47,450

2,700

Baptiste Collette Bayou, La.

East

9,950

1,750

0

$0 \quad 3,400$

West

8,950

2,800

Bayou Lafourche Cutoff, La.

East

Bayou Lafourche Cutoff, La.

West

4,650

50

3,900

5,100

East

3,350

1,900

West

2,550

3,150

North

Freeport Harbor Channel, Tex.

South

Freshwater Bayou Channel, La.

N \& S

0

9,700

$350 \quad 8,000$

$\mathrm{N} \& \mathrm{~S}$

49,550

7,950

$47,300 \quad 10,950$

North

South

West

East

East

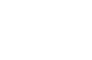

0

$0 \quad 0$

(1)

$\begin{array}{ll}150 & 1,100 \\ 0 & 1,000 \\ 0 & \end{array}$

rip-ra

Total

Galveston Ship Channel, Tex.

$$
1,700
$$

850

31,550

1,150

35,200

7,700

17,900

West

17,150

1,900

$$
4,750
$$$$
550
$$$$
150
$$

11,250

West

12,700

$4,100 \quad 2,300$

$3,200 \quad 1,150$

Pascagoula Channel, Miss. (large)

East

Pascagoula Channel, Miss. (small)

East

1,400

150

Pascagoula Channel, Miss. (small) West

400

50

100

$\begin{array}{rr}50 & 0 \\ 1,850 & 2,450\end{array}$

0

950
800

0
0

$0 \quad 54,650$

(0

(1)

400

250

350

0

0

0

0
0
0
0
0
0
0
0
50

$0 \quad 54,550$

$0 \quad 12,650$

$50 \quad 12,650$

$0 \quad 9,500$

$150 \quad 9,500$

$0 \quad 6,700$

$0 \quad 6,700$

$0 \quad 11,700$

$0 \quad 11,700$

$700 \quad 65,050$

$4,300 \quad 65,250$

$\begin{array}{rrr}0 & 0 & 600 \\ 0 & 100 & 5,400\end{array}$

150

$$
750
$$

1,200

6,400

$\begin{array}{rrr}0 & 100 & 5,400 \\ 1,250 & 0 & 2,100\end{array}$

(0)

0

0

6,200

42,200

40,900

19,200

19,050

18,750

18,900

8,900

8,700

3,800

3,550 
Table 4. Linear length of canals by substrate type, measured in 50-m increments from the canal center line within navigation canals in the northern Gulf of Mexico in 2005-06-Continued.

\begin{tabular}{|c|c|c|c|c|c|c|c|c|c|c|c|}
\hline & Side & $\begin{array}{c}\text { Natural/ } \\
\text { Vegetated }\end{array}$ & $\begin{array}{c}\text { Rock } \\
\text { rip-rap }\end{array}$ & Shell & Sand & Bulkhead & $\begin{array}{c}\text { Dredge } \\
\text { spoil }\end{array}$ & Water & Other & $\begin{array}{l}\text { Degraded } \\
\text { rock } \\
\text { rip-rap }\end{array}$ & $\begin{array}{c}\text { Total } \\
\text { length }\end{array}$ \\
\hline Pass a Loutre channel, La. & North & 19,600 & 50 & 0 & 0 & 50 & 0 & 1,750 & 450 & 0 & 21,900 \\
\hline Pass a Loutre channel, La. & South & 18,700 & 500 & 0 & 0 & 0 & 0 & 1,100 & 600 & 0 & 20,900 \\
\hline South Pass channel, La. & East & 17,900 & 400 & 0 & 0 & 0 & 0 & 2,950 & 0 & 100 & 21,350 \\
\hline South Pass channel, La. & West & 19,350 & 450 & 0 & 0 & 0 & 0 & 1,050 & 250 & 0 & 21,100 \\
\hline Southwest Pass channel, La. & East & 1,250 & 17,850 & 0 & 150 & 50 & 0 & 750 & 50 & 9,600 & 29,700 \\
\hline Southwest Pass channel, La. & West & 2,100 & 17,550 & 0 & 0 & 0 & 0 & 150 & 0 & 10,200 & 30,000 \\
\hline Theodore Ship Channel, Ala. & North & 900 & 600 & 0 & 300 & 1,600 & 0 & 0 & 0 & 0 & 3,400 \\
\hline Theodore Ship Channel, Ala. & South & 1,100 & 0 & 0 & 200 & 1,500 & 0 & 0 & 0 & 0 & 2,800 \\
\hline Tiger Pass channel, La. & East & 9,200 & 650 & 0 & 0 & 0 & 0 & 5,600 & 150 & 0 & 15,600 \\
\hline Tiger Pass channel, La. & West & 11,050 & 500 & 0 & 100 & 2,450 & 0 & 1,750 & 50 & 250 & 16,150 \\
\hline
\end{tabular}


Table 5. Percent of canals in each bank substrate type, calculated from the linear length of canal banks within navigation canals in the northern Gulf of Mexico in $2005-06$.

\begin{tabular}{|c|c|c|c|c|c|c|c|c|c|c|}
\hline & Side & $\begin{array}{c}\text { Natural/ } \\
\text { Vegetated }\end{array}$ & $\begin{array}{l}\text { Rock rip- } \\
\text { rap }\end{array}$ & Shell & Sand & Bulkhead & $\begin{array}{l}\text { Dredge } \\
\text { spoil }\end{array}$ & Water & Other & $\begin{array}{c}\text { Degraded rock } \\
\text { rip-rap }\end{array}$ \\
\hline Atchafalaya River, La. & East & 88.5 & 2.4 & 0.0 & 0.2 & 6.7 & 0.3 & 2.0 & 0.0 & 0.0 \\
\hline Atchafalaya River, La. & West & 87.0 & 4.9 & 0.0 & 0.0 & 6.2 & 0.0 & 1.8 & 0.0 & 0.0 \\
\hline Baptiste Collette Bayou channel, La. & East & 78.7 & 13.8 & 0.0 & 0.0 & 0.0 & 0.0 & 7.5 & 0.0 & 0.0 \\
\hline Baptiste Collette Bayou channel, La. & West & 70.8 & 22.1 & 0.0 & 0.4 & 0.0 & 0.0 & 6.3 & 0.0 & 0.4 \\
\hline Bayou Lafourche Cutoff, La. & East & 48.9 & 0.5 & 1.1 & 19.5 & 25.8 & 0.0 & 4.2 & 0.0 & 0.0 \\
\hline Bayou Lafourche Cutoff, La. & West & 41.1 & 53.7 & 0.0 & 1.1 & 0.0 & 0.0 & 2.6 & 0.0 & 1.6 \\
\hline Calcasieu Ship Channel, La. & East & 50.0 & 28.4 & 0.0 & 1.5 & 14.9 & 0.0 & 5.2 & 0.0 & 0.0 \\
\hline Calcasieu Ship Channel, La. & West & 38.1 & 47.0 & 0.0 & 0.7 & 14.2 & 0.0 & 0.0 & 0.0 & 0.0 \\
\hline Freeport Harbor Channel, Tex. & North & 0.0 & 82.9 & 0.0 & 4.7 & 12.4 & 0.0 & 0.0 & 0.0 & 0.0 \\
\hline Freeport Harbor Channel, Tex. & South & 3.0 & 68.4 & 0.0 & 6.4 & 20.9 & 0.0 & 1.3 & 0.0 & 0.0 \\
\hline Freshwater Bayou Channel, La. & $\mathrm{N} \& \mathrm{~S}$ & 76.2 & 12.2 & 0.0 & 1.1 & 7.5 & 0.5 & 1.4 & 0.1 & 1.1 \\
\hline Freshwater Bayou Channel, La. & $N \& S$ & 72.5 & 16.8 & 0.0 & 0.0 & 0.9 & 0.2 & 1.1 & 1.8 & 6.6 \\
\hline Galveston Ship Channel, Tex. & North & 0.0 & 13.3 & 0.0 & 1.6 & 84.4 & 0.0 & 0.0 & 0.8 & 0.0 \\
\hline Galveston Ship Channel, Tex. & South & 27.4 & 18.5 & 20.2 & 0.0 & 33.9 & 0.0 & 0.0 & 0.0 & 0.0 \\
\hline Houma Navigation Canal, La. & West & 74.8 & 18.2 & 0.0 & 0.0 & 4.1 & 0.0 & 2.7 & 0.1 & 0.0 \\
\hline Houma Navigation Canal, La. & East & 86.1 & 4.6 & 0.0 & 0.0 & 6.6 & 0.0 & 2.6 & 0.1 & 0.0 \\
\hline Main Pass channel, La. & East & 93.2 & 0.0 & 0.0 & 1.3 & 0.0 & 0.0 & 5.5 & 0.0 & 0.0 \\
\hline Main Pass channel, La. & West & 90.0 & 2.9 & 0.0 & 0.0 & 0.0 & 0.0 & 7.1 & 0.0 & 0.0 \\
\hline Mississippi River Mouth Pass, La. & East & 25.3 & 60.0 & 0.0 & 0.0 & 5.3 & 0.0 & 7.2 & 0.0 & 2.1 \\
\hline Mississippi River Mouth Pass, La. & West & 0.8 & 67.2 & 0.0 & 0.0 & 12.4 & 0.0 & 1.6 & 0.5 & 17.5 \\
\hline Pascagoula Channel, Miss. large & East & 46.1 & 25.8 & 0.0 & 5.6 & 7.3 & 9.0 & 6.2 & 0.0 & 0.0 \\
\hline Pascagoula Channel, Miss. large & West & 36.8 & 13.2 & 0.0 & 18.4 & 28.7 & 0.0 & 2.9 & 0.0 & 0.0 \\
\hline Pascagoula Channel, Miss. small & East & 36.8 & 3.9 & 0.0 & 14.5 & 43.4 & 0.0 & 1.3 & 0.0 & 0.0 \\
\hline Pascagoula Channel, Miss. small & West & 11.3 & 1.4 & 4.2 & 32.4 & 50.7 & 0.0 & 0.0 & 0.0 & 0.0 \\
\hline Pass a Loutre channel, La. & North & 89.5 & 0.2 & 0.0 & 0.0 & 0.2 & 0.0 & 8.0 & 2.1 & 0.0 \\
\hline Pass a Loutre channel, La. & South & 89.5 & 2.4 & 0.0 & 0.0 & 0.0 & 0.0 & 5.3 & 2.9 & 0.0 \\
\hline
\end{tabular}


Table 5. Percent of canals in each bank substrate type, calculated from the linear length of canal banks within navigation canals in the northern Gulf of Mexico in 2005-06Continued.

\begin{tabular}{|c|c|c|c|c|c|c|c|c|c|c|}
\hline & Side & $\begin{array}{c}\text { Natural/ } \\
\text { Vegetated }\end{array}$ & $\begin{array}{l}\text { Rock rip- } \\
\text { rap }\end{array}$ & Shell & Sand & Bulkhead & $\begin{array}{c}\text { Dredge } \\
\text { spoil }\end{array}$ & Water & Other & $\begin{array}{l}\text { Degraded rock } \\
\text { rip-rap }\end{array}$ \\
\hline South Pass channel, La. & East & 83.8 & 1.9 & 0.0 & 0.0 & 0.0 & 0.0 & 13.8 & 0.0 & 0.5 \\
\hline South Pass channel, La. & West & 91.7 & 2.1 & 0.0 & 0.0 & 0.0 & 0.0 & 5.0 & 1.2 & 0.0 \\
\hline Southwest Pass channel, La. & East & 4.2 & 60.1 & 0.0 & 0.5 & 0.2 & 0.0 & 2.5 & 0.2 & 32.3 \\
\hline Southwest Pass channel, La. & West & 7.0 & 58.5 & 0.0 & 0.0 & 0.0 & 0.0 & 0.5 & 0.0 & 34.0 \\
\hline Theodore Ship Channel, Ala. & North & 26.5 & 17.6 & 0.0 & 8.8 & 47.1 & 0.0 & 0.0 & 0.0 & 0.0 \\
\hline Theodore Ship Channel, Ala. & South & 39.3 & 0.0 & 0.0 & 7.1 & 53.6 & 0.0 & 0.0 & 0.0 & 0.0 \\
\hline Tiger Pass channel, La. & East & 59.0 & 4.2 & 0.0 & 0.0 & 0.0 & 0.0 & 35.9 & 1.0 & 0.0 \\
\hline Tiger Pass channel, La. & West & 68.4 & 3.1 & 0.0 & 0.6 & 15.2 & 0.0 & 10.8 & 0.3 & 1.5 \\
\hline
\end{tabular}


Table 6. Mean erosion rate (meters per year) for nonarmored portions of navigation canals in the northern Gulf of Mexico, 1978-2006, based on linear regression calculations. Values are provided separately for each side of the canal. Negative values refer to shoreline retreat (erosion or canal widening), while positive values refer to shoreline advance (canal narrowing).

[N, number of transects in sample; SE, standard error; Min, minimum; Max, maximum]

\begin{tabular}{|c|c|c|c|c|c|c|}
\hline Name & Side & $\mathbf{N}$ & Mean & SE & Min & Max \\
\hline Atchafalaya River, La. & West & 768 & 1.75 & 0.20 & -9.8 & 29.32 \\
\hline Baptiste Collette Bayou channel, La. & North & 164 & -3.14 & 0.08 & -6.49 & -0.08 \\
\hline Baptiste Collette Bayou channel, La. & South & 179 & -3.20 & 0.11 & -9.92 & 0.46 \\
\hline Bayou Lafourche Cutoff, La. & West & 65 & -1.46 & 0.10 & -3.51 & -0.09 \\
\hline Calcasieu Ship Channel, La. & East & 48 & -1.45 & 0.13 & -3.77 & 2.4 \\
\hline Calcasieu Ship Channel, La. & West & 27 & -0.79 & 0.08 & -1.75 & -0.3 \\
\hline Freshwater Bayou Channel, La. & $\mathrm{E} \& \mathrm{~W}$ & 580 & -1.27 & 0.07 & -8.02 & 24.26 \\
\hline Galveston Ship Channel, Tex. & South & $<5$ & . & . & . & . \\
\hline Galveston Ship Channel, Tex & North & 5 & 0.85 & 0.36 & 0.01 & 2.15 \\
\hline Houma Navigation Canal, La. & East & 697 & -1.41 & 0.04 & -7.88 & 3.03 \\
\hline Houma Navigation Canal, La. & West & 592 & -1.56 & 0.08 & -19.38 & 0.42 \\
\hline Main Pass channel, La. & East & 263 & 0.93 & 0.06 & -3.19 & 2.73 \\
\hline Main Pass channel, La. & West & 258 & 0.69 & 0.09 & -6.14 & 6.35 \\
\hline Pascagoula Channel, Miss (small channel) & East & 29 & -0.42 & 0.16 & -4.41 & 0.69 \\
\hline Pascagoula Channel, Miss (small channel) & West & 28 & -0.45 & 0.40 & -10.13 & 1.22 \\
\hline Pass a Loutre channel, La. & North & 352 & 1.04 & 0.09 & -4.29 & 8.28 \\
\hline Pass a Loutre channel, La. & South & 317 & 0.71 & 0.14 & -4.66 & 15.47 \\
\hline South Pass channel, La. & East & 373 & 0.09 & 0.05 & -2.79 & 3.2 \\
\hline South Pass channel, La. & West & 378 & -0.10 & 0.06 & -5.69 & 4.76 \\
\hline Southwest Pass channel, La. & East & $<5$ & . & . & . & . \\
\hline Southwest Pass channel, La. & West & $<5$ & . & . & . & . \\
\hline Theodore Ship Channel, Ala. & North & 12 & -3.19 & 0.88 & -8.13 & -0.09 \\
\hline Theodore Ship Channel, Ala. & South & 19 & -3.29 & 0.25 & -5.91 & -0.03 \\
\hline Tiger Pass channel, La. & East & 136 & -2.10 & 0.20 & -12.98 & 2.78 \\
\hline Tiger Pass channel, La. & West & 206 & -2.21 & 0.10 & -7.75 & 0.57 \\
\hline
\end{tabular}


Table 7. Mean annual change in canal width (meters per year) for nonarmored portions of navigation canals in the northern Gulf of Mexico, 1978-2006, based on linear regression calculations. Negative values refer to shoreline retreat (erosion or canal widening), while positive values refer to shoreline advance (canal narrowing).

[SE, standard error]

\begin{tabular}{|c|c|c|}
\hline me & Mean & SE \\
\hline Atchafalaya River, La. & 2.58 & 0.21 \\
\hline $\begin{array}{l}\text { Baptiste Collette Bayou channel, } \\
\text { La. }\end{array}$ & -6.34 & 0.10 \\
\hline Calcasieu Ship Channel, La. & -2.24 & 0.11 \\
\hline Freeport Harbor Channel, Tex. & 0.20 & 0.13 \\
\hline Freshwater Bayou Channel, La. & -2.69 & 0.06 \\
\hline Galveston Ship Channel, Tex. & 0.85 & 0.36 \\
\hline Houma Navigation Canal, La. & -2.97 & 0.06 \\
\hline Bayou Lafourche Cutoff, La. & -2.48 & 0.12 \\
\hline Main Pass channel, La. & 1.62 & 0.07 \\
\hline Mississippi River Mouth Pass, La. & -2.72 & 0.35 \\
\hline $\begin{array}{l}\text { Pascagoula Channel, Miss. (large } \\
\text { channel) }\end{array}$ & -0.76 & 0.08 \\
\hline $\begin{array}{l}\text { Pascagoula Channel, Miss. (small } \\
\text { channel) }\end{array}$ & -0.88 & 0.28 \\
\hline Pass a Loutre channel, La. & 1.75 & 0.12 \\
\hline South Pass channel, La. & -0.01 & 0.06 \\
\hline Southwest Pass channel, La. & · & . \\
\hline Theodore Ship Channel, Ala. & -6.47 & 0.56 \\
\hline Tiger Pass channel, La. & -4.30 & 0.15 \\
\hline
\end{tabular}

or narrowing ranged from $-6.47 \mathrm{~m} /$ year $(-21.23 \mathrm{ft} /$ year) (measured as shoreline retreat) for the Theodore Ship Channel, Ala., to $2.58 \mathrm{~m} /$ year ( $8.46 \mathrm{ft} /$ year) for the Atchafalaya River, La. (measured as shoreline advancement) (table 7).

Rates of shoreline change per navigation canal are shown in the figures included in appendix 2.

\section{Statistical Analysis}

The rate of change in total canal width differed significantly by geologic region $(F=3.09, P=0.03)$. Mean rates of canal widening (erosion; table 8 ) were highest in the chenier plain $(-3.46 \mathrm{~m} /$ year, $\mathrm{SE}=0.41 \mathrm{~m}[-11.35 \mathrm{ft} / \mathrm{year}$, $\mathrm{SE}=1.34 \mathrm{ft}])$ and lowest in the alluvium geologic region $(0.27$ $\mathrm{m} /$ year, $\mathrm{SE}=1.03 \mathrm{~m}[0.88 \mathrm{ft} /$ year, $\mathrm{SE}=3.38 \mathrm{ft}]$ ). Mean canal widening rates were significantly higher in the chenier plain as compared to the deltaic plain, natural levees, or alluvium geologic regions.
Significant differences in shoreline retreat were also found according to marsh vegetation type (tables 9 and 10) for canals in Louisiana during the 1978/79 to 1996/98 time period $(\mathrm{F}=5.91, \mathrm{P}=0.01)$ and during the $1996 / 98$ to $2005 / 06$ time period $(\mathrm{F}=3.40, \mathrm{P}=0.01)$.In the earlier time period, mean canal widening rates were highest in brackish marsh

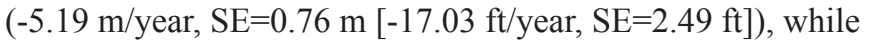
portions of canals in fresh marsh exhibited very little change overall $(0.57 \mathrm{~m} /$ year, $\mathrm{SE}=0.73 \mathrm{~m}[1.87 \mathrm{ft} /$ year, $\mathrm{SE}=2.40$ $\mathrm{ft}]$ ). Mean canal widening rates were significantly higher in brackish marsh compared to fresh marsh, intermediate marsh, and "other" vegetation types (table 9). Mean rates of canal widening were also significantly higher in salt marsh compared to fresh marsh and "other" vegetation types. Finally, mean rates of canal widening were significantly higher in intermediate marsh than in "other" vegetation types. In the $1996 / 98$ to 2005/06 time period, mean rates of canal widening were highest in brackish marsh $(-2.94 \mathrm{~m} /$ year, $\mathrm{SE}=0.49 \mathrm{~m}$ $[-9.65 \mathrm{ft} /$ year, $\mathrm{SE}=1.61 \mathrm{ft}])$ and salt marsh $(-3.16 \mathrm{~m} /$ year, $\mathrm{SE}=0.73 \mathrm{~m}[-10.37 \mathrm{ft} / \mathrm{year}, \mathrm{SE}=2.40 \mathrm{ft}])$ and lowest in fresh marsh, where canals exhibited an overall narrowing in canal width $(3.83 \mathrm{~m} /$ year, $\mathrm{SE}=1.88 \mathrm{~m}$ [12.57 ft/year, $\mathrm{SE}=6.17 \mathrm{ft}])$ (table 10). Mean rates of canal widening were significantly higher in salt marsh and brackish marsh compared to fresh marsh, swamp, and "other" vegetation types. There were also significantly higher canal widening rates in intermediate marsh than in swamp and "other" vegetation types. No significant differences in erosion rates were found among types of canal bank substrate (table 11).

Analysis of the soils data indicated that erosion rates increased slightly as percentage of organic content in the canal bank soil increased $\left(\mathrm{F}_{176}=5.28, P=0.02\right)$. Although a statistically significant relationship existed, the correlation coefficient $\left(R^{2}\right)$ for the linear regression model was only 0.03 , signifying only a weak ecological relationship between erosion rates and percentage of organic content.

\section{Error and Data Limitations}

The annualized error rate (RMS and digitizing errors) for measuring shoreline position (table 12), based on the aerial photography from three different time periods (1978/79, $1996 / 98$, and $2005 / 06)$, was $\pm 0.28 \mathrm{~m} /$ year $( \pm 0.91 \mathrm{ft})$. Although the 1998 imagery has a low RMS error overall, individual frames have errors in image registration that can be as high as $\pm 10 \mathrm{~m}$, affecting horizontal positional accuracy. In addition, some of the 2006 aerial photographs have poor tonal contrast that made it difficult to determine shoreline position in a few isolated areas in the Mississippi deltaic plain region.

Shoreline change rates had a large degree of variability both within and among canals; therefore, shoreline change rates at specific locations can be much different than the mean rates reported for that canal (fig. 12). The substrate type of a canal bank was sometimes difficult to determine, and a field survey of the Houma Navigation Canal, La., indicated that 
Table 8. Mean annual change in canal width (meters per year) for nonarmored portions of navigation canals in the northern Gulf of Mexico, 1978-2006, based on geologic region.

$[\mathrm{N}$, number of transects in sample; SE, standard error $]$

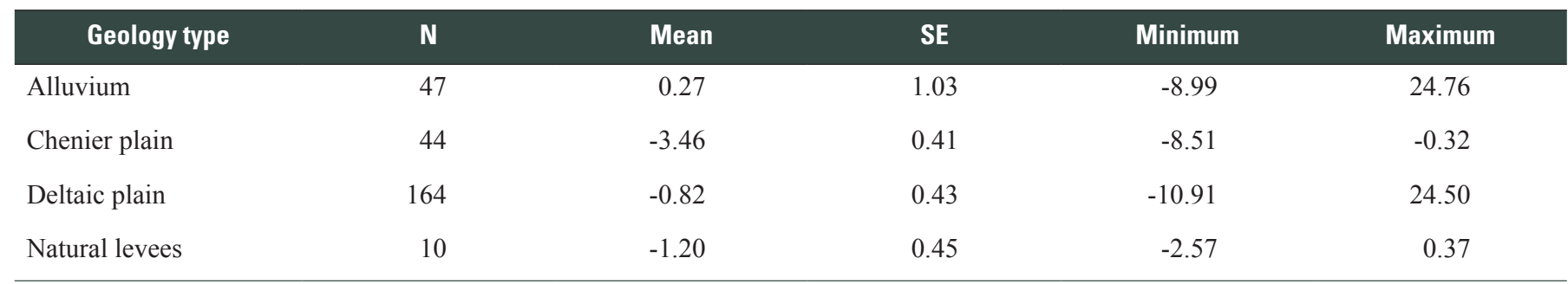

Table 9. Mean annual change in canal width (meters per year) for nonarmored portions of navigation canals in the northern Gulf of Mexico, 1978/79-1996/98, based on vegetation type.

$[\mathrm{N}$, number of transects in sample; SE, standard error $]$

\begin{tabular}{lccccc}
\multicolumn{1}{c}{ Vegetation type } & N & Mean & SE & Minimum & Maximum \\
Fresh marsh & 123 & 0.57 & 0.73 & -11.9 & 39.73 \\
Intermediate marsh & 66 & -2.56 & 0.41 & -9.52 & -12.224 \\
Brackish marsh & 14 & -5.19 & -4.11 & 0.76 & -7.47 \\
Salt marsh & 20 & -1.29 & 0.17 & -2.61 & -1.77 \\
Other & 43 & & & 0.66 \\
\hline
\end{tabular}

Table 10. Mean annual change in canal width (meters per year) for nonarmored portions of navigation canals in the northern Gulf of Mexico, 1996/98-2005/06, based on vegetation type.

$[\mathrm{N}$, number of transects in sample; SE, standard error $]$

\begin{tabular}{|c|c|c|c|c|c|}
\hline Vegetation type & $\mathbf{N}$ & Mean & SE & Minimum & Maximum \\
\hline Fresh marsh & 94 & 3.83 & 1.88 & -53.08 & 80.71 \\
\hline Intermediate marsh & 84 & -1.7 & 0.48 & -22.6 & 4.74 \\
\hline Brackish marsh & 20 & -2.94 & 0.49 & -6.22 & -0.44 \\
\hline Other & 21 & -0.8 & 0.48 & -4.2 & 1.1 \\
\hline
\end{tabular}

Table 11. Mean annual change in canal width (meters per year) for nonarmored portions of navigation canals in the northern Gulf of Mexico, 1978-2006, based on substrate type.

$[\mathrm{N}$, number of transects in sample; SE, standard error $]$

\begin{tabular}{lccccc}
\multicolumn{1}{r}{ Substrate } & N & Mean & SE & \multicolumn{2}{c}{ Minimum } \\
Vegetated & 247 & -1.03 & 0.35 & -11.11 & 24.76 \\
Shell & 1 & -1.07 & - & -1.07 & -1.07 \\
Sand & 10 & -4.53 & 1.12 & -9.29 & -1.56 \\
Other & 9 & -1.03 & 1.10 & -5.43 & 5.22 \\
\hline
\end{tabular}


Table 12. Estimated measurement errors (meters) for determining shoreline position in navigation canals in the northern Gulf of Mexico, 1978-2006.

[N, number of tr ansects in sample; SE, standard error]

\begin{tabular}{lccc} 
& \multicolumn{3}{c}{ Time period } \\
\cline { 2 - 4 } Measurement errors & $\mathbf{1 9 7 8}$ & $\mathbf{1 9 9 6 - 1 9 9 8}$ & $\mathbf{2 0 0 5 - 2 0 0 6}$ \\
Rectification error & 2.2 & 2.5 & 2.7 \\
Digitizing error & 0.9 & 1 & 0.8 \\
\hline
\end{tabular}

some errors were made. For example, oyster shell banks have a very high reflectance, resulting in the mislabeling of the bank substrate as concrete bulkhead. In addition, portions of this particular canal pass through upland habitats, and overhanging trees occasionally obscure rock rip-rap walls (fig. 13), which were erroneously labeled as natural/vegetated bank substrate. Figure 14 shows a thin strip of degraded land that was natural shoreline, which can be difficult to recognize in the lower-resolution aerial photography from 1978-79.

\section{Discussion}

Rates of shoreline advancement (land gain with canal narrowing) and retreat (erosion with canal widening) were highly variable both within and across nonarmored portions of navigation canals. Our results indicate that the underlying geology of the canal banks and the vegetation type influenced the rate of shoreline change. In general, erosion rates increased along the salinity gradient of marsh vegetation types, with brackish and salt marshes exhibiting the highest erosion rates and fresh marsh the lowest. In terms of geologic regions, portions of canals occurring in the chenier plain generally had the highest erosion rates. This result is contrary to findings of other studies that indicate that land loss is generally highest in the Mississippi deltaic plain region (Britsch and Dunbar, 1993); however, it is likely that erosion rates throughout the study area could also be influenced by differences in levels of vessel traffic, local subsidence rates, and other potentially confounding factors not included in this study.

Canal widening rates reported by other studies were similar to our findings. In a similar study completed in the Leeville Oil and Gas Field, Johnson and Gosselink (1982) reported that minor canals with little vessel traffic widened at a rate of $-0.95 \mathrm{~m} /$ year $(-3.11 \mathrm{ft} /$ year), while more heavily traveled, major canals widened faster, at a rate of $-2.25 \mathrm{~m} /$ year $(-7.38 \mathrm{ft} /$ year). This compares closely with our results, which show a mean canal widening rate of $-2.48 \mathrm{~m} /$ year $(-8.14 \mathrm{ft} /$ year) for the Bayou Lafourche Cutoff, La., the canal in our study area that is nearest to the Leeville Oil and Gas Field. Johnston and others (unpub. data, 2007) reported widening rates for several of the same canals in our study, although the widening rates in that study were calculated over earlier time periods. The canal widening rates recorded by Johnston and others (unpub. data, 2007) for 1980-1992 were 47 percent higher on average than our findings for 1978-2006 (although the dates included in the two studies do not match exactly, this is the closest comparison available to us).

Canal widening rates (table 7) were highest in the Theodore Ship Channel, Ala. (-6.47 m/year -[21.23 ft/year]), and the Baptiste Collette Bayou channel, La. (-6.34 m/year [-20.80 ft/year]). The Theodore Ship Channel is the smallest canal in the study area and is extensively armored (59 percent of the canal), so the high annual widening rate only applies to a relatively small area. The Baptiste Collette Bayou channel is dredged annually and is an important alternate shipping route when the Industrial Canal in New Orleans is closed or when the navigation canal lock is not functioning. Only 29 percent of the east bank and 21 percent of the west bank of Baptiste Collette Bayou channel is armored.

Five canals narrowed during the time period under study (1978-2006), including the Atchafalaya River, La., Freeport Harbor Channel, Tex., Galveston Ship Channel, Tex., Main Pass channel, La., and Pass a Loutre channel, La. The Atchafalaya River and Pass a Loutre channel canals had the highest rates of canal narrowing (shoreline advance), with rates of $2.58(8.46 \mathrm{ft} /$ year $)$ and $1.75 \mathrm{~m} /$ year $(5.74 \mathrm{ft} /$ year $)$, respectively (table 7). The Atchafalaya basin has a lower rate of wetland loss than other basins in Louisiana because it has the highest amount of riverine flow and sediment load (Day and others, 2000). The Pass a Loutre channel, in the bird's foot delta of the Mississippi River, was historically the main channel of the river but is no longer a major navigation canal. The Main Pass channel, which is also in the Mississippi River Delta, is narrowing at a rate of $1.62 \mathrm{~m} /$ year $(5.31 \mathrm{ft} /$ year $)$. There were large mudflats of up to $200-\mathrm{m}$ (656-ft) wide in the canal that were not defined as shoreline in 2006 but that may become dry land in the near future, which would result in even greater shoreline advancement at this canal (fig. 15). Although the Galveston Ship Channel and Freeport Harbor Channel in Texas narrowed during the study time period, both channels are armored along the majority of their lengths ( 75 percent and 92 percent, respectively); therefore, these canals exhibit no movement in canal bank position at all along most of their lengths.

Although we were able to derive useful information about canal widening and narrowing rates, there are some significant limitations to our study. For example, erosion in parts of the Tiger Pass, La. channel is so extensive that there is no longer any shoreline at all in some places. Because erosion cannot be measured where shoreline does not exist, these areas of land loss did not factor into the erosion calculations. This lack of measurability biases the results towards lower mean erosion rates. Another potential source of bias is the removal of transects that intersected banks that were natural in some years and armored in later years. Canal banks with severe rates of erosion were probably more likely to be targeted for construction of armaments, such as rock rip-rap, and thus were not included in the shoreline change calculations. 




Figure 12. Rates of annual shoreline change (in meters per year) associated with the west side of the Bayou Lafourche Cutoff navigation canal, La. Rates of change are based on linear regression (standard error bars are provided). 


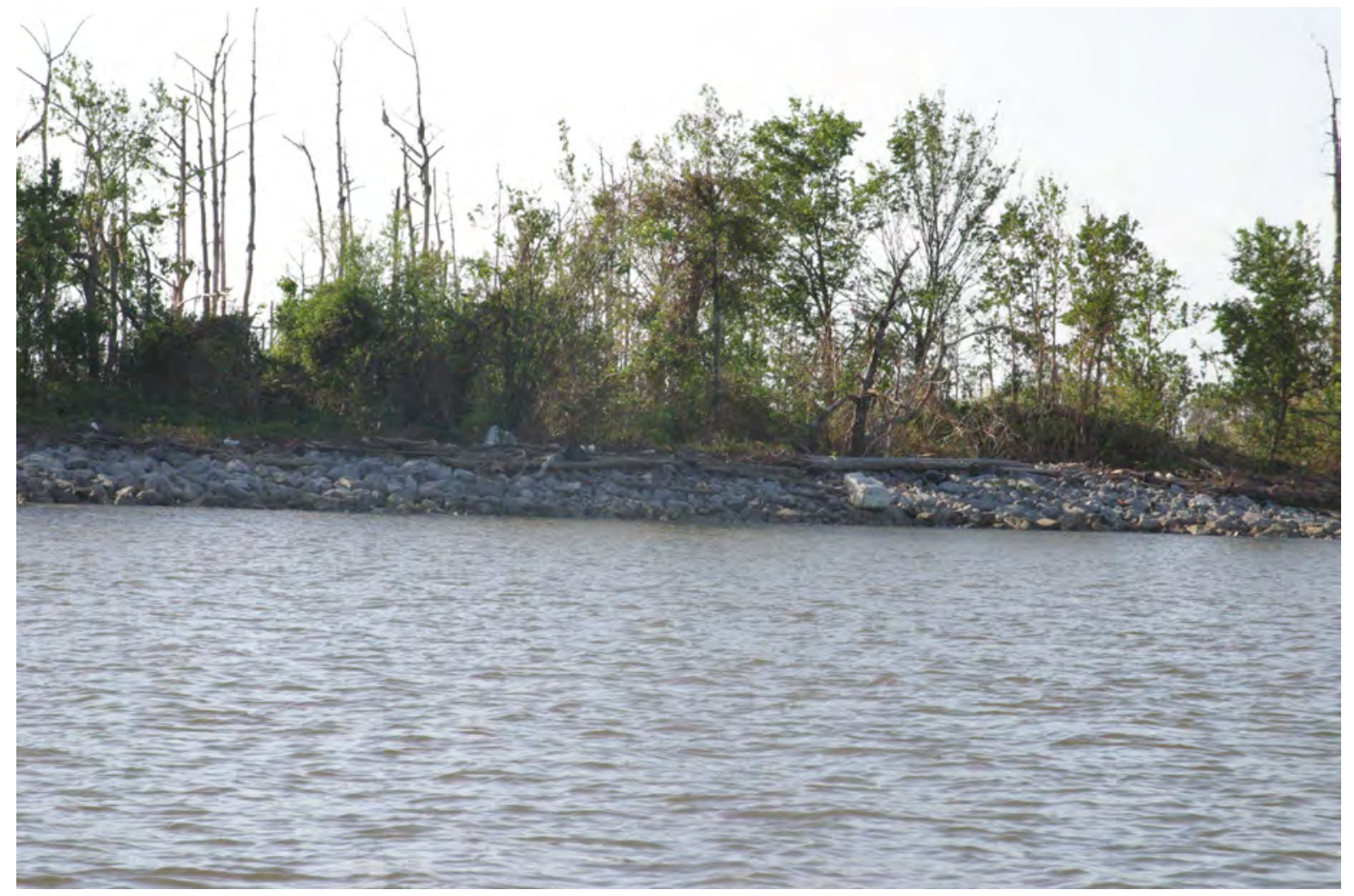

Figure 13. Bank of the Houma Navigation Canal in Louisiana, taken in 2008. This short segment of rock rip-rap is obscured by overhanging trees, making it difficult to identify the canal bank substrate by using 1-m (3.3-ft) resolution aerial photography obtained in 2005.

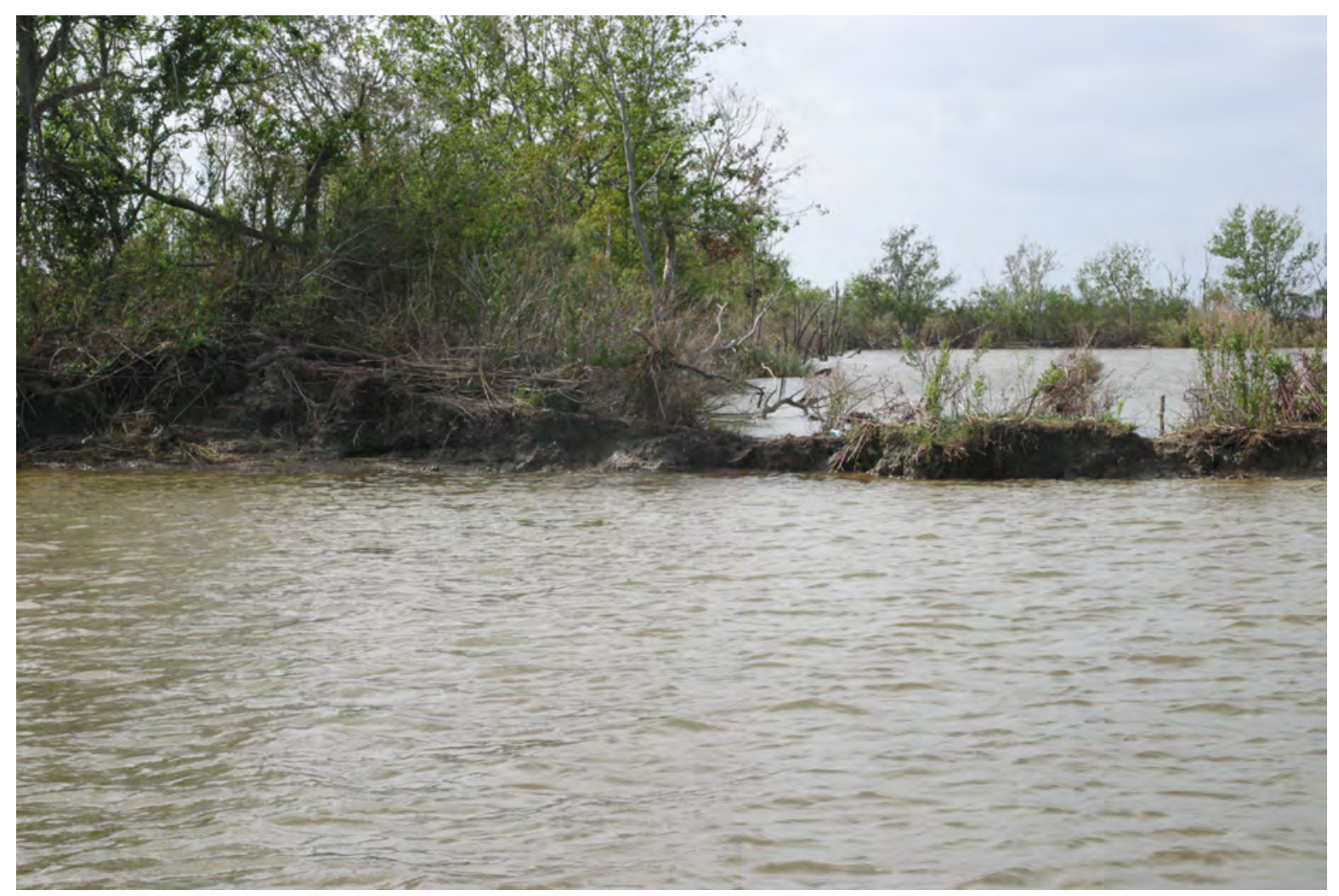

Figure 14. Bank of the Houma Navigation Canal, La., taken in 2008, showing a thin strip of degraded natural shoreline. 




Figure 15. Mudflats in the channel near the mouth of the Main Pass channel, La., are evident in this 2006 aerial photograph. 
Previous studies (Barras and others, 2003; Day and others, 2000) have found that canal erosion rates have slowed in recent years, and results of this study support that conclusion (table 13). Combining the mean EPR for all canals together for each time period, the average canal widening rate slowed to $-0.99 \mathrm{~m} /$ year $(-3.25 \mathrm{ft} /$ year) for the 1996/982005/06 time period compared to $-1.71 \mathrm{~m} /$ year $(-5.61 \mathrm{ft} /$ year) for the earlier 1978/79-1996/98 time period. Another study notes that a reduction in canal widening in recent years is likely a result of restoration activities and construction of rock rip-rap protection along portions of some canals (Johnston and others, unpub. data, 2007). However, although known restoration sites and armored shorelines were eliminated from our analyses, canal widening rates were still lower overall during the 1996/98-2005/06 time period than in the 1978/791996/98 period.

Long-term erosion rates do not imply consistent erosion rates from year to year. A single event, such as a major hurricane, can cause a surge of erosion activity that drives the long-term average erosion rate upwards (Penland and others, 1990). Some of the canal widening rates reported in this study include the impacts of Hurricanes Katrina and Rita in 2005, which likely influenced the long-term erosion rates reported in this study for canals in Louisiana. (Hurricanes Katrina and
Rita made landfall on the Gulf of Mexico coast in August and September of 2005, respectively, while the 2005 aerial photos were acquired from 10/15/2005 to 11/18/2005.) Tides, seasonal variations in river water levels, and upstream rainfall events are also sources of natural variability in delineating shoreline position.

The wave energy generated by vessel traffic is also a potentially important factor contributing to shoreline erosion rates; however, data on the annual vessel traffic collected by the U.S. Army Corps of Engineers lacks sufficient detail to determine vessel traffic levels by canal or by the size of the vessels. Future research could focus on obtaining this vessel traffic information for individual canals in order to more accurately quantify the factors that influence canal bank erosion. This information could help predict future erosion rates or direct limited resources for armament construction towards the most vulnerable sections of navigation canals.

This study does not address the indirect impacts of navigation canals on interior marsh loss; however, the spoil banks and levees associated with the construction and maintenance (for example, dredging) of navigation canals have likely contributed to marsh loss through alteration in the local hydrology (Day and others, 2000). The spoil banks can reduce the sediment and nutrient inputs to the surrounding

Table 13. Difference in rates of shoreline change between two time periods (1978/79-1996/98 and 1996/98-2005/06) in navigation canals in the northern Gulf of Mexico.

[EPR, end point rate ; SE, standard error]

\begin{tabular}{lccccc} 
& Mean EPR & SE & Mean EPR & SE & Change in EPR \\
\cline { 2 - 6 } \multicolumn{1}{c}{ Name } & $\mathbf{1 9 7 8 / 7 9 - 1 9 9 6 / 9 8}$ & & $\mathbf{1 9 9 6 / 9 8 - 2 0 0 5 / 0 6}$ & & 1.78 \\
Atchafalaya River, La. & 2.22 & 0.30 & 4.01 & 0.65 & 3.25 \\
Baptiste Collette Bayou channel, La. & -7.09 & 0.13 & -3.84 & 0.21 & -0.02 \\
Bayou Lafourche Cutoff, La. & -2.48 & 0.13 & -2.49 & 0.15 & -1.47 \\
Calcasieu Ship Channel, La. & -1.94 & 0.12 & -3.41 & 0.13 & -4.20 \\
Freeport Harbor Channel, Tex. & 1.52 & 0.36 & -2.67 & 0.40 & -0.34 \\
Freshwater Bayou Channel, La. & -2.62 & 0.07 & -2.96 & 0.11 & -0.30 \\
Galveston Ship Channel, Tex. & 0.95 & 0.45 & 0.65 & 0.28 & 1.36 \\
Houma Navigation Canal, La. & -3.24 & 0.08 & -1.89 & 0.07 & -0.64 \\
Main Pass channel, La. & 1.77 & 0.08 & 1.12 & 0.13 & 1.36 \\
Mississippi River Mouth Pass, La. & -3.04 & 0.44 & -1.67 & 0.23 & 0.66 \\
Pascagoula Channel, Miss. (large channel) & -0.97 & 0.10 & -0.31 & 0.08 & -1.32 \\
Pascagoula Channel, Miss. (small channel) & -0.46 & 0.14 & -1.78 & 0.70 & 0.47 \\
Pass a Loutre channel, La. & 1.64 & 0.09 & 2.11 & 0.46 & -0.56 \\
South Pass channel, La. & 0.12 & 0.07 & -0.44 & 0.14 &. \\
Southwest Pass channel, La. &. &. &. &. & 6.36 \\
Theodore Ship Channel, Ala. & -8.20 & 0.77 & -1.84 & 0.32 & 5.10 \\
Tiger Pass channel, La. & -5.48 & 0.27 & -0.38 & 0.43 & \\
\hline
\end{tabular}


landscape associated with marsh flooding. In addition, the navigation canal itself provides a pathway for saltwater intrusion (Day and others, 2000; Baumann and Turner, 1990), which is associated with land loss.

The spatially explicit data on canal bank substrate and erosion from this study could be used in future studies of landscape changes in the BOEMRE-designated western and central planning areas of the Gulf of Mexico coast. Substrate type (for example, rock rip-rap walls compared to vegetated banks) and variations in erosion rates may be contributing factors in the broader questions regarding why wetland loss rates vary across the gulf coast, particularly in coastal Louisiana.

\section{Conclusions}

If the goal in managing navigation canals is to reduce erosion at the land-water interface, then constructing armaments such as rock walls and concrete bulkheads may be an effective strategy. Approximately 70 percent of the navigation canal banks in the study area were nonarmored in 2005 or 2006 . The highest erosion rates occurred in navigation canal segments located in salt marshes, in the chenier plain geologic region, and in areas with a higher percent organic content in soils.

The results of this study could be used to help direct the construction of shoreline armaments to areas with the highest erosion rates; however, additional investigation is needed to determine how the construction of canal bank armaments could affect interior marshes. For example, the addition of structures such as rock walls could affect the movement of water, sediments, and nutrients between canals and nearby marshes. In addition, obtaining vessel traffic data to include in the analysis would further help explain why some sections of canals erode faster than others and could be used to help refine estimates of future erosion rates for individual canals. This information could help predict the potential increase in erosion rates associated with any increase in the number of vessels creating wakes.

\section{References Cited}

Barras, J., Beville, S., Britsch, D., Hartley, S., Hawes, S., Johnston, J., Kemp, P., Kinler, Q., Martucci, A., Porthouse, J., Reed, D., Roy, K., Sapkota, S., and Suhayda, J., 2003, Historical and projected coastal Louisiana land changes, 1978-2050: U.S. Geological Survey Open-File Report 03-334, $39 \mathrm{p}$.
Baumann, R.H., and Turner, R.E., 1990, Direct Impacts of Outer Continental Shelf Activities on Wetland Loss in the Central Gulf of Mexico: Environmental Geology v. 15 no. 3, p. 189-198.

Boak, E.H., and Turner, I.L., 2005, Shoreline definition and detection-A review: Journal of Coastal Research, v. 21, p. 688-703.

Britsch, L.D., and Dunbar, J.B., 1993, Land-loss ratesLouisiana coastal plain: Journal of Coastal Research v. 9, p. 324-338.

Day, J.W., Shaffer, G.P., Britsch, L.D., Reed, D.J., Hawes, S.R., and Cahoon, D.R., 2000, Pattern and process of land loss in the Mississippi Delta-A spatial and temporal analysis of wetland habitat change: Estuaries, v. 23, no. 4, p. 425-438.

Dolan, R., Fenster, M.S., and Holme, S.J., 1991, Temporal analysis of shoreline recession and accretion: Journal of Coastal Research, v. 7, p. 723-744.

Gibeaut, J.C., T. Hepner, R. Waldinger, J. Andrews, R. Gutierrez, T.A. Tremblay, T.A., and Smyth, R., 2001, Changes in Gulf Shoreline position, Mustang, and North Padre Islands, Texas. Austin, Texas, The University of Texas at Austin, Bureau of Economic Geology, 28 p.

Honeycutt, M.G., Crowell, M., and Douglas, B.C., 2001, Shoreline-position forecasting - Impact of storms, ratecalculation methodologies, and temporal scales: Journal of Coastal Research, v. 17, p. 721-730.

Johnson, W.B., and Gosselink, J.G., 1982, Wetland loss directly associated with canal dredging in the Louisiana Coastal Zone, in Boesch, D.F., ed., Proceedings of the Conference on Coastal Erosion and Wetland Modification in Louisiana-Causes, Consequences, and Options, Baton Rouge, Louisiana, October 5-7, 1981: Washington, D.C., U.S. Fish and Wildlife Service FWS/OBS-82/59, p. 60-72.

Linscombe, Greg, and Chabreck, R.H., 1997, 1997 Louisiana coastal marsh-Vegetative type map [spatial dataset]: U.S. Geological Survey National Wetlands Research Center Spatial Analysis Branch digital library product USGSNWRC 1997-02-0132, accessed August 23, 2009, at http:// sabdata.cr.usgs.gov/sabnet_pub/pub_sab_app.as.

Morton, R.A., Miller, T.L., and Moore, L.J., 2004, The national assessment of shoreline change-Part 1 historical shoreline changes and associated coastal land loss along the U.S. Gulf of Mexico: U.S. Geological Survey Open-File Report 2005-1043, 35 p. 
Morton, R.A., Bernier, J.C., Barras, J.A., and Ferina, N.F., 2005, Rapid subsidence and historical wetland loss in the Mississippi Delta Plain-Likely causes and future implications: U.S. Geological Survey Open-File Report 2005-1216, $116 \mathrm{p}$.

Morton, R.A., Miller, T.L., and Moore, L.J., 2005, Historical Shoreline Changes Along the US Gulf of Mexico: A Summary of Recent Shoreline Comparisons and Analyses: Journal of Coastal Research v. 21, p. 704-709.

Natural Resources Conservation Service, n.d., Soil Survey Geographic (SSURGO) Database for Texas, Louisiana, Mississippi, and Alabama: United States Department of Agriculture, Natural Resources Conversation Service, accessed online July 15, 2009, at http://soildatamart.nrcs. usda.gov.

Omernik, J.M., 1987, Ecoregions of the conterminous United States: Annals of the Association of American Geographers, v. 77 , p. $118-125$.

Penland, S., Roberts, H.H., Williams, S.J., Sallenger, Jr., A.H., Cahoon, D.R., Davis, D.W., and Groat, C.G., 1990, Coastal land loss in Louisiana: Gulf Coast Association of Geological Societies Transactions, v. 40, p. 685-699.

Price, F., 2006, Quantification, analysis, and management of Ubtraciastak /waterway channel margin erosion in the Guana Tolomato Matanzas National Estuarine Research Reserve, Florida: National Estuarine Research Reserve Technical Report Series 2006:1, 61 p.

Ramsey, K.E., and Penland, S., 1989, Sea-level rise and subsidence in Louisiana and the Gulf of Mexico: Gulf Coast Association of Geological Societies Transactions, v. 39, p. 491-500.
Sasser, C.E., Visser, J.M., Mouton, Edmond, Linscombe, Jeb, and Hartley, S.B., 2008, Vegetation types in coastal Louisiana in 2007: U.S. Geological Survey Open-File Report 2008-1224, 1 sheet, scale 1:550,000.

SAS Institute, 2004, SAS/STAT 9.1 User's Guide: SAS Institute, Inc., Cary, North Carolina, USA, 5136 p.

Stockdon, H.F., Sallenger Jr., A.H., List, J.H., and Holman, R.A., 2002, Estimation of shoreline position and change using airborne topographic lidar data: Journal of Coastal Research, v. 18, p. 502-513.

Tabberer, D.T., Hagg, W., Coquat, M., and Cordes, C.L., 1985, Pipeline impacts on wetlands-Final environmental assessment: Metairie, La., U.S. Department of the Interior, Minerals Management Service, $41 \mathrm{p}$.

Thieler, E.R., Himmelstoss, E.A., Zichichi, J.L., and Miller, T.L., 2005, Digital Shoreline Analysis System (DSAS) version 3.0; An ArcGIS extension for calculating shoreline change: U.S. Geological Survey Open-File Report 20051304,33 p.

United States Army Corps of Engineers (USACE), 2004, Louisiana Coastal Area, Louisiana Ecosystem Restoration Study, Volume 1-Main Report, accessed online July 8, 2009, at http://www.lca.gov/final_report.aspx.

Zuzek, P.J., R.B. Nairn, and Thieme, S.J., 2003, Spatial and temporal considerations for calculating shoreline change rates in the Great Lakes Basin: Journal of Coastal Research, v. 38 , p. $125-146$. 



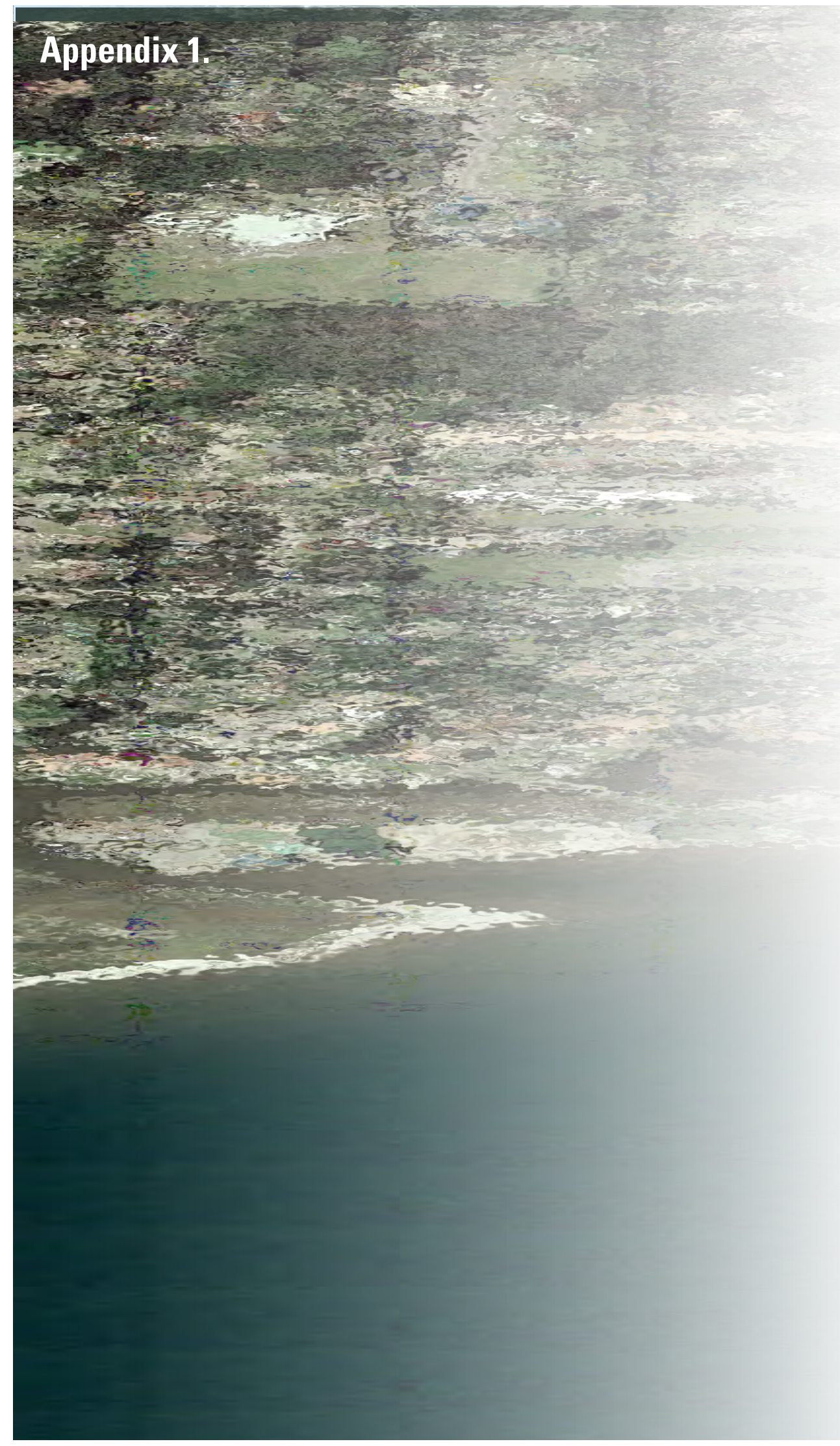




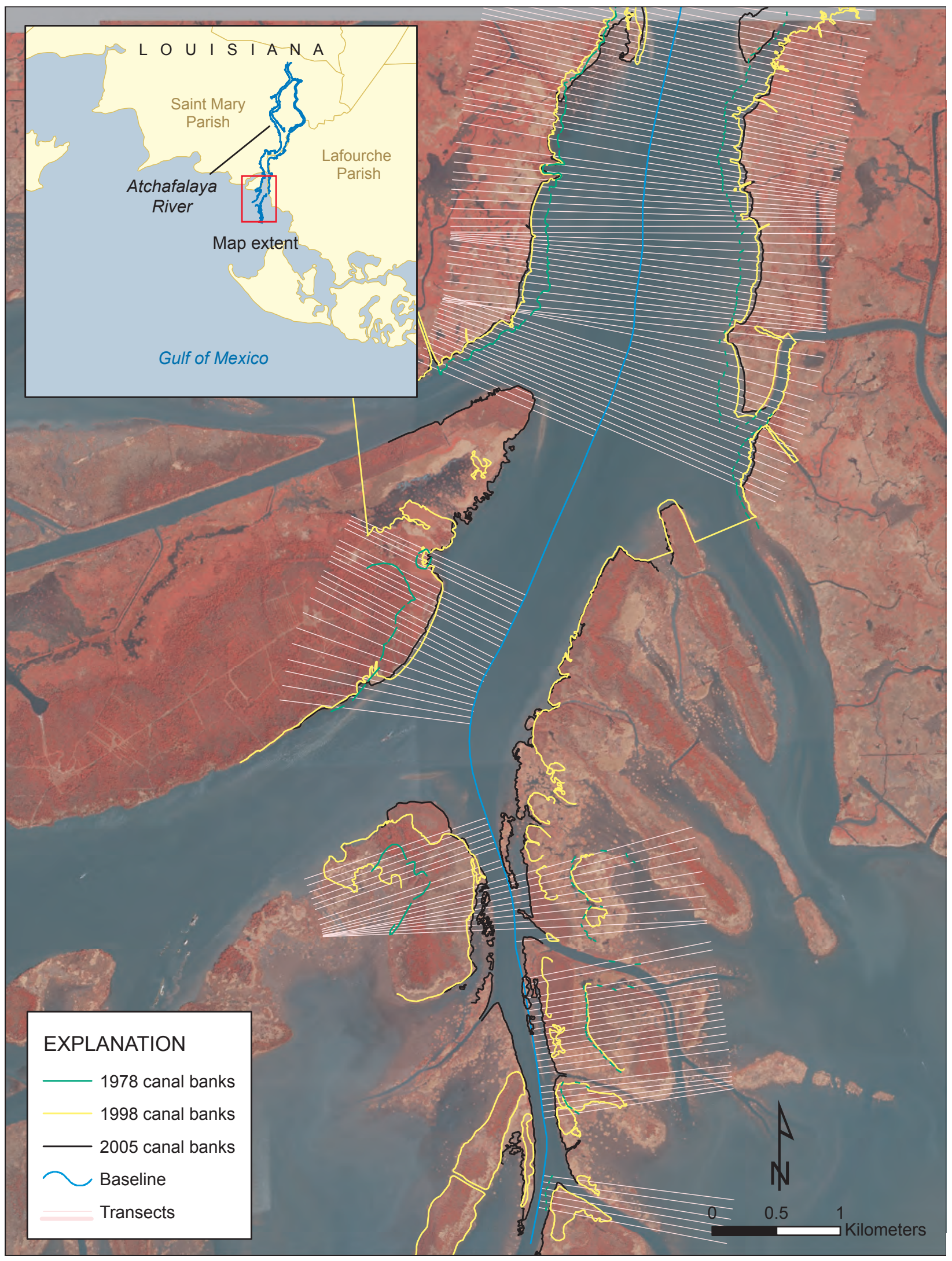

Figure 1-1. Atchafalaya River, La., navigation canal (map 1 of 4), showing canal bank positions digitized for three different time periods. Transects were generated at 50-m intervals to measure erosion rates from 1978-2005 within navigation canals in the Gulf of Mexico. The background imagery consists of 2005 aerial photographs. 




Figure 1-2. Atchafalaya River, La., navigation canal (map 2 of 4), showing canal bank positions digitized for three different time periods. Transects were generated at 50-m intervals to measure erosion rates from 1978-2005 within navigation canals in the Gulf of Mexico. The background imagery consists of 2005 aerial photographs. 




Figure 1-3. Atchafalaya River, La., navigation canal (map 3 of 4), showing canal bank positions digitized for three different time periods. Transects were generated at 50-m intervals to measure erosion rates from 1978-2005 within navigation canals in the Gulf of Mexico. The background imagery consists of 2005 aerial photographs. 




Figure 1-4. Atchafalaya River, La., navigation canal (map 4 of 4), showing canal bank positions digitized for three different time periods. Transects were generated at 50-m intervals to measure erosion rates from 1978-2005 within navigation canals in the Gulf of Mexico. The background imagery consists of 2005 aerial photographs. 


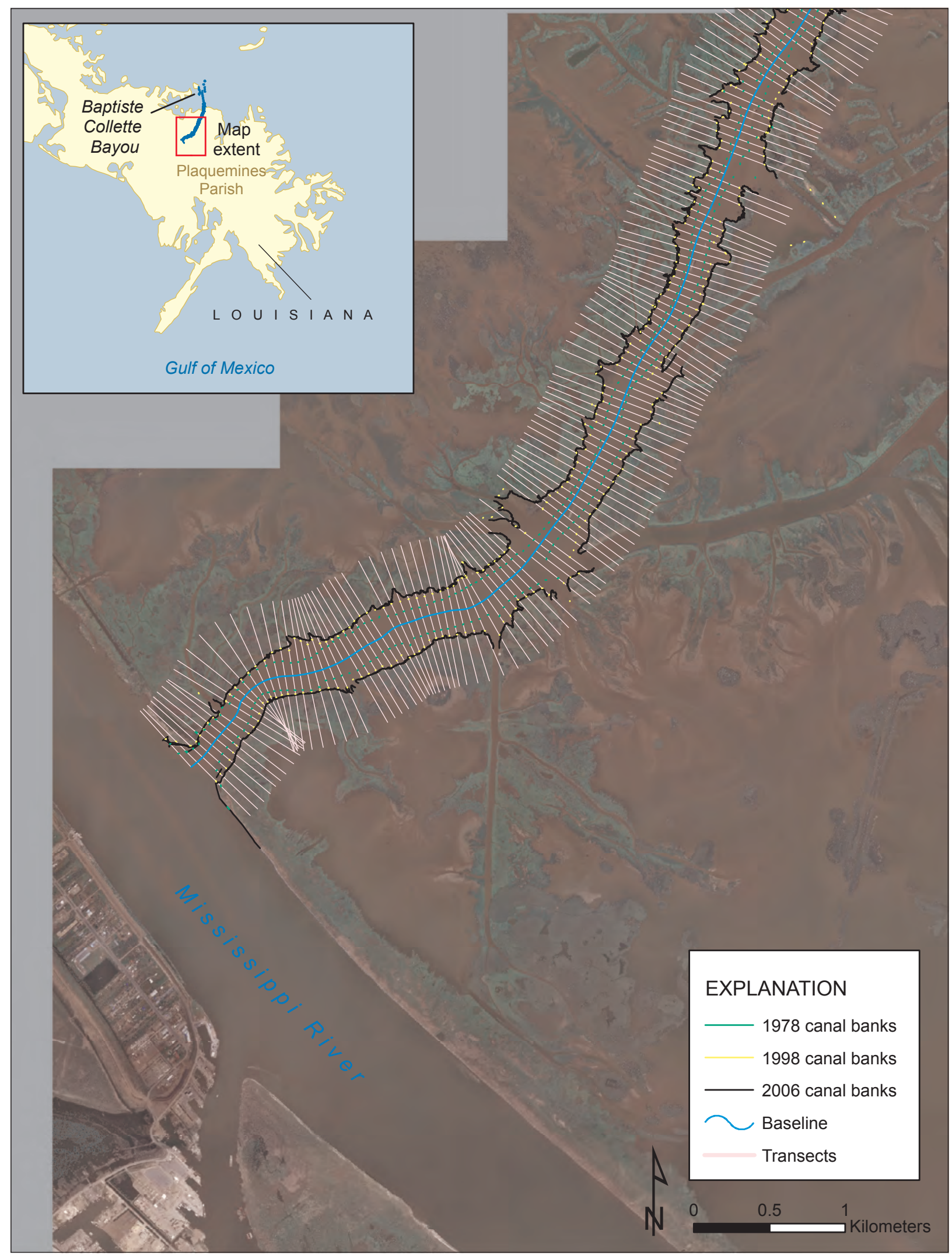

Figure 1-5. Baptiste Collette Bayou channel, La. (map 1 of 2), showing canal bank positions digitized for three different time periods. Transects were generated at 50-m intervals to measure erosion rates from 1978-2006 within navigation canals in the Gulf of Mexico. The background imagery consists of 2006 aerial photographs. 


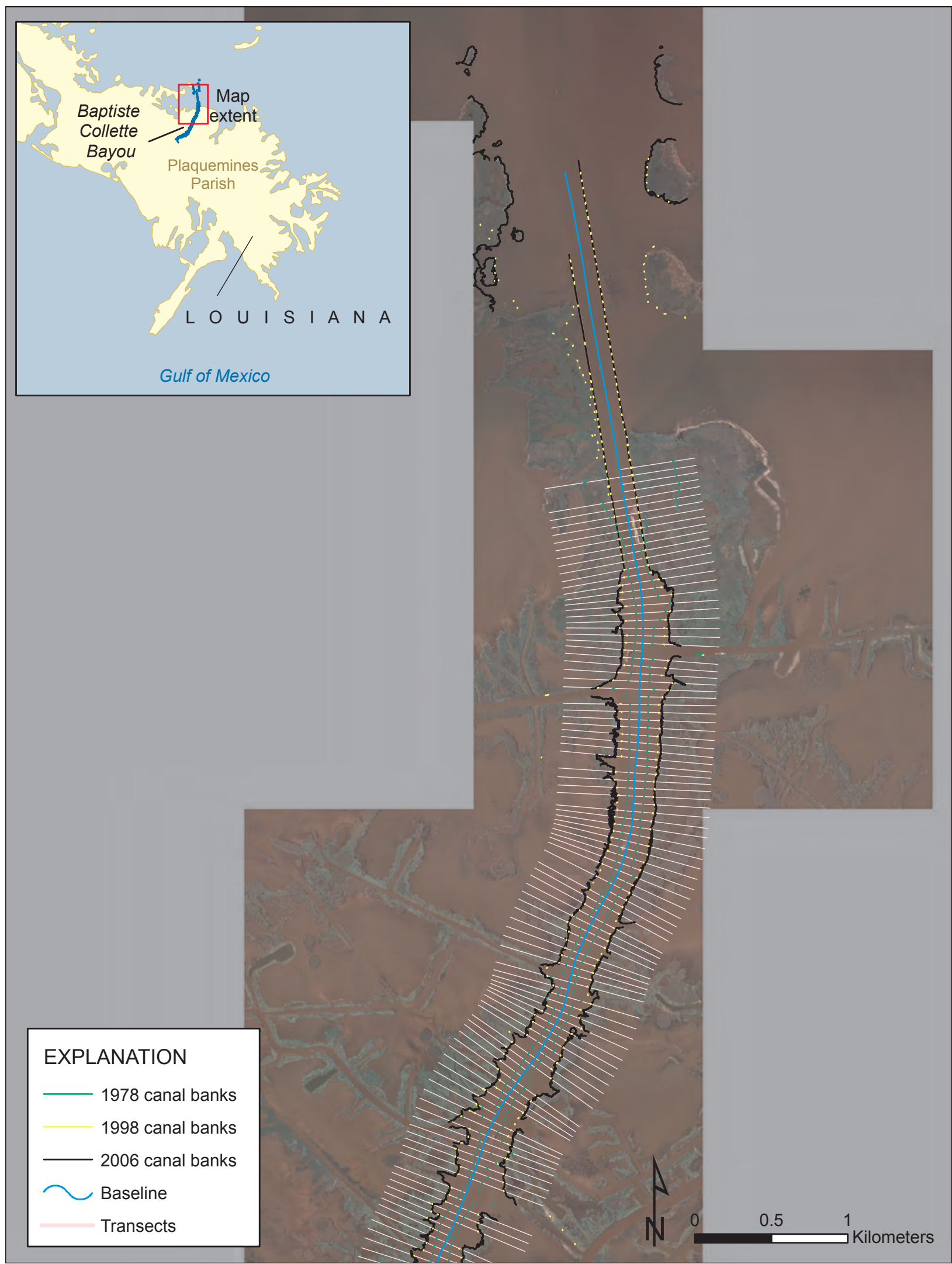

Figure 1-6. Baptiste Collette Bayou, La. navigation canal (map 2 of 2), showing canal bank positions digitized for three different time periods. Transects were generated at 50-me intervals to measure erosion rates from 1978-2006 within navigation canals in the Gulf of Mexico. The background imagery consists of 2006 aerial photographs. 




Figure 1-7. Bayou Lafourche Cutoff, La. (map 1 of 1), showing canal bank positions digitized for three different time periods. Transects were generated at 50-m intervals to measure erosion rates from 1978-2006 within navigation canals in the Gulf of Mexico. The background imagery consists of 2006 aerial photographs. 


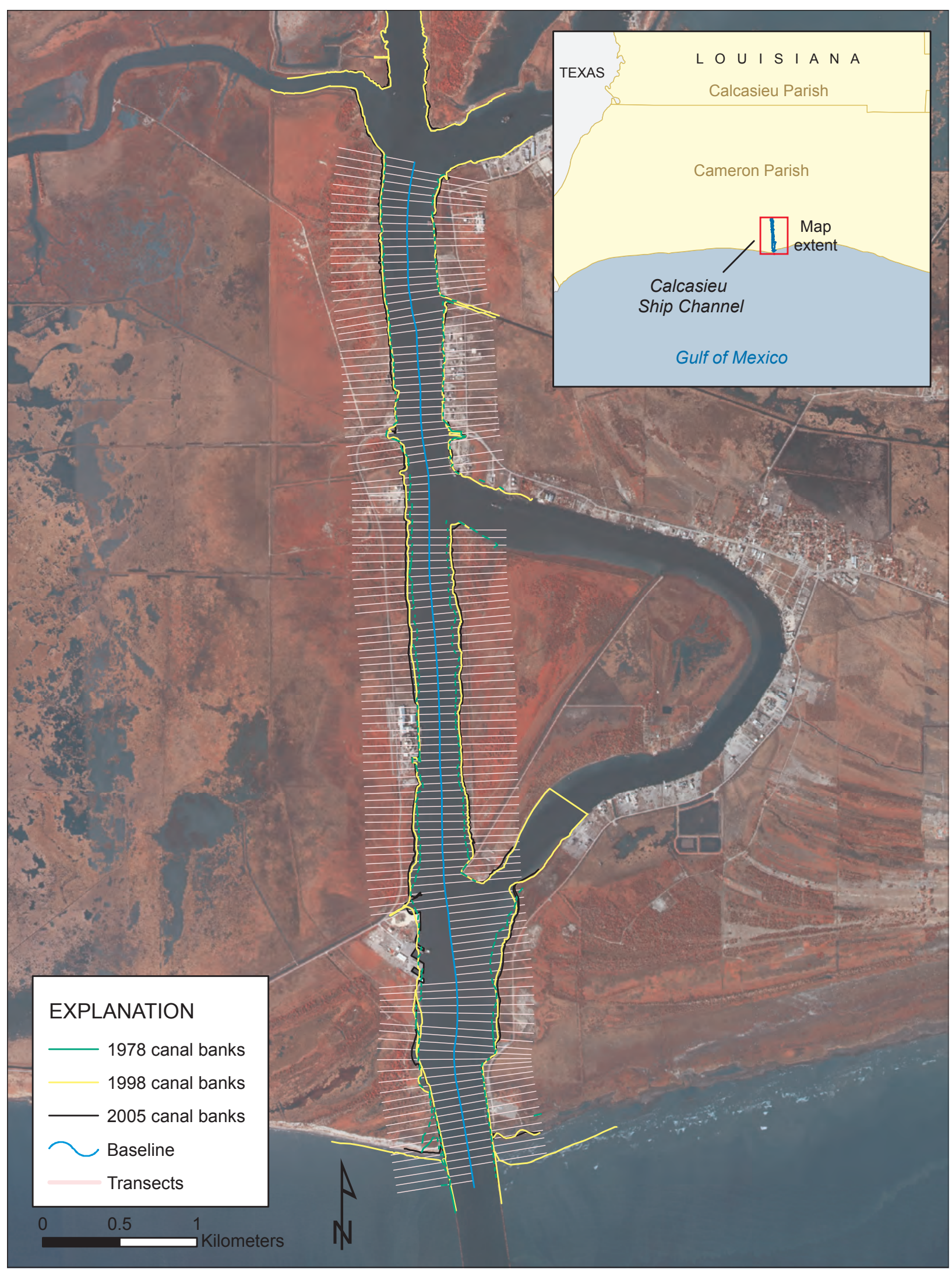

Figure 1-8. Calcasieu Ship Channel, La. (map 1 of 1), showing canal bank positions digitized for three different time periods. Transects were generated at 50-m intervals to measure erosion rates from 1978-2005 within navigation canals in the Gulf of Mexico. The background imagery consists of 2005 aerial photographs. 


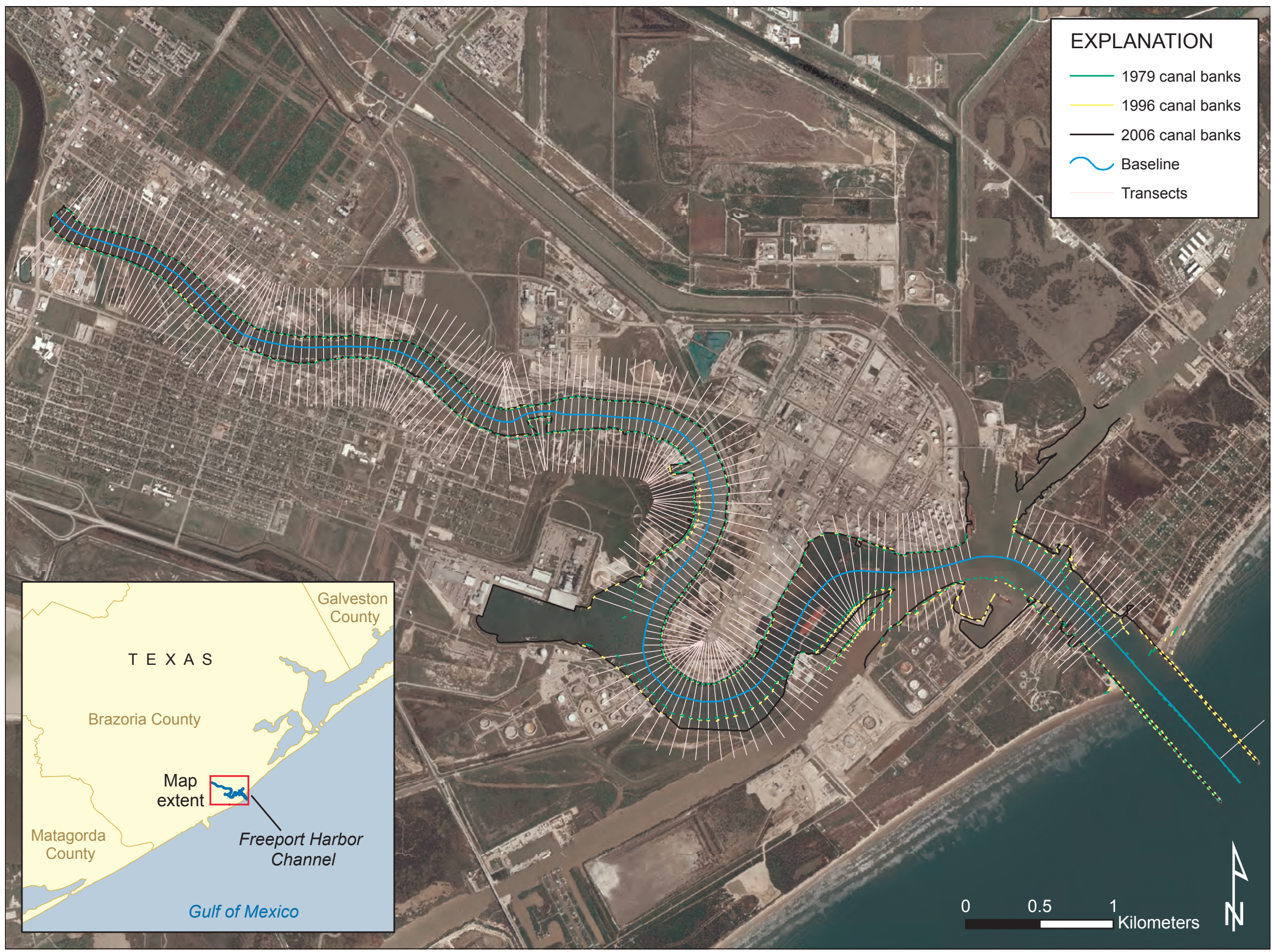

Figure 1-9. Freeport Harbor Channel, Tex. (map 1 of 1), showing canal bank positions digitized for three different time periods. Transects were generated at 50-m intervals to measure erosion rates from 1979-2006 within navigation canals in the Gulf of Mexico. The background imagery consists of 2006 aerial photographs. 




Figure 1-10. Freshwater Bayou Channel, La. (map 1 of 4), showing canal bank positions digitized for three different time periods. Transects were generated at 50-m intervals to measure erosion rates from 1978-2005 within navigation canals in the Gulf of Mexico. The background imagery consists of 2005 aerial photographs. 




Figure 1-11. Freshwater Bayou Channel, La. (map 2 of 4), showing canal bank positions digitized for three different time periods. Transects were generated at 50-m intervals to measure erosion rates from 1978-2005 within navigation canals in the Gulf of Mexico. The background imagery consists of 2005 aerial photographs. 


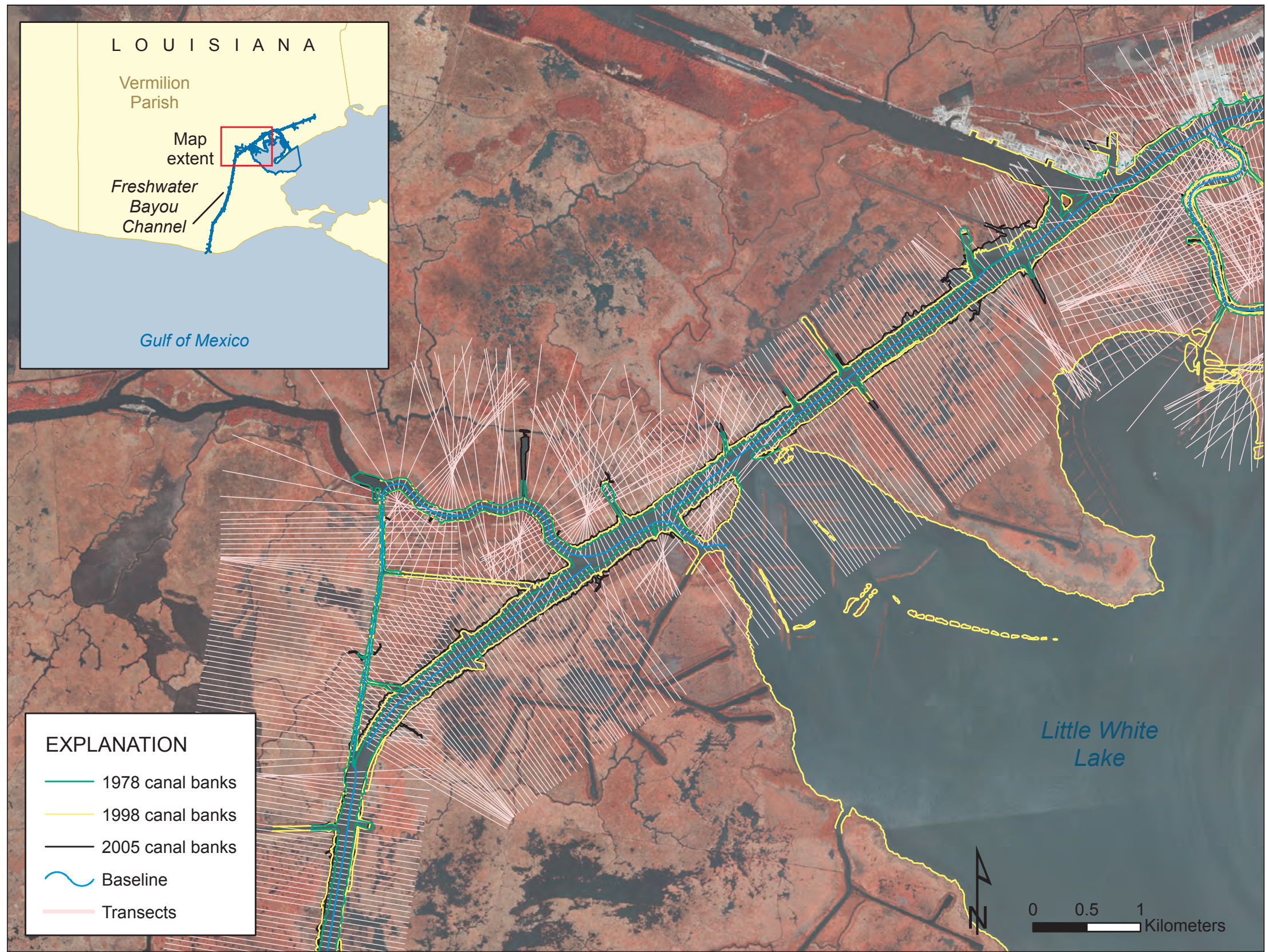

Figure 1-12. Freshwater Bayou Channel, La. (map 3 of 4), showing canal bank positions digitized for three different time periods. Transects were generated at $50-\mathrm{m}$ intervals to measure erosion rates from 1978-2005 within navigation canals in the Gulf of Mexico. The background imagery consists of 2005 aerial photographs. 


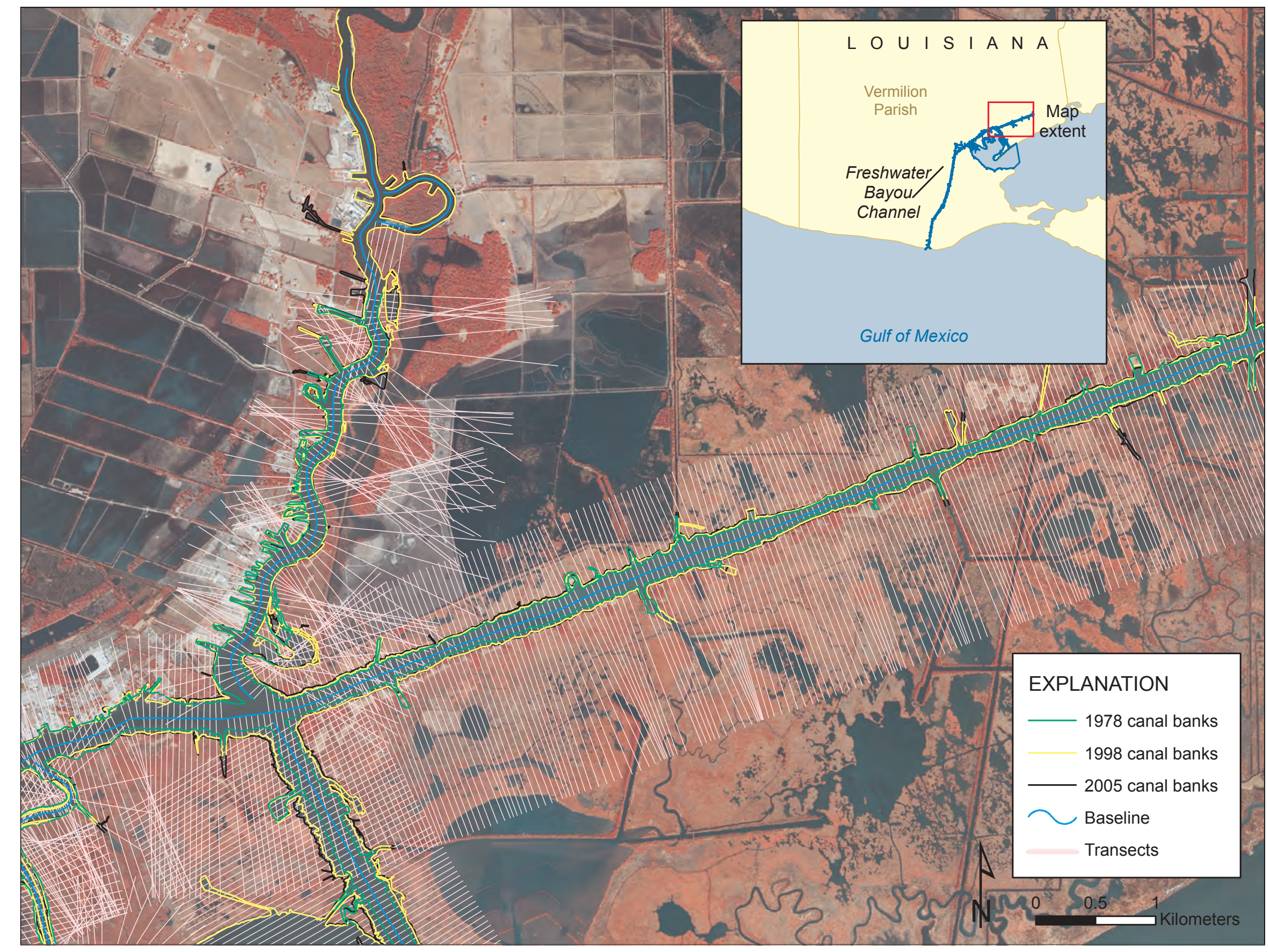

Figure 1-13. Freshwater Bayou Channel, La. (map 4 of 4), showing canal bank positions digitized for three different time periods. Transects were generated at 50-m intervals to measure erosion rates from 1978-2005 within navigation canals in the Gulf of Mexico. The background imagery consists of 2005 aerial photographs. 


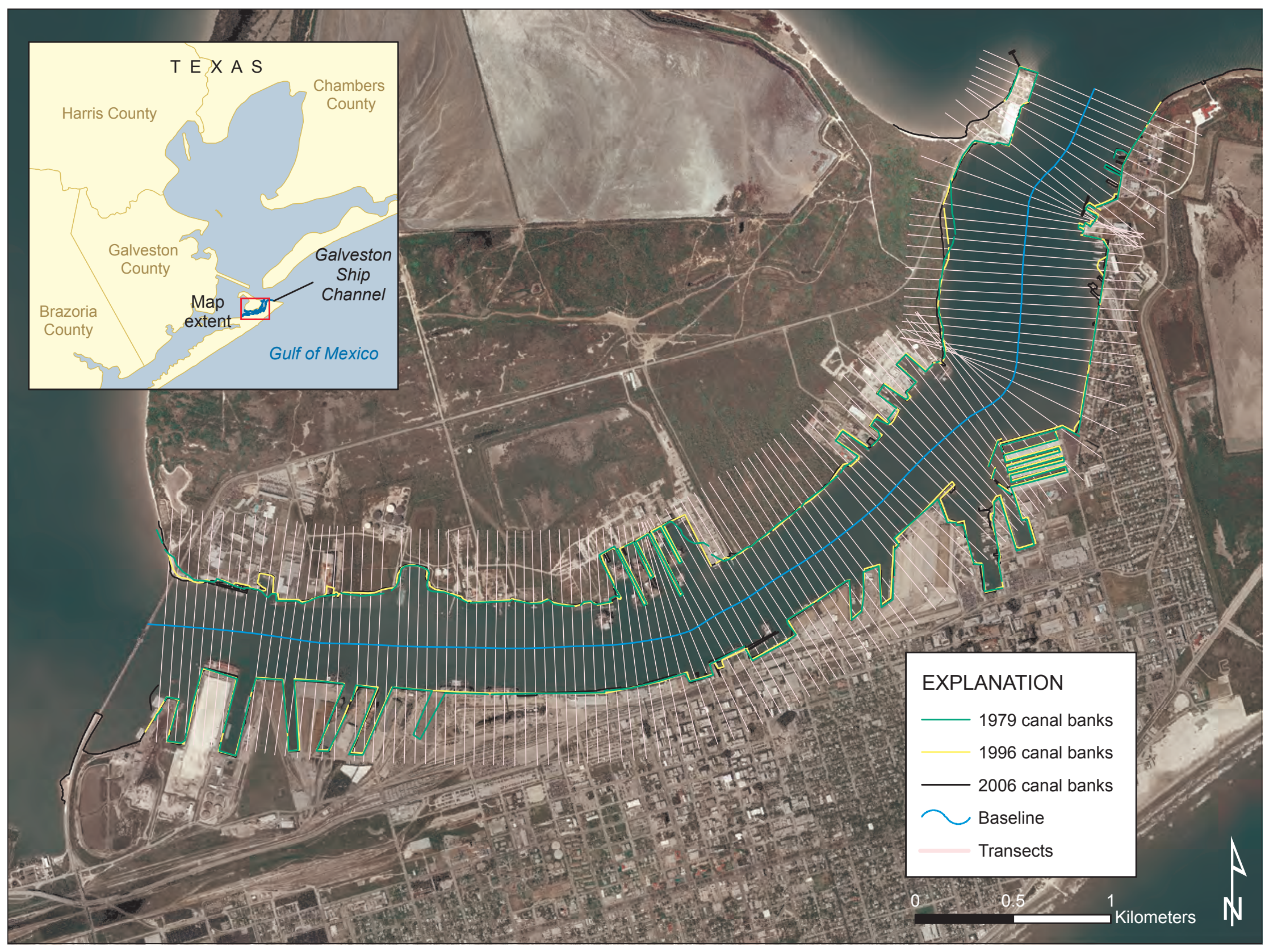

Figure 1-14. Galveston Ship Channel, Tex. (map 1 of 1), showing canal bank positions digitized for three different time periods. Transects were generated at 50-m intervals to measure erosion rates from 1979-2006 within navigation canals in the Gulf of Mexico. The background imagery consists of 2006 aerial photographs. 




Figure 1-15. Houma Navigation Canal, La. (map 1 of 4), showing canal bank positions digitized for three different time periods. Transects were generated at 50-m intervals to measure erosion rates from 1978-2005 within navigation canals in the Gulf of Mexico. The background imagery consists of 2005 aerial photographs. 


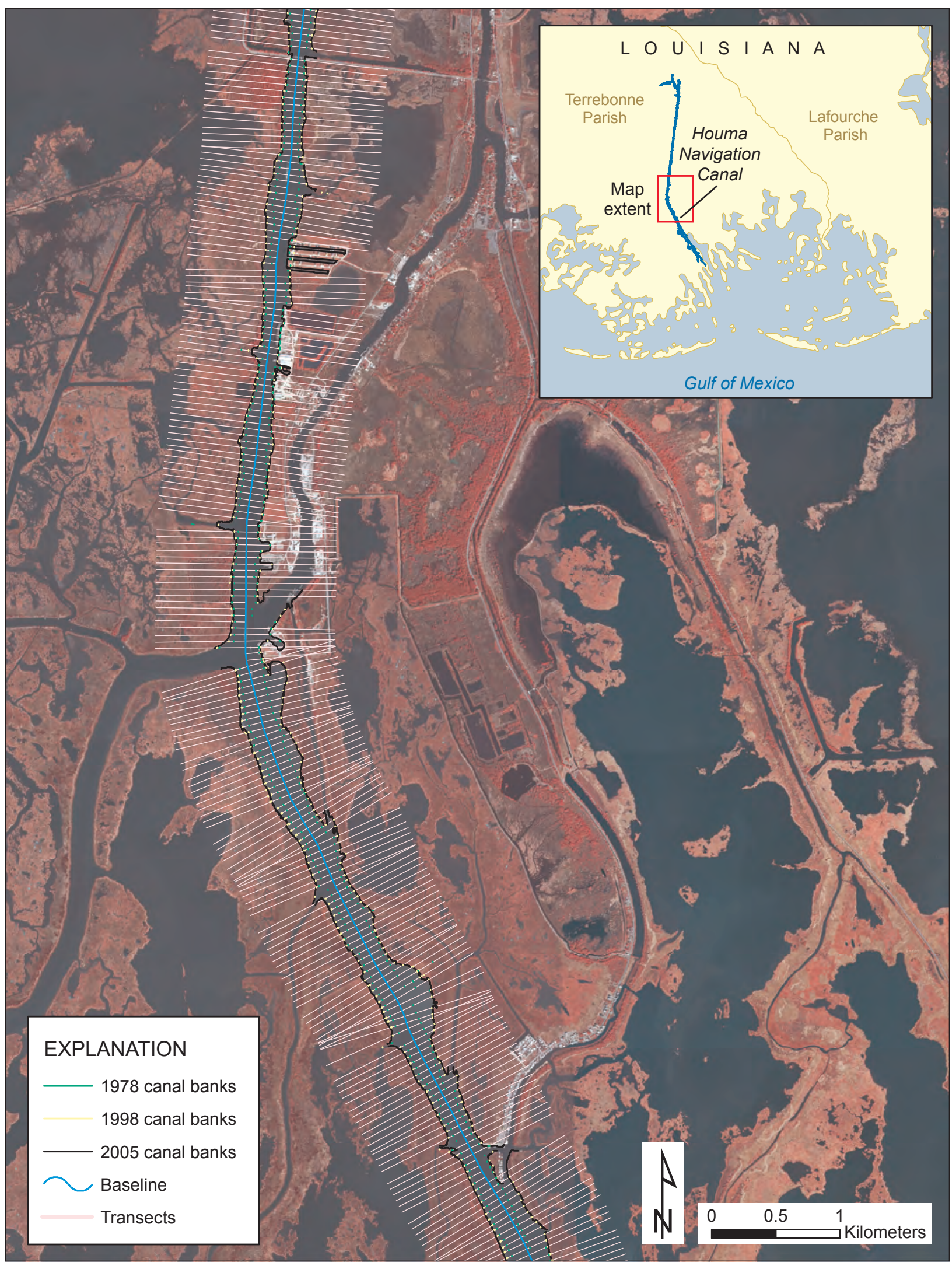

Figure 1-16. Houma Navigation Canal, La. (map 2 of 4), showing canal bank positions digitized for three different time periods. Transects were generated at 50-m intervals to measure erosion rates from 1978-2005 within navigation canals in the Gulf of Mexico. The background imagery consists of 2005 aerial photographs. 


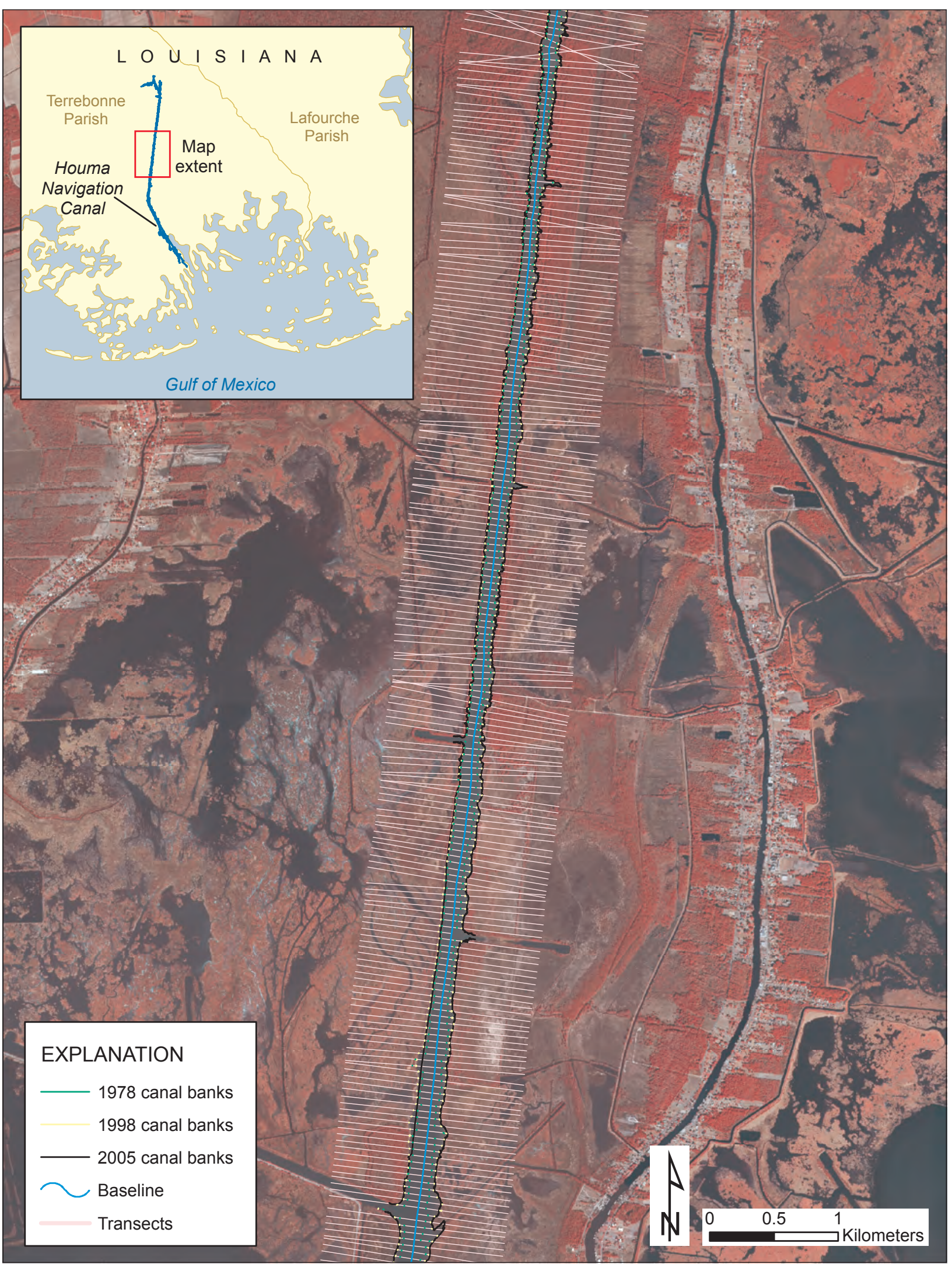

Figure 1-17. Houma Navigation Canal, La. (map 3 of 4), showing canal bank positions digitized for three different time periods. Transects were generated at 50-m intervals to measure erosion rates from 1978-2005 within navigation canals in the Gulf of Mexico. The background imagery consists of 2005 aerial photographs. 




Figure 1-18. Houma Navigation Canal, La. (map 4 of 4), showing canal bank positions digitized for three different time periods. Transects were generated at 50-m intervals to measure erosion rates from 1978-2005 within navigation canals in the Gulf of Mexico. The background imagery consists of 2005 aerial photographs. 


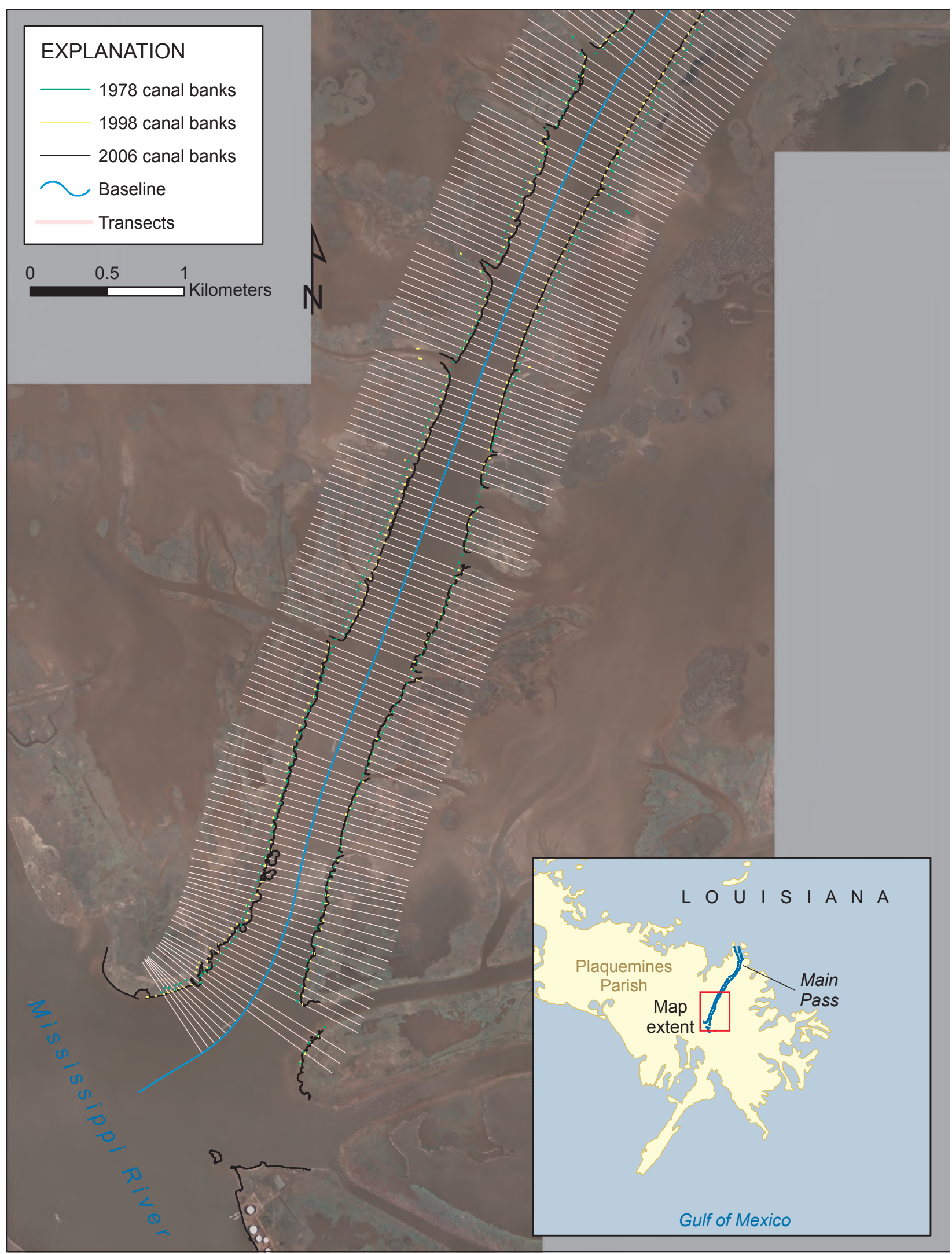

Figure 1-19. Main Pass channel, La. (map 1 of 3), showing canal bank positions digitized for three different time periods. Transects were generated at 50-m intervals to measure erosion rates from 1978-2006 within navigation canals in the Gulf of Mexico. The background imagery consists of 2006 aerial photographs. 


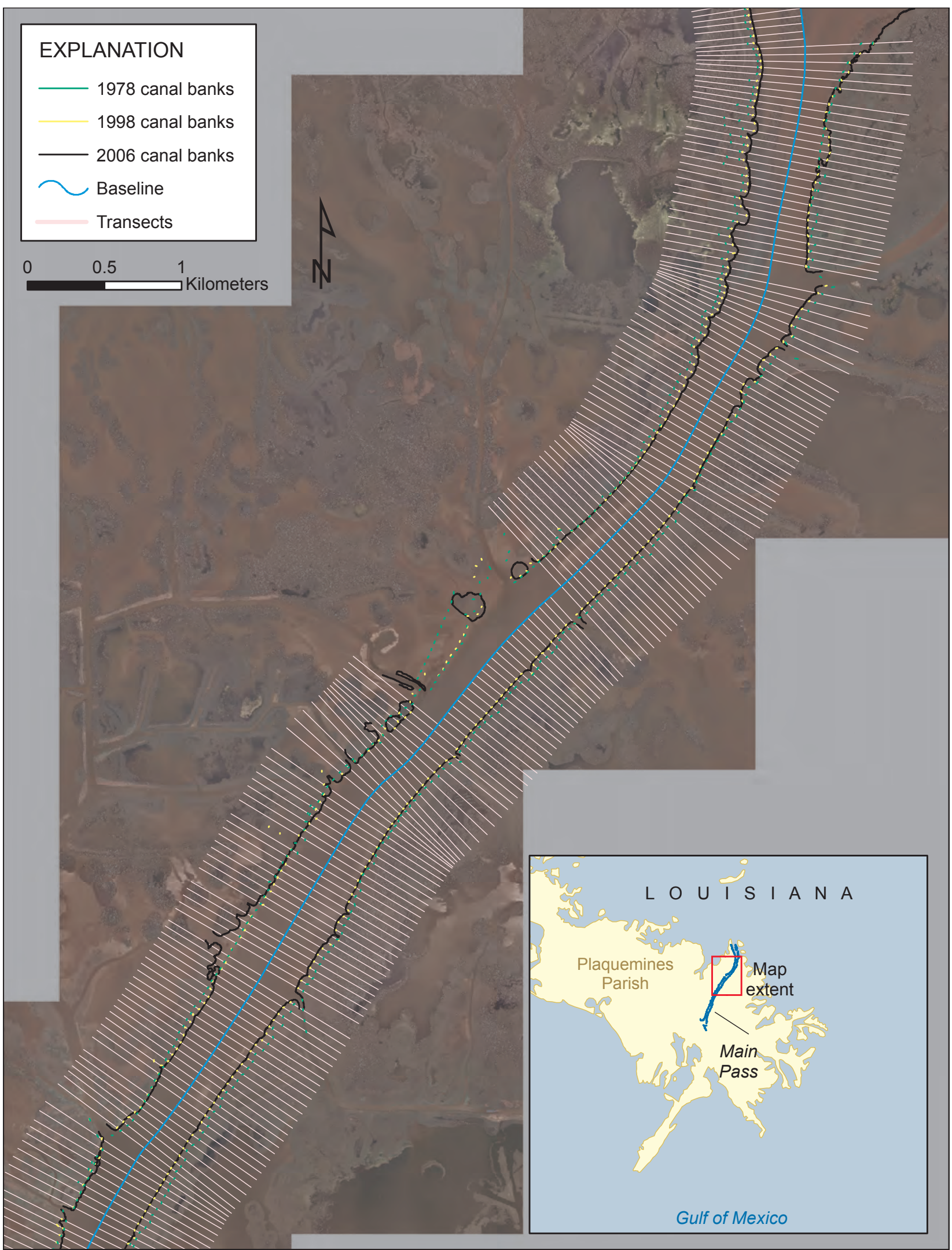

Figure 1-20. Main Pass channel, La. (map 2 of 3), showing canal bank positions digitized for three different time periods. Transects were generated at 50-m intervals to measure erosion rates from 1978-2006 within navigation canals in the Gulf of Mexico. The background imagery consists of 2006 aerial photographs. 




Figure 1-21. Main Pass channel, La. (map 3 of 3), showing canal bank positions digitized for three different time periods. Transects were generated at 50-m intervals to measure erosion rates from 1978-2006 within navigation canals in the Gulf of Mexico. The background imagery consists of 2006 aerial photographs. 


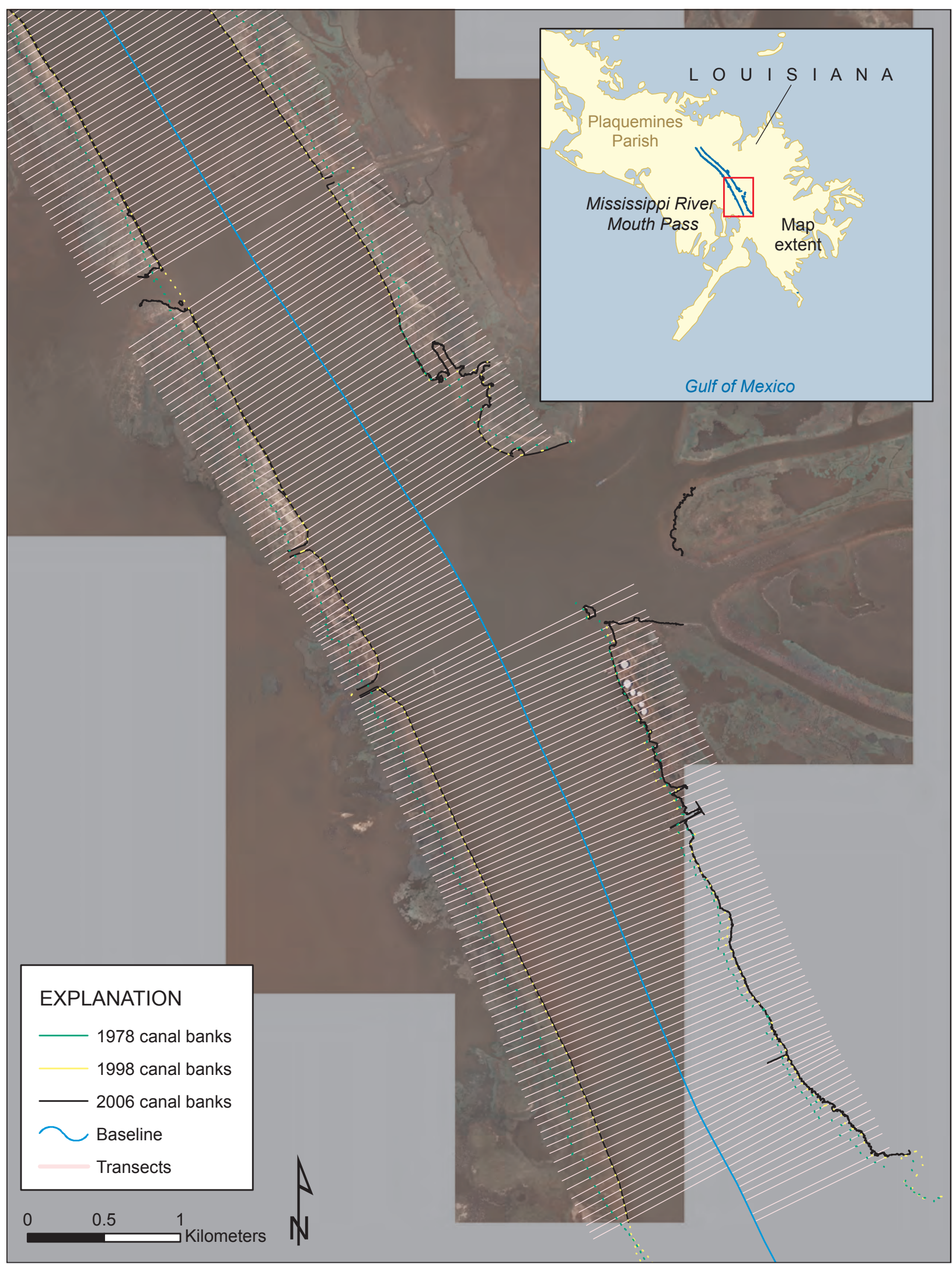

Figure 1-22. Mississippi River Mouth Pass, La. (Map 1 of 2; Mississippi River from Venice, La., to the Head of Passes), showing canal bank positions digitized for three different time periods. Transects were generated at 50-m intervals to measure erosion rates from 1978-2006 within navigation canals in the Gulf of Mexico. The background imagery consists of 2006 aerial photographs. 




Figure 1-23. Mississippi River Mouth Pass, La. (Map 1 of 2; Mississippi River from Venice, La., to the Head of Passes), showing canal bank positions digitized for three different time periods. Transects were generated at 50-m intervals to measure erosion rates from 1978-2006 within navigation canals in the Gulf of Mexico. The background imagery consists of 2006 aerial photographs. 




Figure 1-24. Pascagoula Channel, Miss. (map 1 of 2), showing canal bank positions digitized for three different time periods. Transects were generated at 50-m intervals to measure erosion rates from 1979-2006 within navigation canals in the Gulf of Mexico. The background imagery consists of 2006 aerial photographs. 




Figure 1-25. Pascagoula Channel, Miss. (map 2 of 2), showing canal bank positions digitized for three different time periods. Transects were generated at 50-m intervals to measure erosion rates from 1979-2006 within navigation canals in the Gulf of Mexico. The background imagery consists of 2006 aerial photographs. 


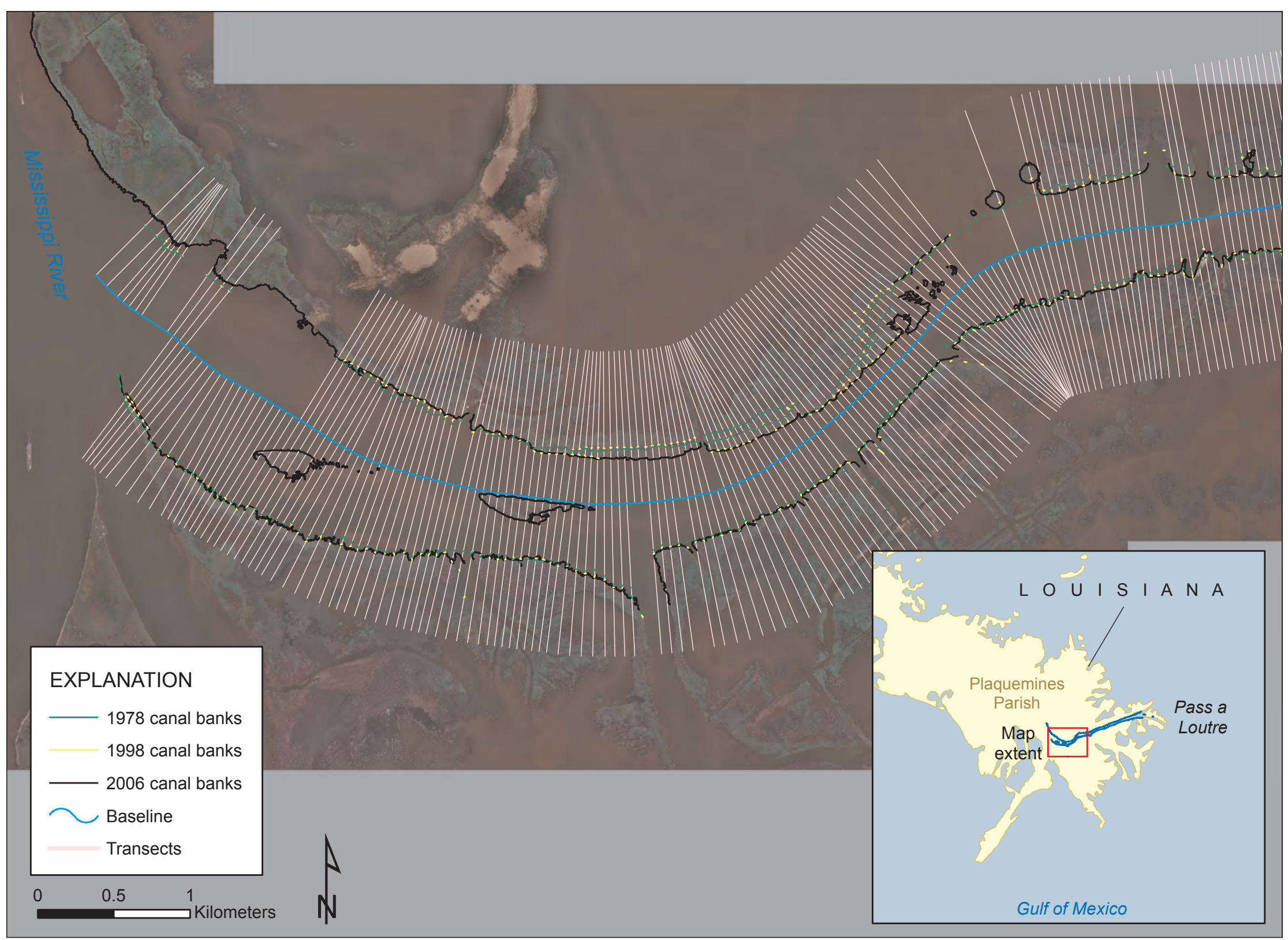

Figure 1-26. Pass a Loutre channel, La. (map 1 of 3), showing canal bank positions digitized for three different time periods. Transects were generated at 50-m intervals to measure erosion rates from 1978-2006 within navigation canals in the Gulf of Mexico. The background imagery consists of 2006 aerial photographs. 




Figure 1-27. Pass a Loutre channel, La. (map 2 of 3), showing canal bank positions digitized for three different time periods. Transects were generated at 50-m intervals to measure erosion rates from 1978-2006 within navigation canals in the Gulf of Mexico. The background imagery consists of 2006 aerial photographs. 


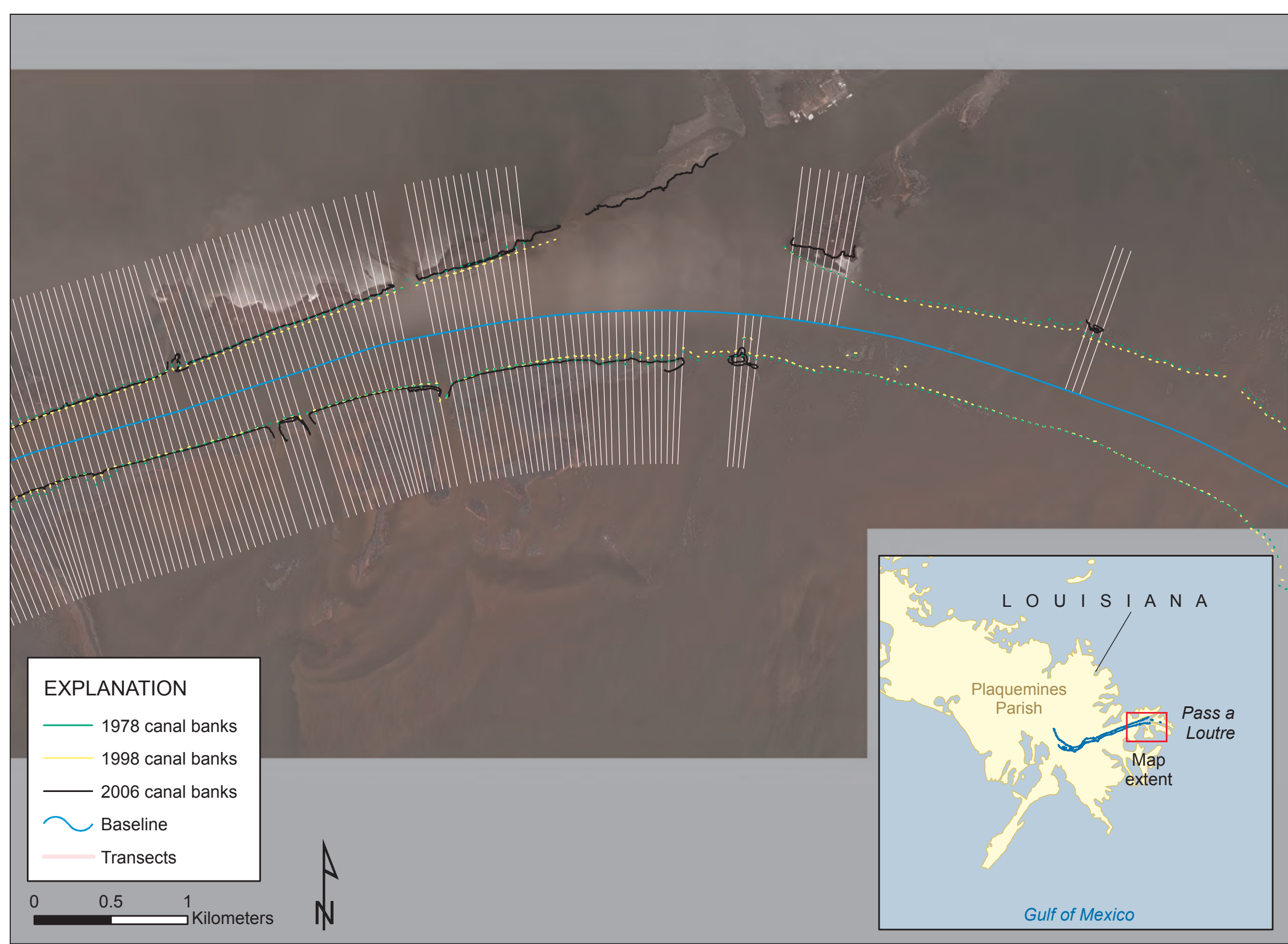

Figure 1-28. Pass a Loutre channel, La. (map 3 of 3), showing canal bank positions digitized for three different time periods. Transects were generated at $50-\mathrm{m}$ intervals to measure erosion rates from 1978-2006 within navigation canals in the Gulf of Mexico. The background imagery consists of 2006 aerial photographs. 


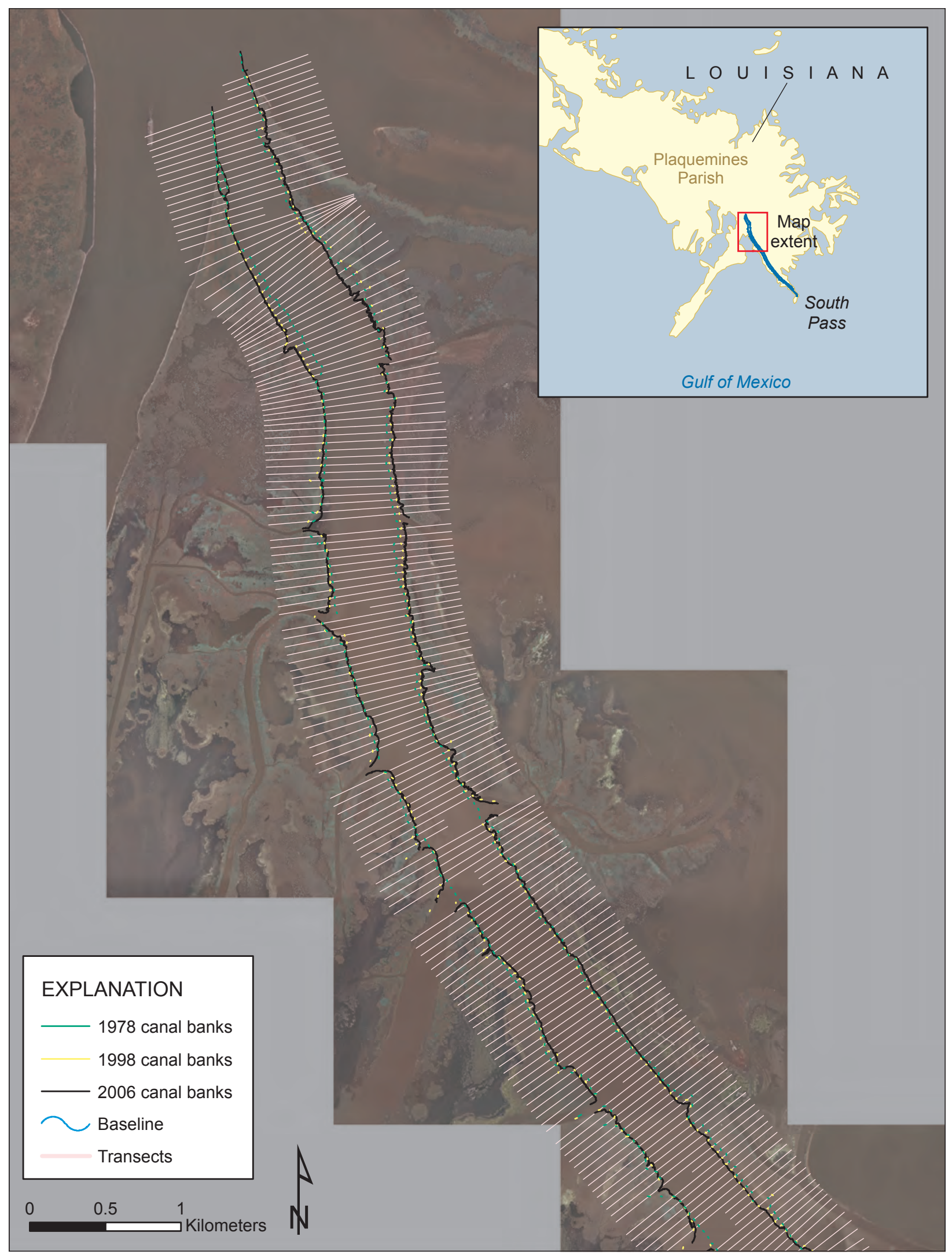

Figure 1-29. South Pass channel, La. (map 1 of 3), showing canal bank positions digitized for three different time periods. Transects were generated at 50-m intervals to measure erosion rates from 1978-2006 within navigation canals in the Gulf of Mexico. The background imagery consists of 2006 aerial photographs. 




Figure 1-30. South Pass channel, La. (map 2 of 3), showing canal bank positions digitized for three different time periods. Transects were generated at 50-m intervals to measure erosion rates from 1978-2006 within navigation canals in the Gulf of Mexico. The background imagery consists of 2006 aerial photographs. 


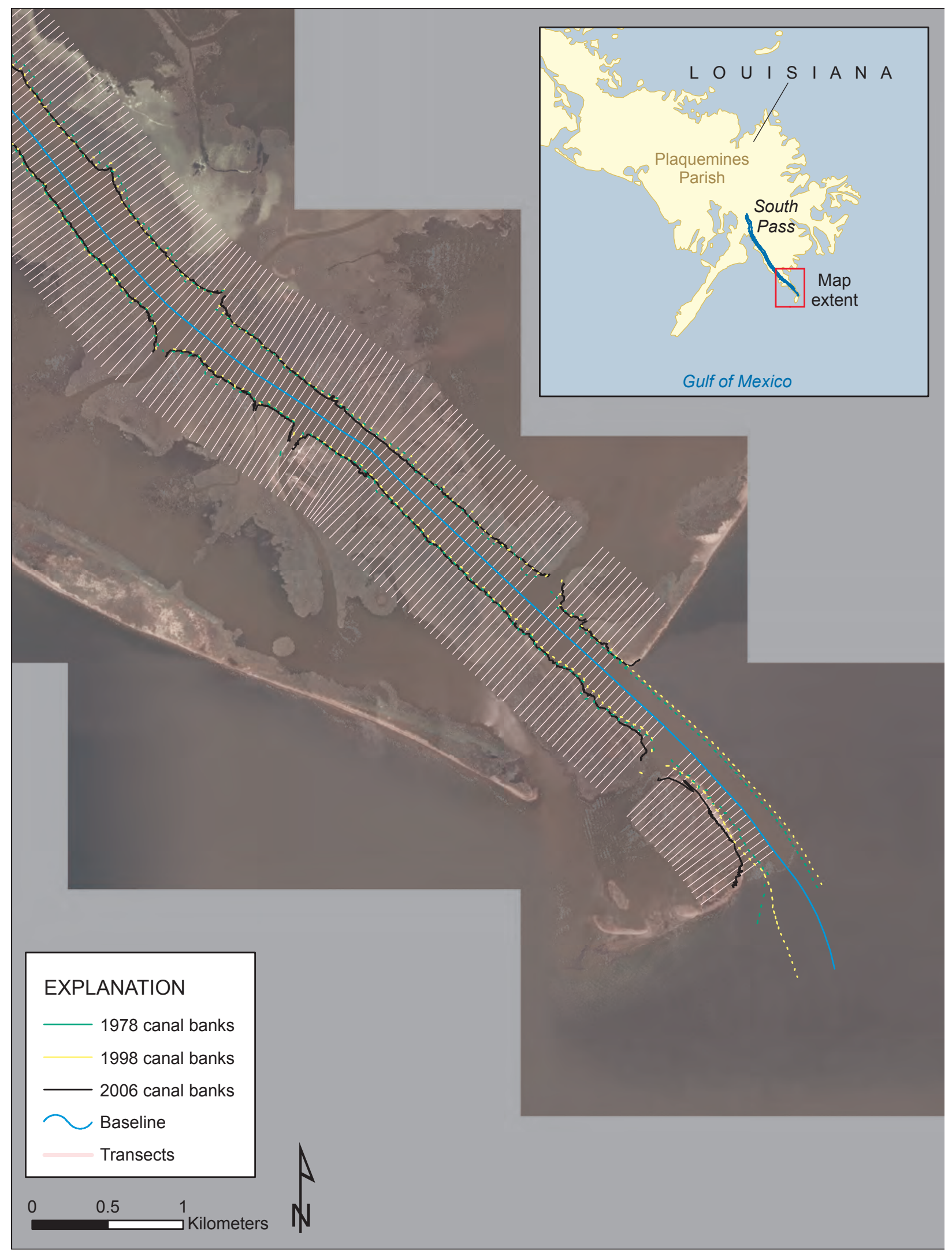

Figure 1-31. South Pass channel, La. (map 3 of 3), showing canal bank positions digitized for three different time periods. Transects were generated at 50-m intervals to measure erosion rates from 1978-2006 within navigation canals in the Gulf of Mexico. The background imagery consists of 2006 aerial photographs. 


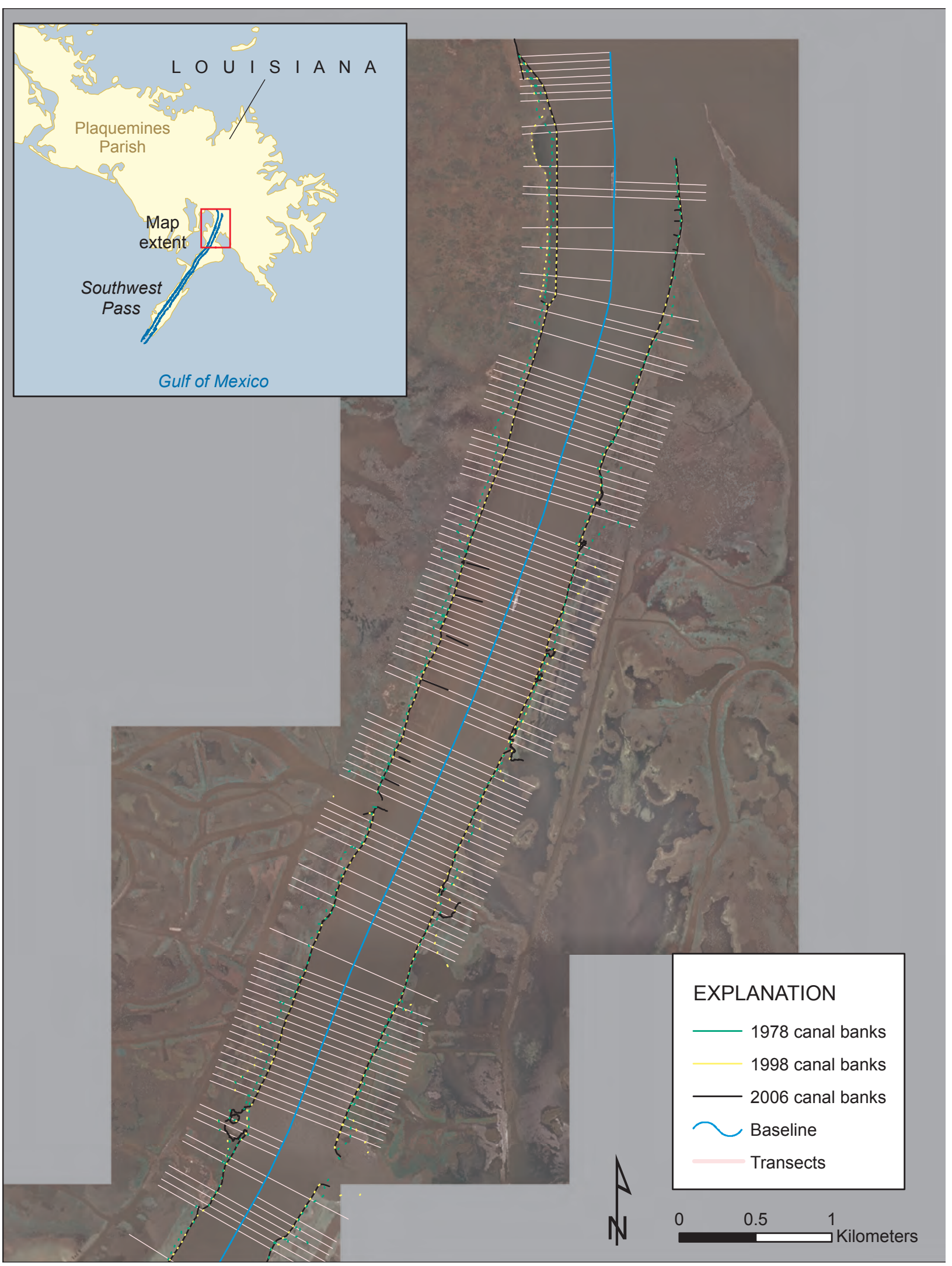

Figure 1-32. Southwest Pass channel, La. (map 1 of 4), showing canal bank positions digitized for three different time periods. Transects were generated at 50-m intervals to measure erosion rates from 1978-2006 within navigation canals in the Gulf of Mexico. The background imagery consists of 2006 aerial photographs. 


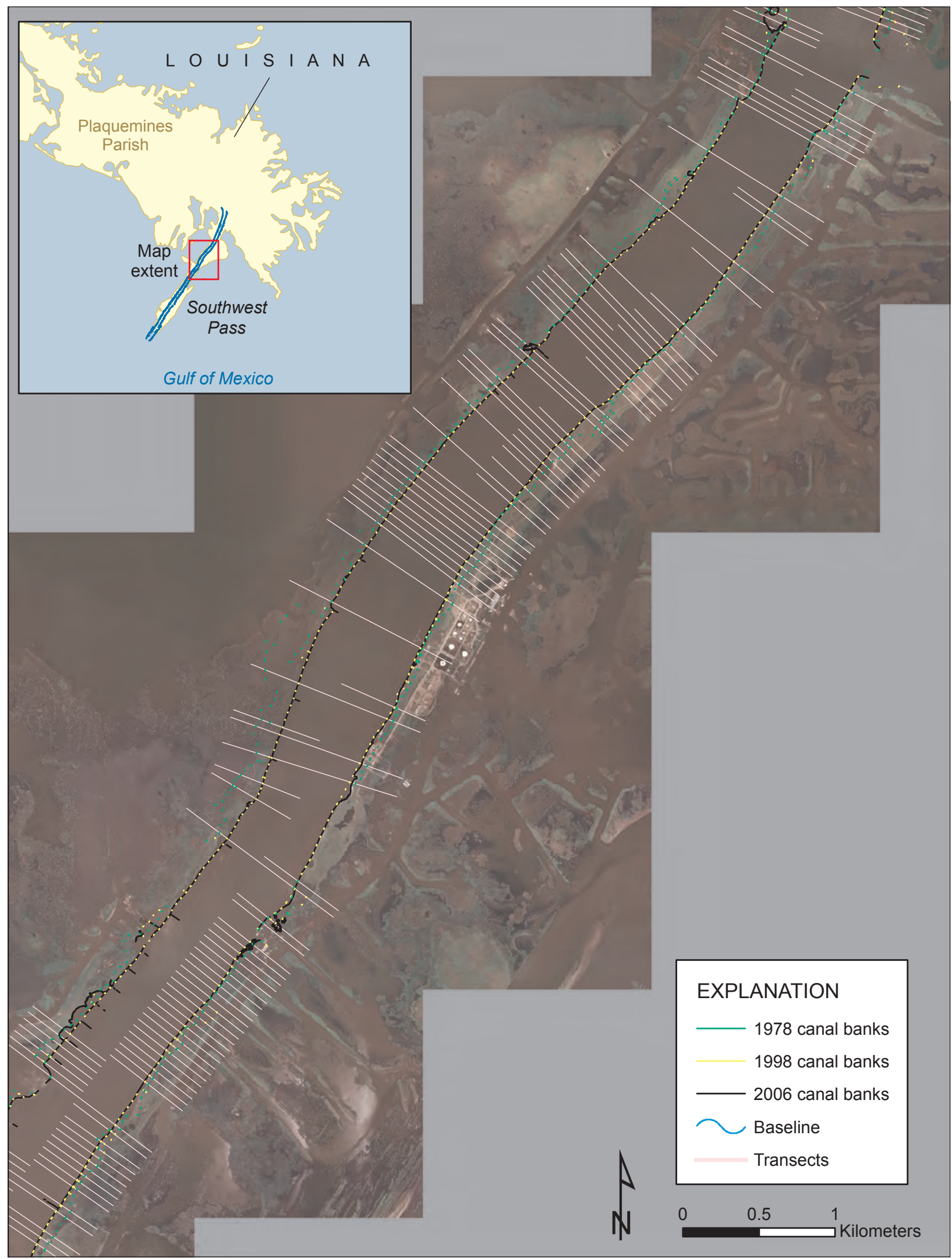

Figure 1-33. Southwest Pass channel, La. (map 2 of 4), showing canal bank positions digitized for three different time periods. Transects were generated at 50-m intervals to measure erosion rates from 1978-2006 within navigation canals in the Gulf of Mexico. The background imagery consists of 2006 aerial photographs. 


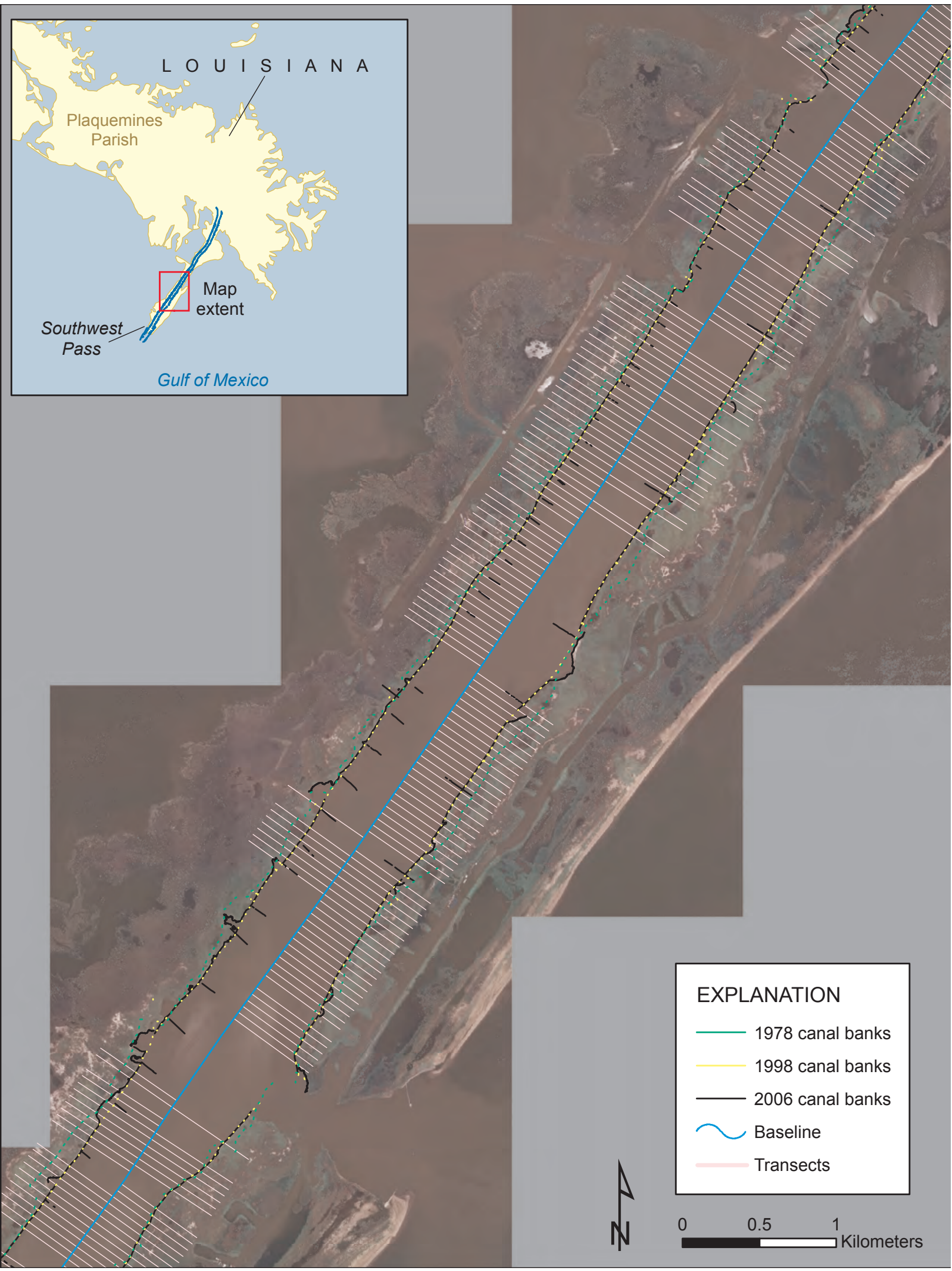

Figure 1-34. Southwest Pass channel, La. (map 3 of 4), showing canal bank positions digitized for three different time periods. Transects were generated at 50-m intervals to measure erosion rates from 1978-2006 within navigation canals in the Gulf of Mexico. The background imagery consists of 2006 aerial photographs. 


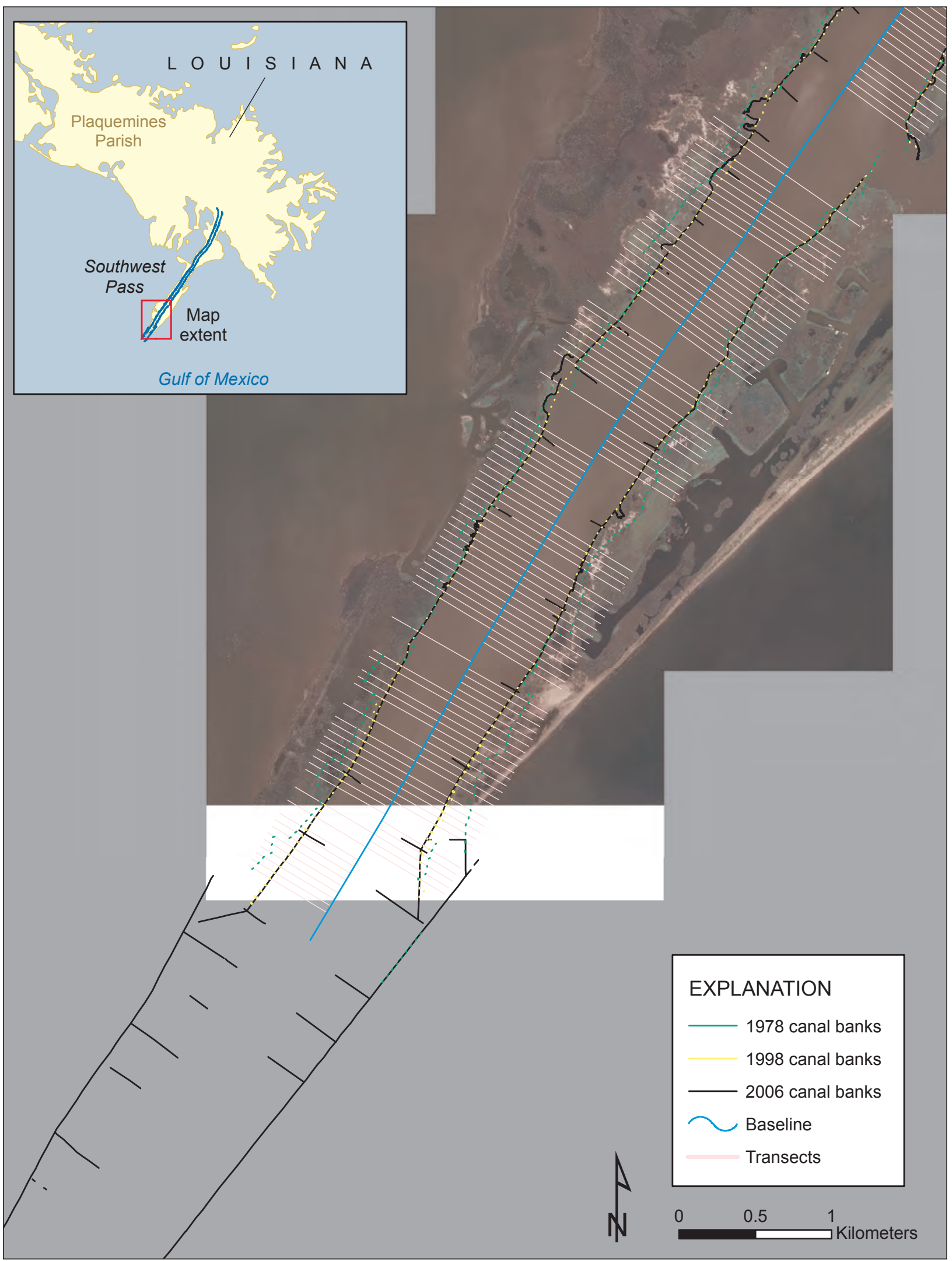

Figure 1-35. Southwest Pass channel, La. (map 4 of 4), showing canal bank positions digitized for three different time periods. Transects were generated at 50-m intervals to measure erosion rates from 1978-2006 within navigation canals in the Gulf of Mexico. The background imagery consists of 2006 aerial photographs. 


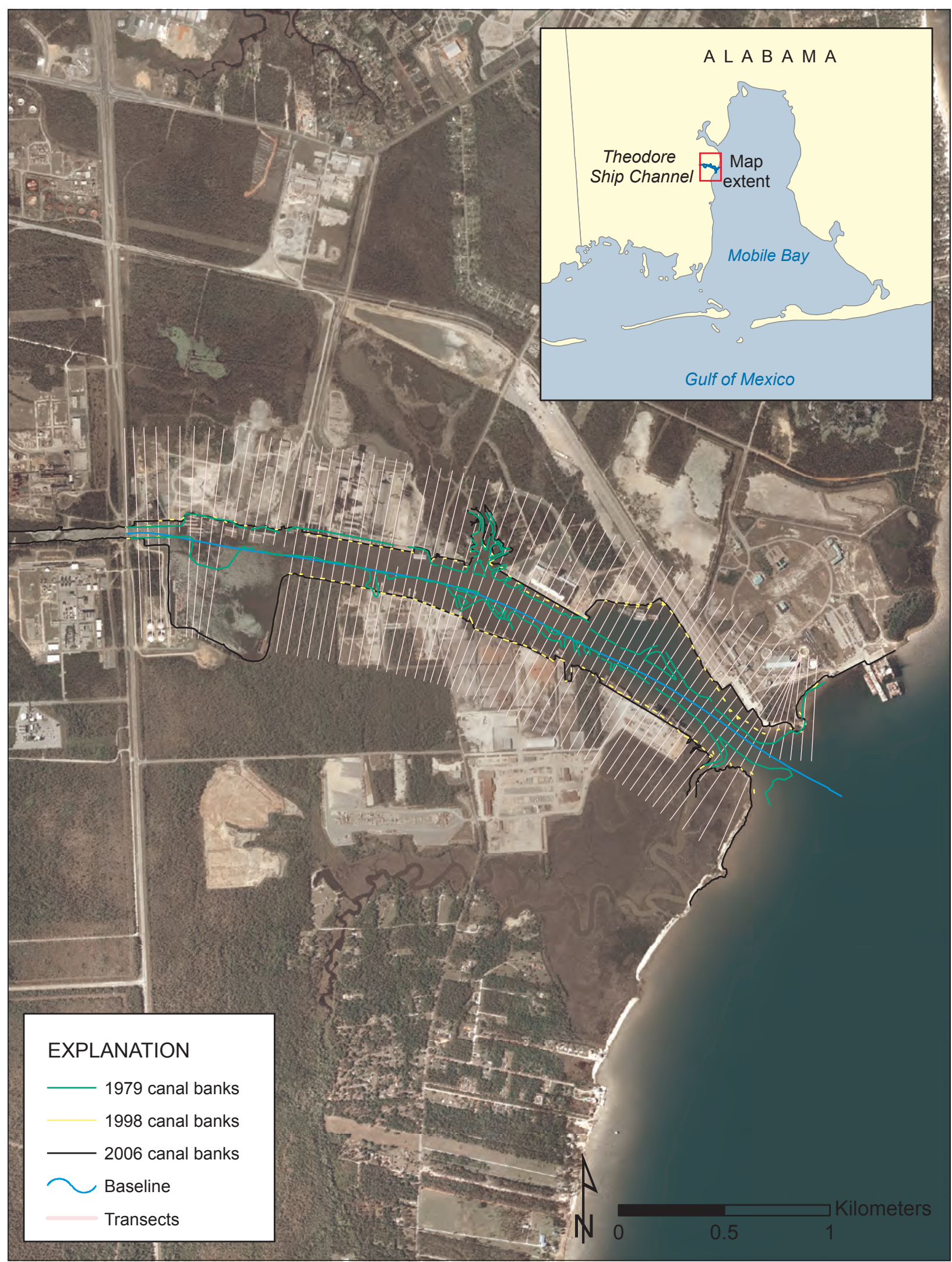

Figure 1-36. Theodore Ship Channel, Ala. (map 1 of 1), showing canal bank positions digitized for three different time periods. Transects were generated at 50-m intervals to measure erosion rates from 1979-2006 within navigation canals in the Gulf of Mexico. The background imagery consists of 2006 aerial photographs. 


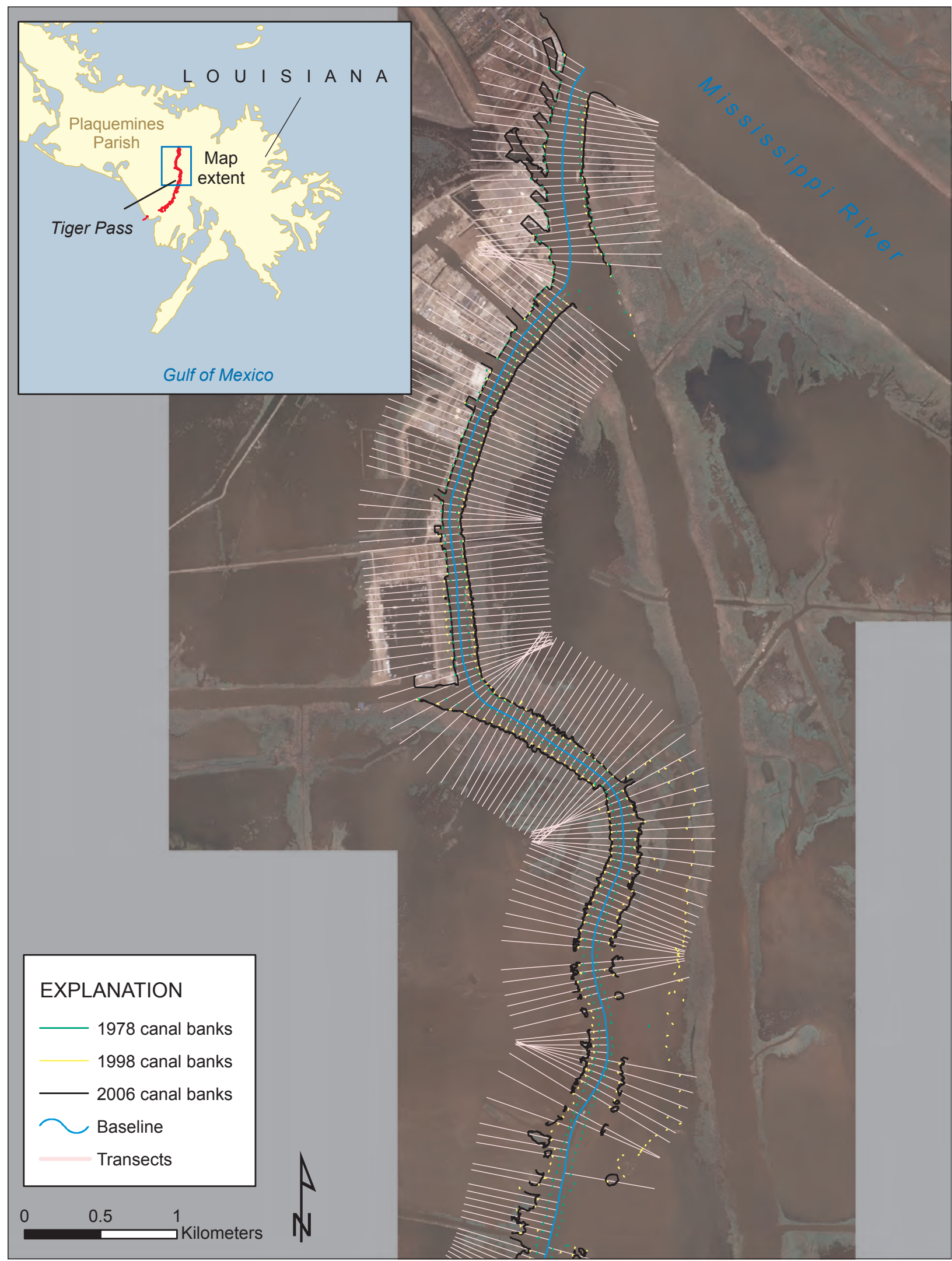

Figure 1-37. Tiger Pass channel, La. (map 1 of 2), showing canal bank positions digitized for three different time periods. Transects were generated at 50-m intervals to measure erosion rates from 1978-2006 within navigation canals in the Gulf of Mexico. The background imagery consists of 2006 aerial photographs. 


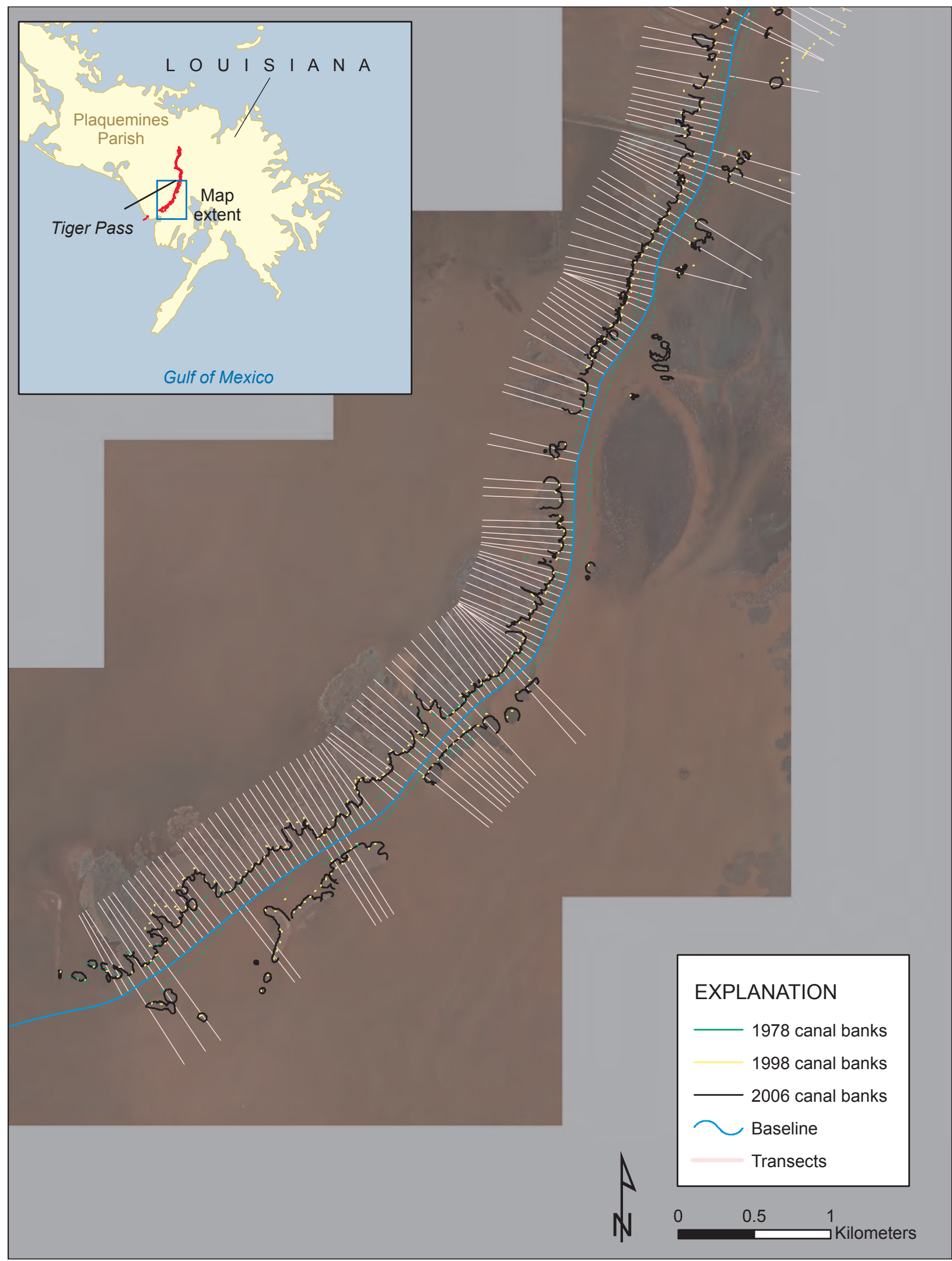

Figure 1-38. Tiger Pass channel, La. (map 2 of 2), showing canal bank positions digitized for three different time periods. Transects were generated at 50-m intervals to measure erosion rates from 1978-2006 within navigation canals in the Gulf of Mexico. The background imagery consists of 2006 aerial photographs. 



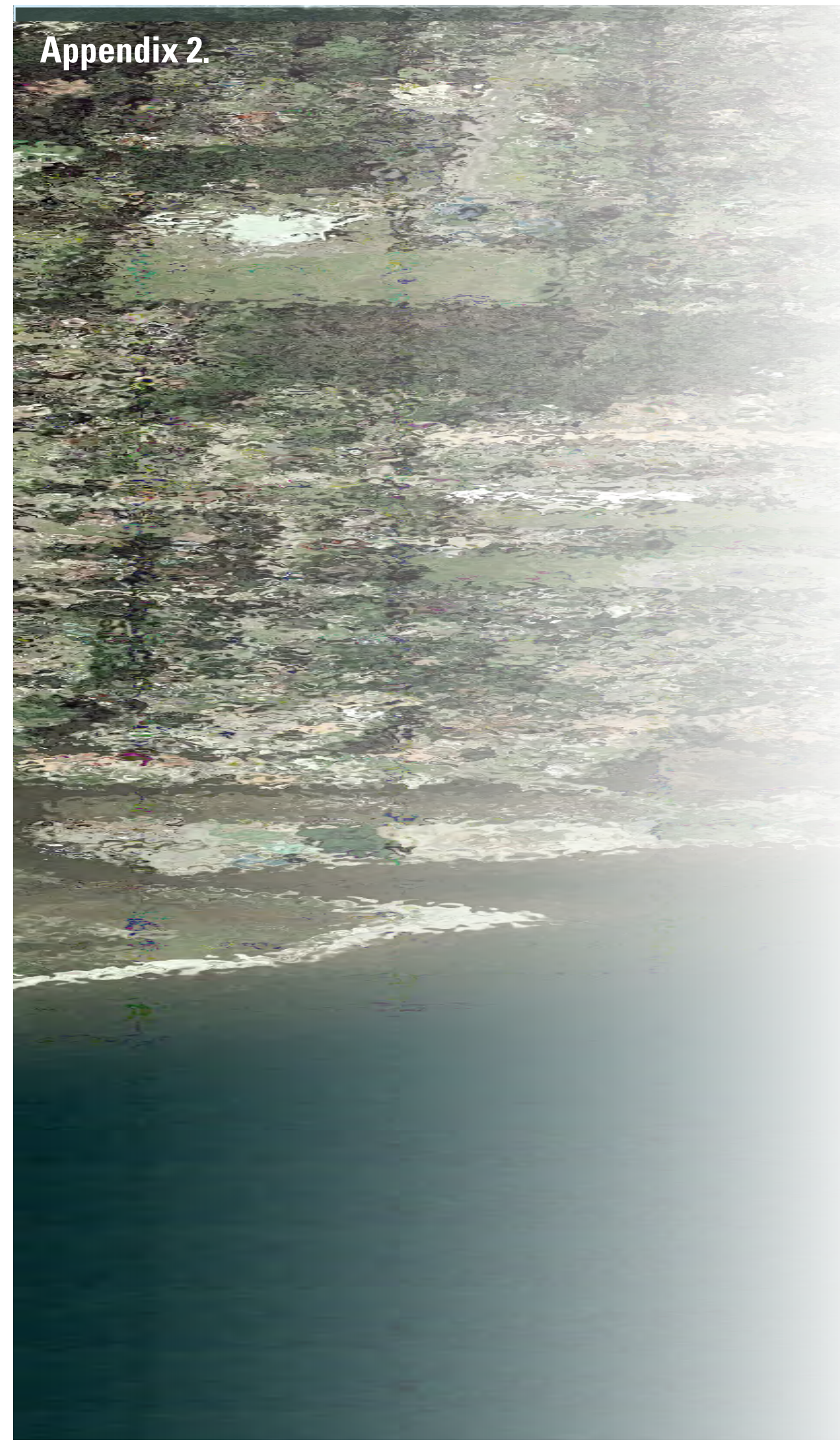






Figure 2-1. Rates of shoreline change for the Atchafalaya River navigation canal, La., 1978-2005 (map 1 of 4). Rates were derived by using linear regression analysis. The background imagery consists of 2005 aerial photographs. 




Figure 2-2. Shoreline change rates based on linear regression analysis for the Atchafalaya River, La., navigation canal, 1978-2005 (map 2 of 4). The background imagery consists of 2005 aerial photographs. 


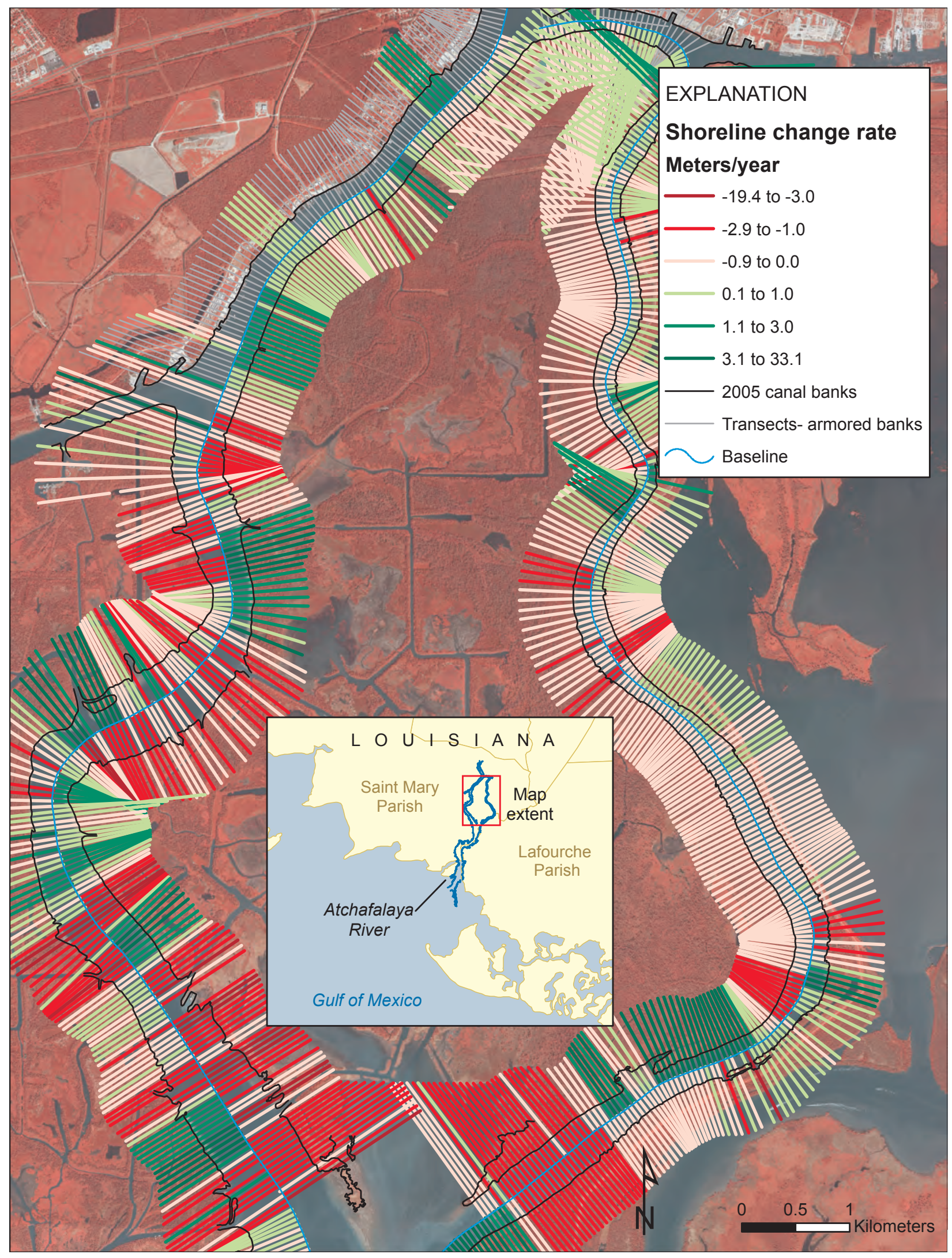

Figure 2-3. Shoreline change rates based on linear regression analysis for the Atchafalaya River, La., navigation canal, 1978-2005 (map 3 of 4). The background imagery consists of 2005 aerial photographs. 




Figure 2-4. Shoreline change rates based on linear regressio analysis for the Atchafalaya River, La., navigation canal, 1978-2005 (map 4 of 4). The background imagery consists of 2005 aerial photographs. 


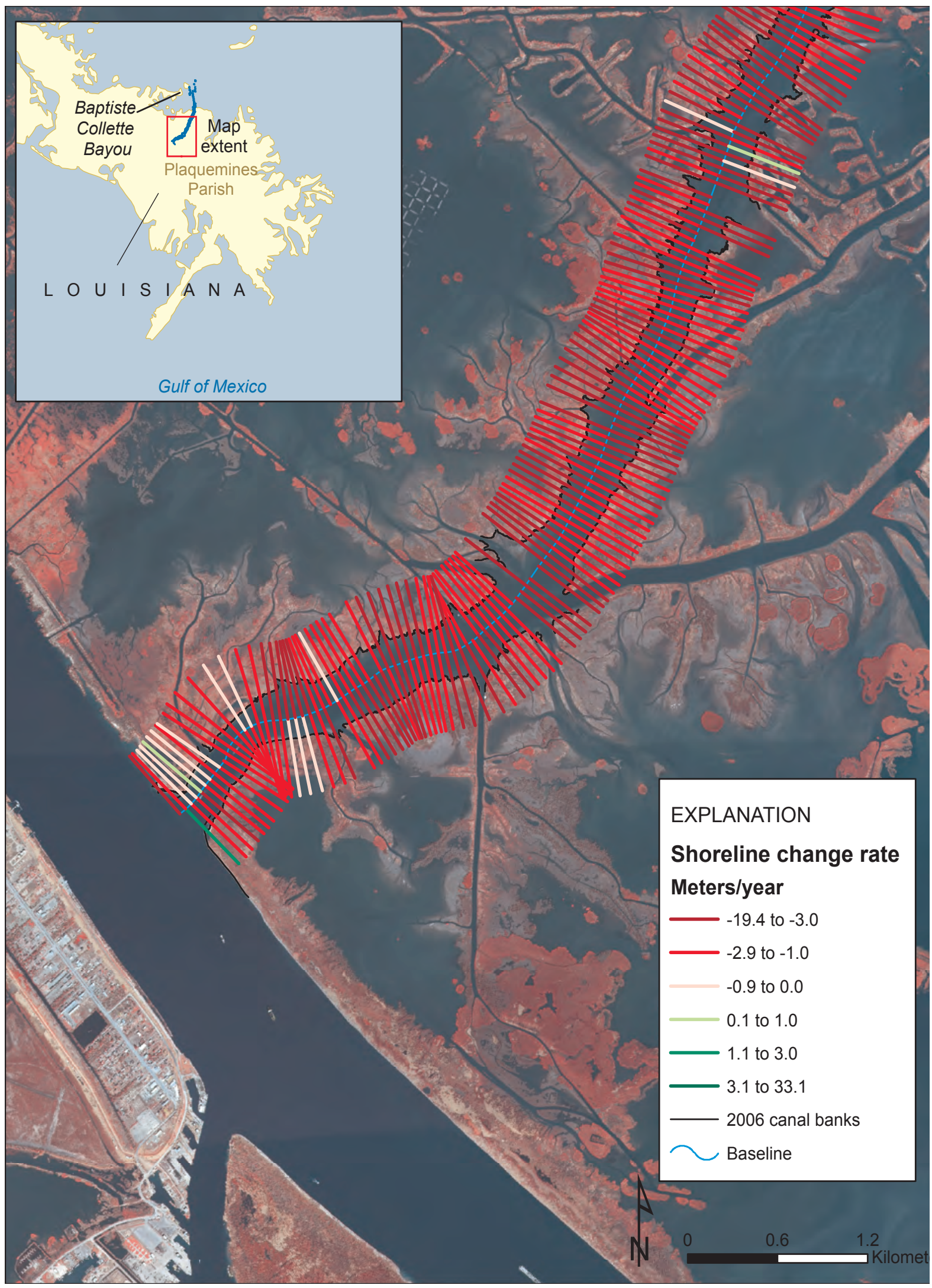

Figure 2-5. Shoreline change rates based on linear regression analysis for the Baptiste Collette Bayou channel, La., 1978-2006 (map 1 of 2). The background imagery consists of 2005 aerial photographs. 


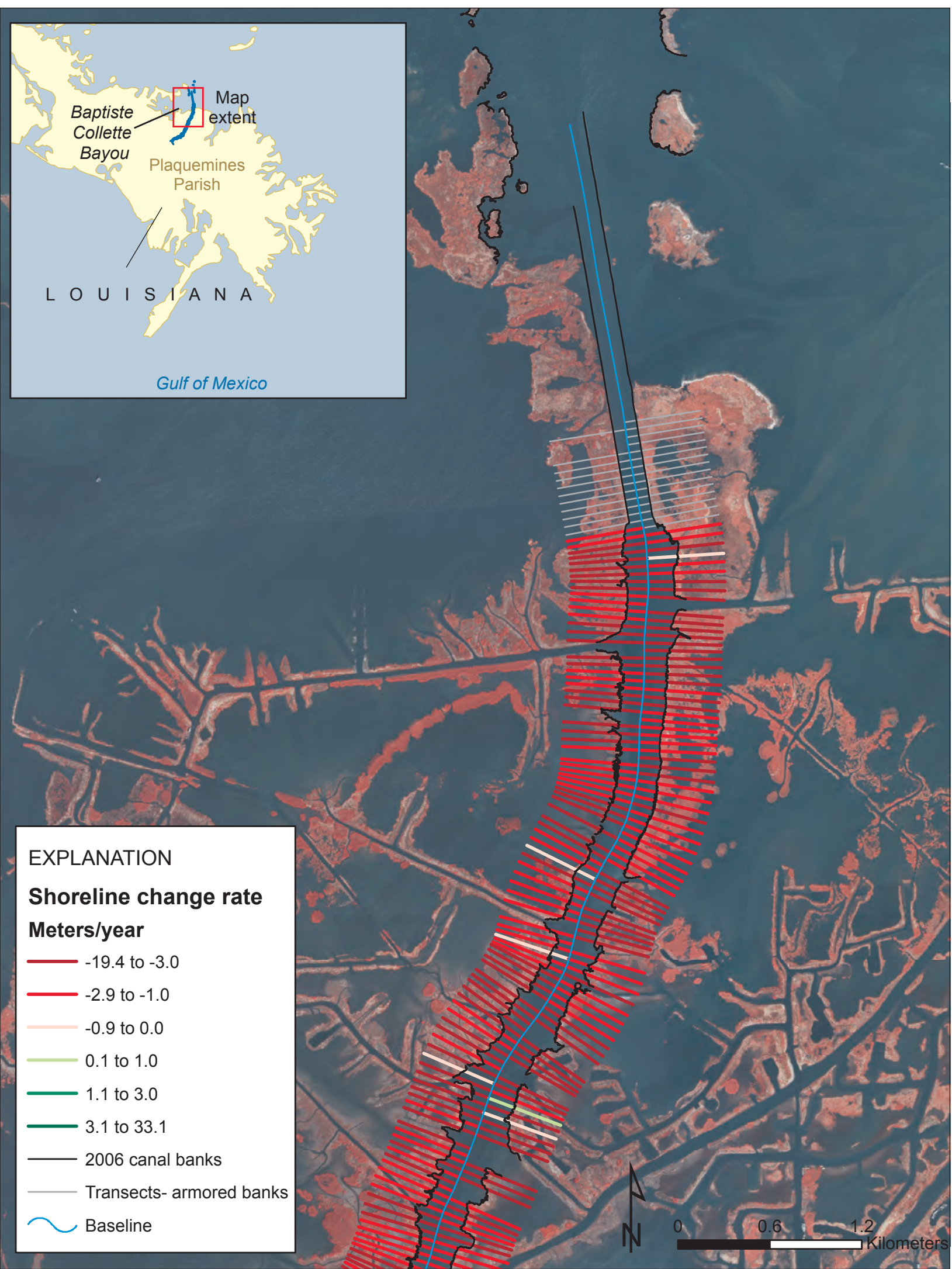

Figure 2-6. Shoreline change rates based on linear regression analysis for the Baptiste Collette Bayou, La., navigation canal, 1978-2006 (map 2 of 2). The background imagery consists of 2005 aerial photographs. 




Figure 2-7. Shoreline change rates based on linear regression analysis for the Bayou Lafourche Cutoff, La., 1978-2006 (map 1 of 2). The background imagery consists of 2005 aerial photographs. 


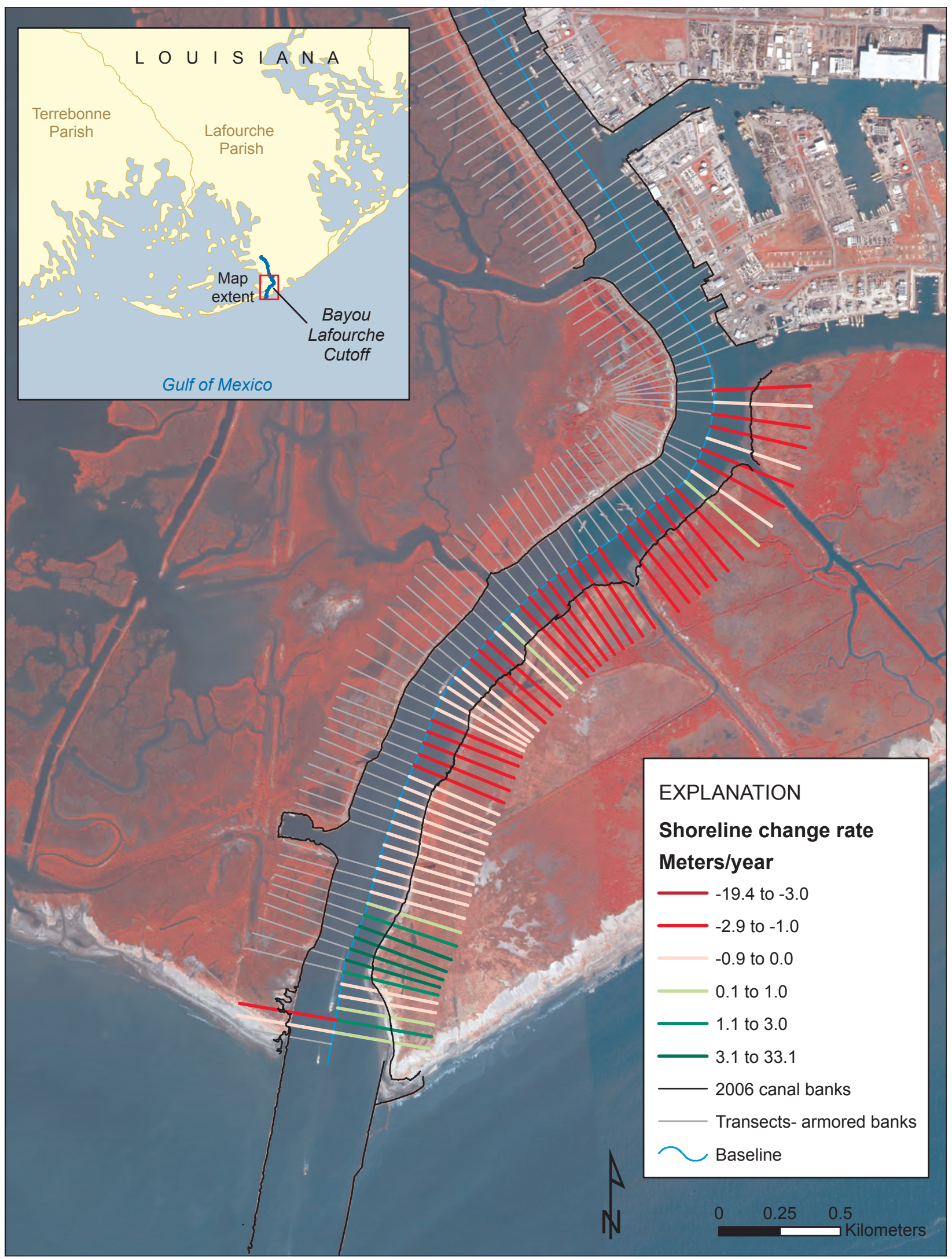

Figure 2-8. Shoreline change rates based on linear regression analysis for the Bayou LaFourche Cutoff, La., navigation canal, 1978-2006 (map 2 of 2). The background imagery consists of 2005 aerial photographs. 


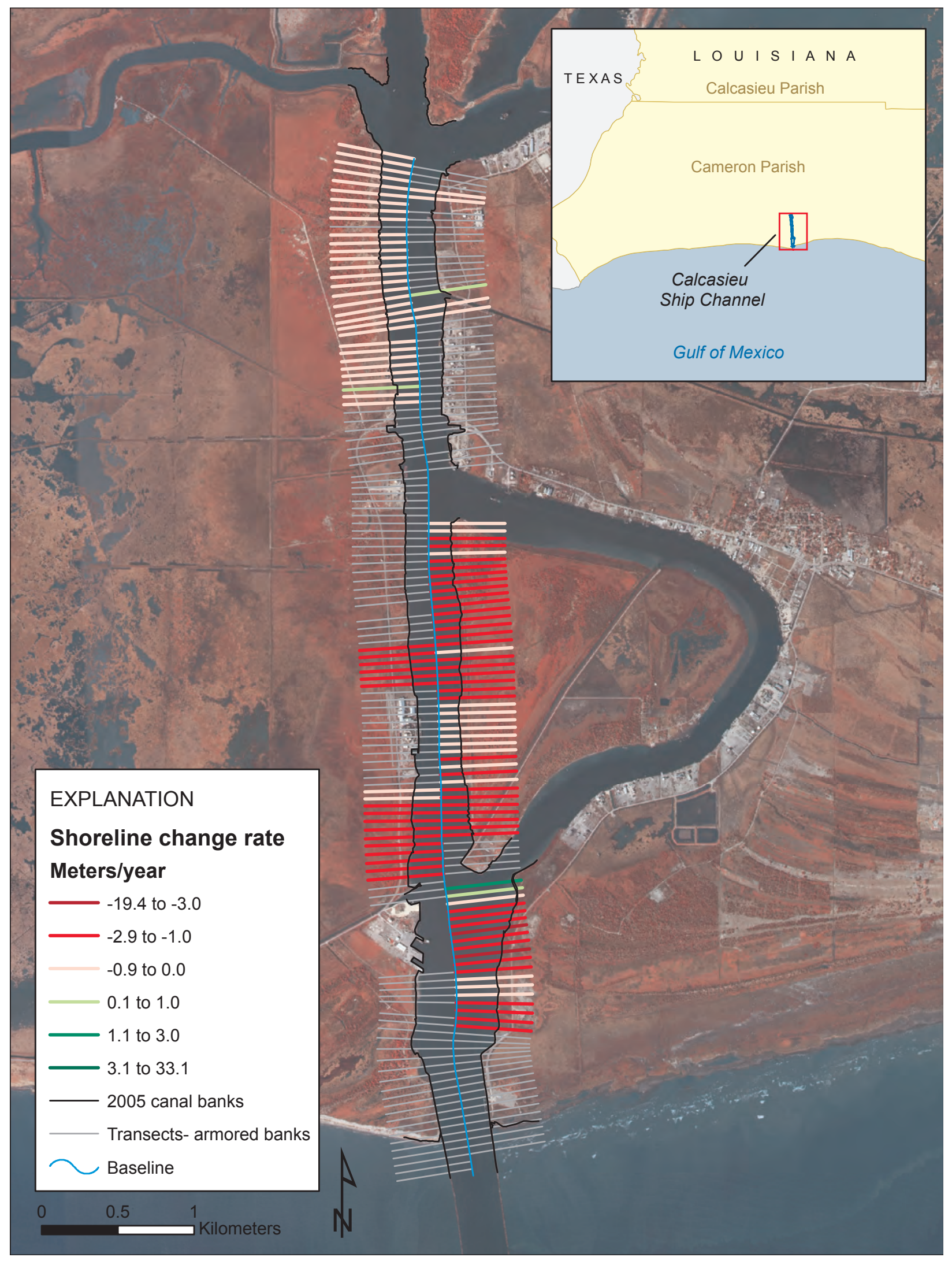

Figure 2-9. Shoreline change rates based on linear regression analysis for the Calcasieu Ship Channel, La., 1978-2005 (map 1 of 1) The background imagery consists of 2005 aerial photographs. 




Figure 2-10. Shoreline change rates based on linear regression analysis for the Freeport Harbor Channel, Tex., 1979-2006 (map 1 of 1). The background imagery consists of 2006 aerial photographs. 




Figure 2-11. Shoreline change rates based on linear regression analysis for the Freshwater Bayou Channel, La., 1978-2005 (map 1 of 4). The background imagery consists of 2005 aerial photographs. 


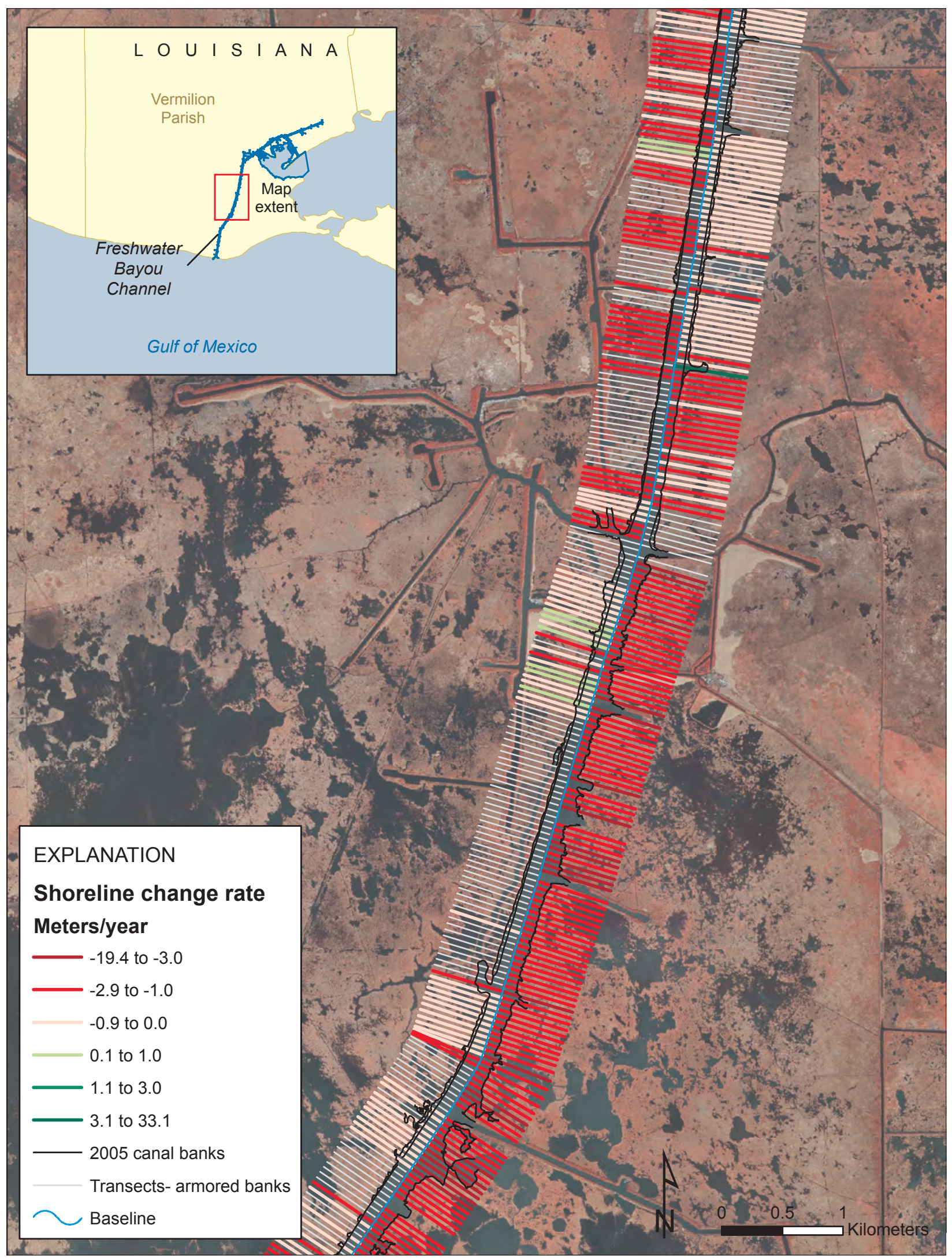

Figure 2-12. Shoreline change rates based on linear regression analysis for the Freshwater Bayou Channel, La., navigation canal, 1978-2005 (map 2 of 4). The background imagery consists of 2005 aerial photographs. 


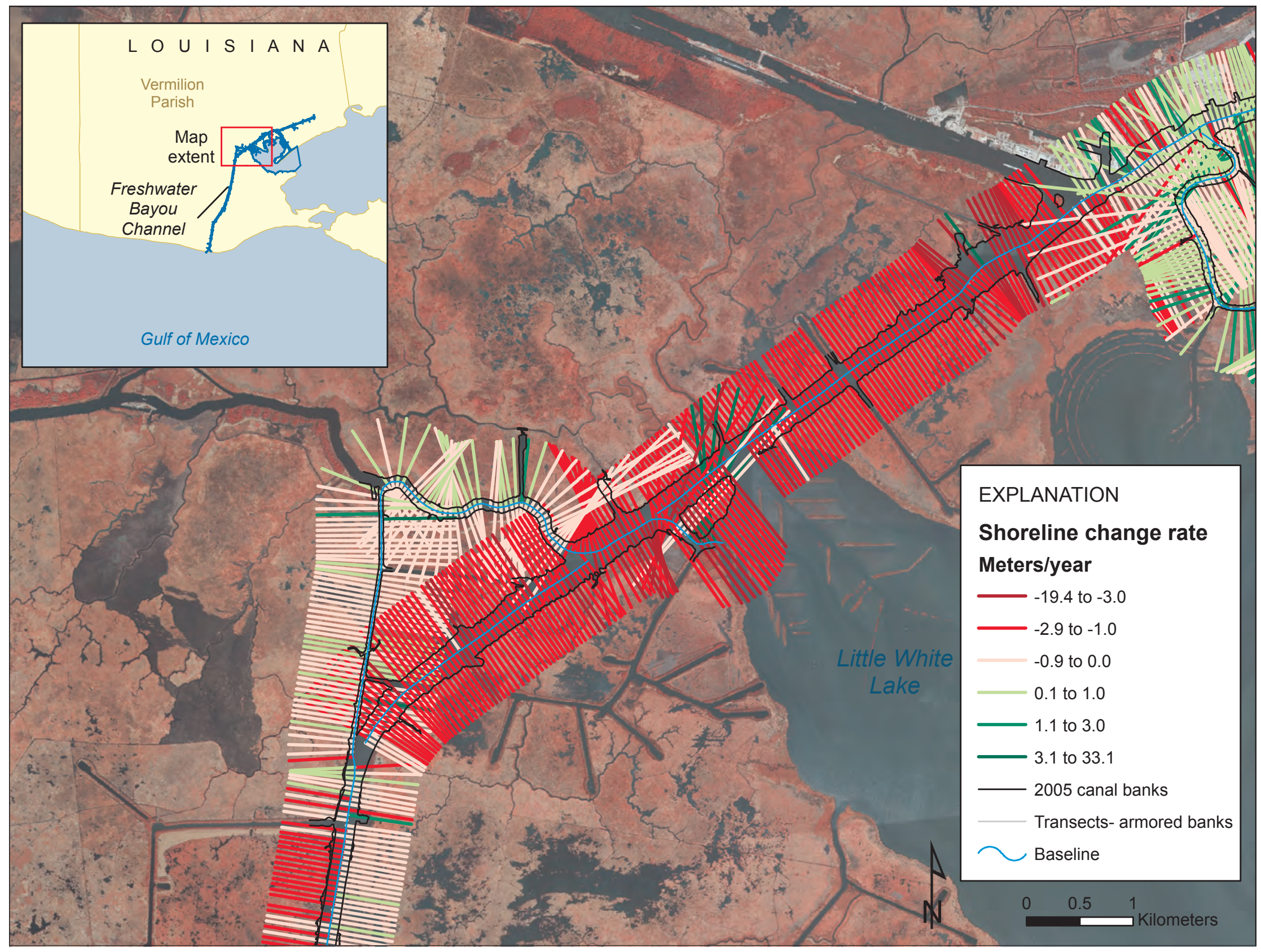

Figure 2-13. Shoreline change rates based on linear regression analysis for the Freshwater Bayou Channel, La., navigation canal, 1978-2005 (map 3 of 4). The background imagery consists of 2005 aerial photographs. 


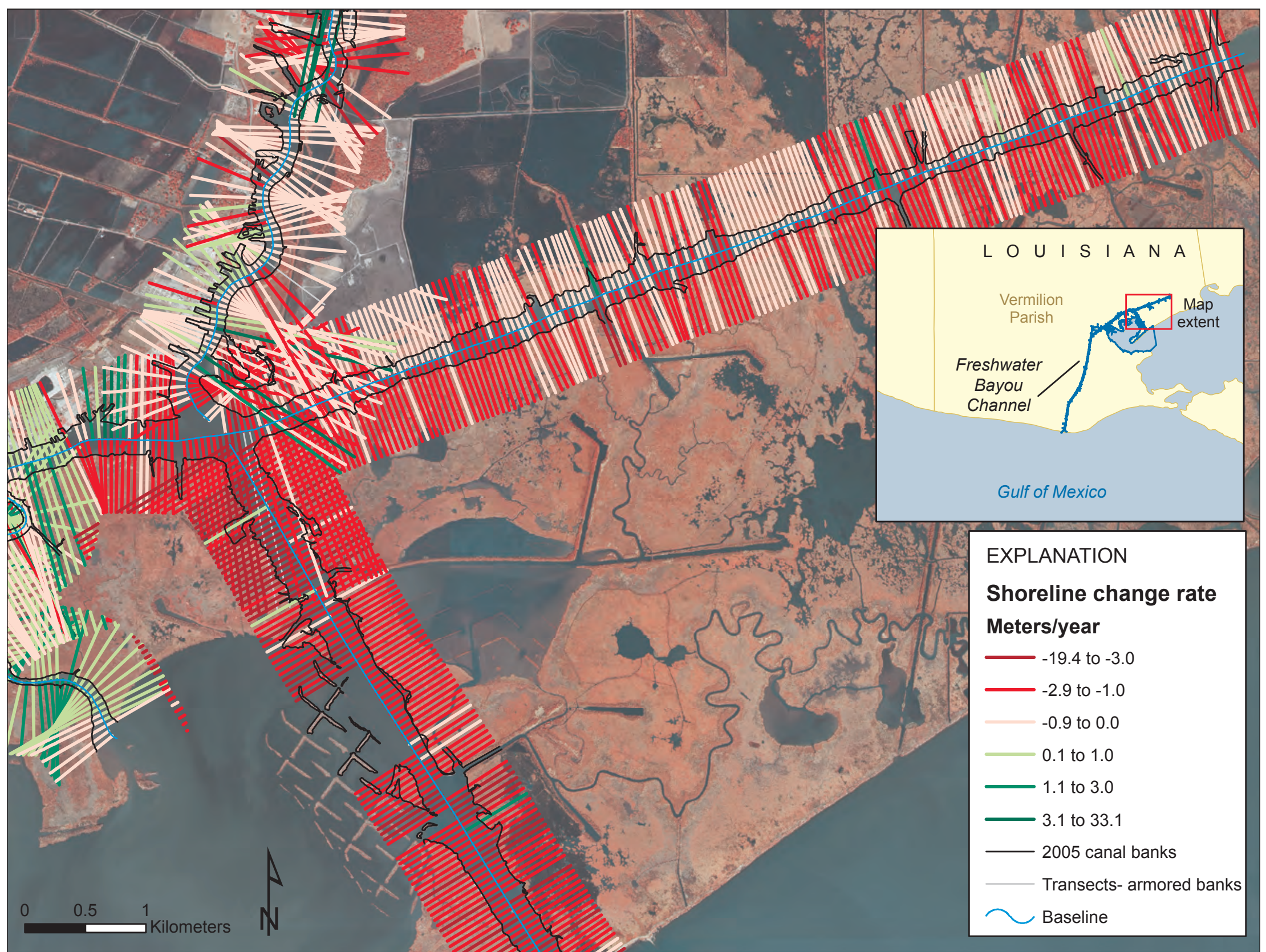

Figure 2-14. Shoreline change rates based on linear regression analysis for the Freshwater Bayou Channel, La., navigation canal, 1978-2005 (map 4 of 4). The background imagery consists of 2005 aerial photographs. 


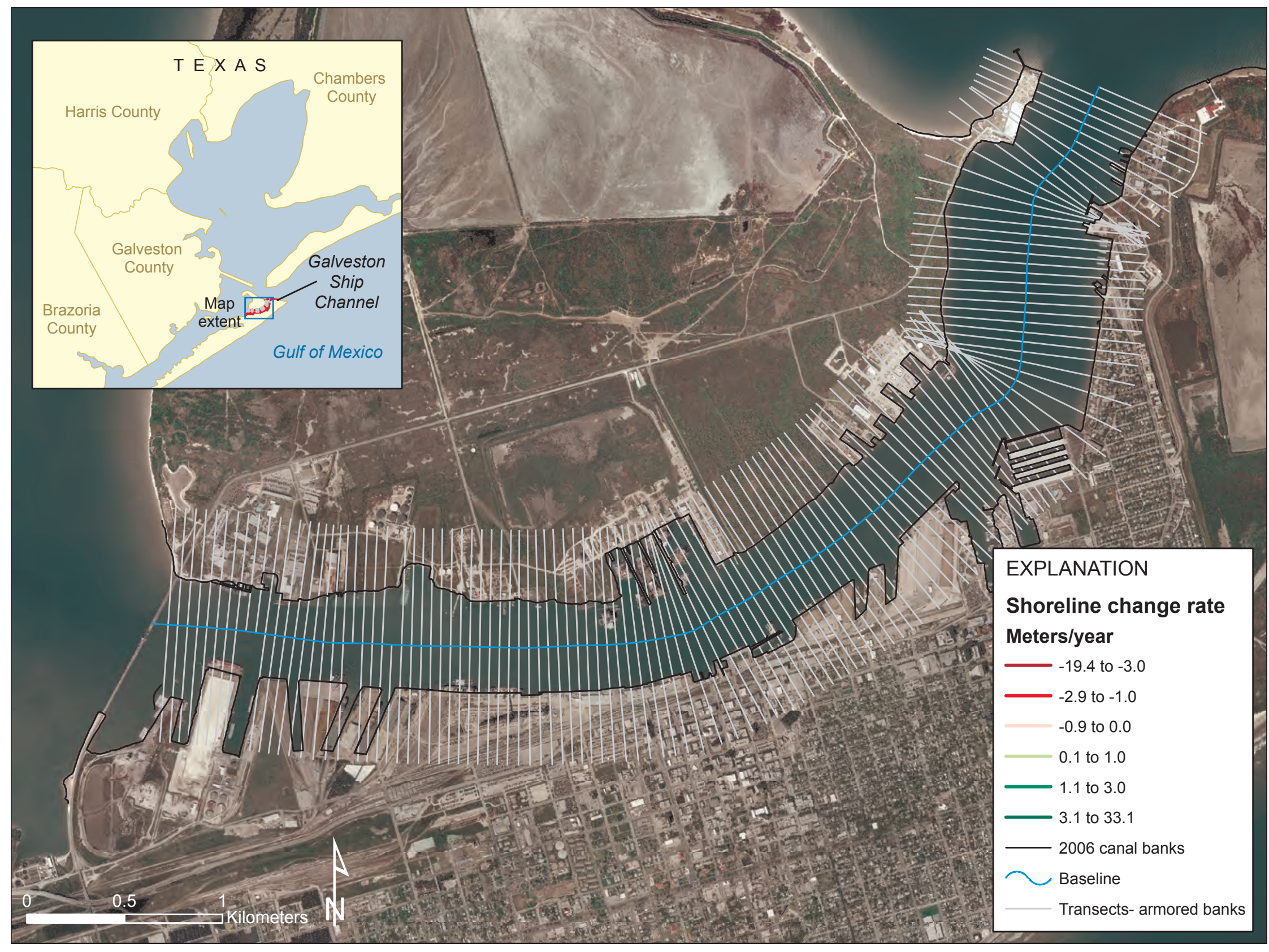

Figure 2-15. Shoreline change rates based on linear regression analysis for the Galveston Ship Channel, Tex., 1979-2006 (map 1 of 1). The background imagery consists of 2006 aerial photographs. 


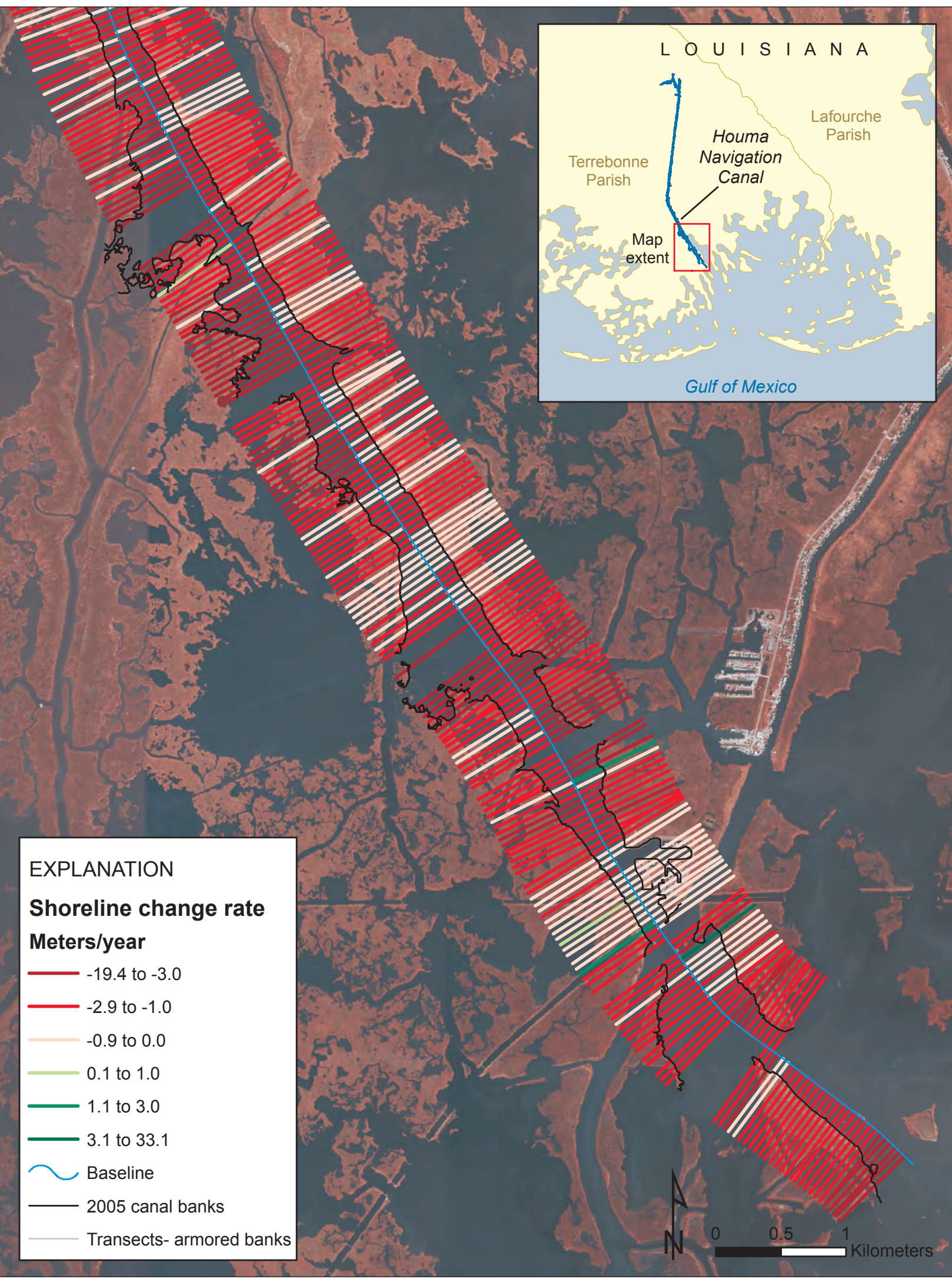

Figure 2-16. Shoreline change rates based on linear regression analysis for the Houma Navigation Canal, La., 1978-2005 (map 1 of 4). The background imagery consists of 2005 aerial photographs. 


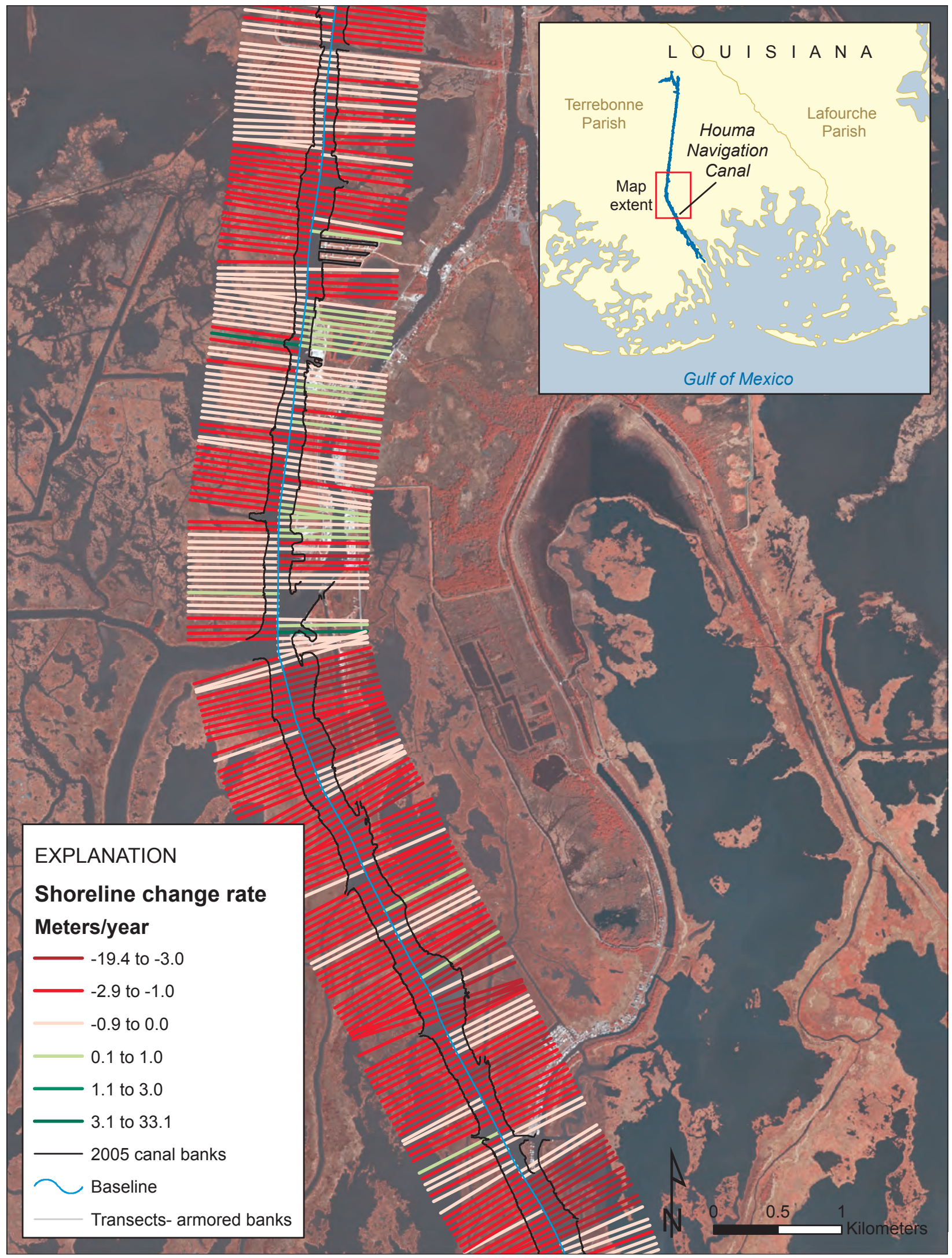

Figure 2-17. Shoreline change rates based on linear regression analysis for the Houma Navigation Canal, La., 1978-2005 (map 2 of 4). The background imagery consists of 2005 aerial photographs. 


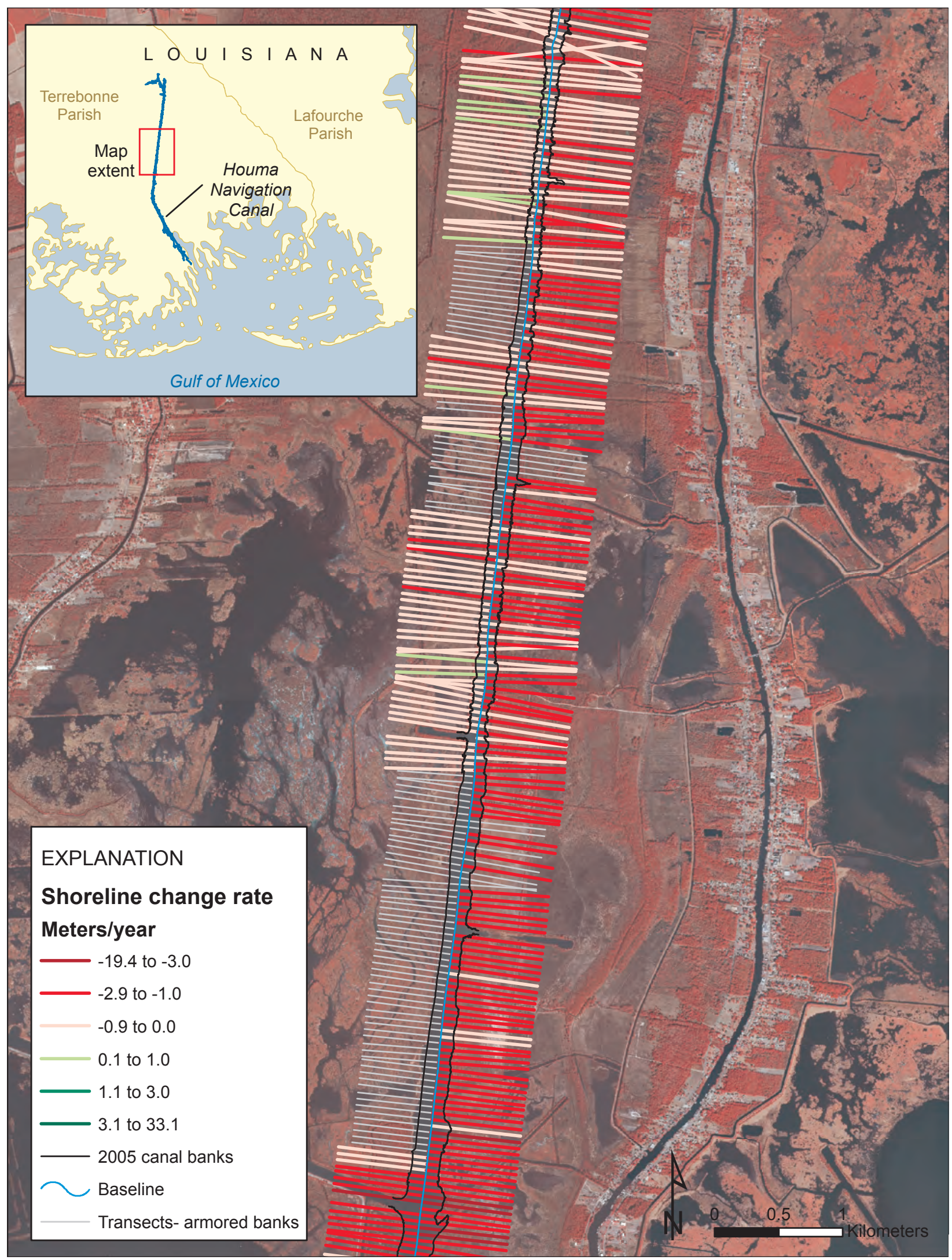

Figure 2-18. Shoreline change rates based on linear regression analysis for the Houma Navigation Canal, La., 1978-2005 (map 3 of 4). The background imagery consists of 2005 aerial photographs. 


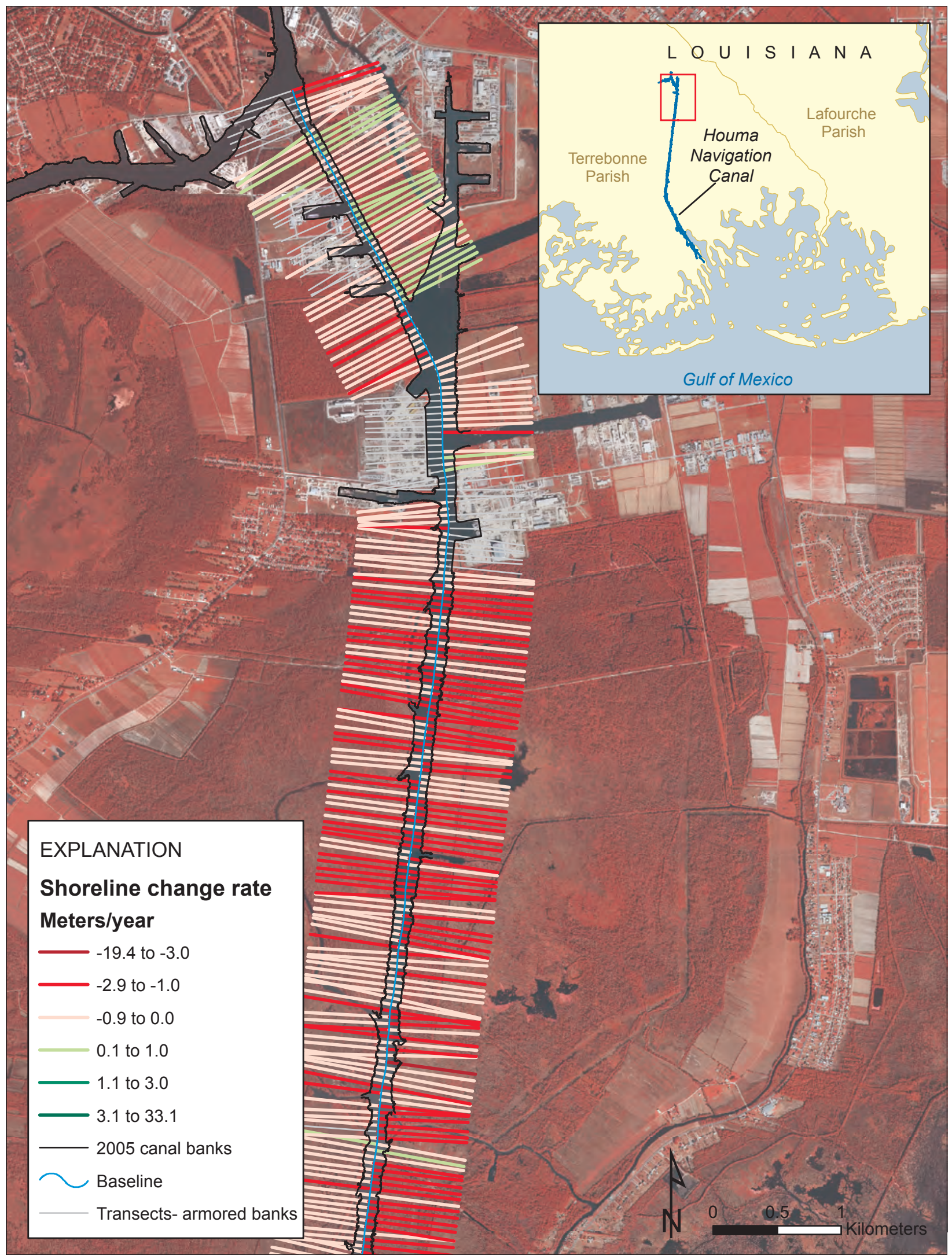

Figure 2-19. Shoreline change rates based on linear regression analysis for the Houma Navigation Canal, La., 1978-2005 (map 4 of 4). The background imagery consists of 2005 aerial photographs. 




Figure 2-20. Shoreline change rates based on linear regression analysis for the Main Pass channel, La., 1978-2006 (map 1 of 3). The background imagery consists of 2005 aerial photographs. 


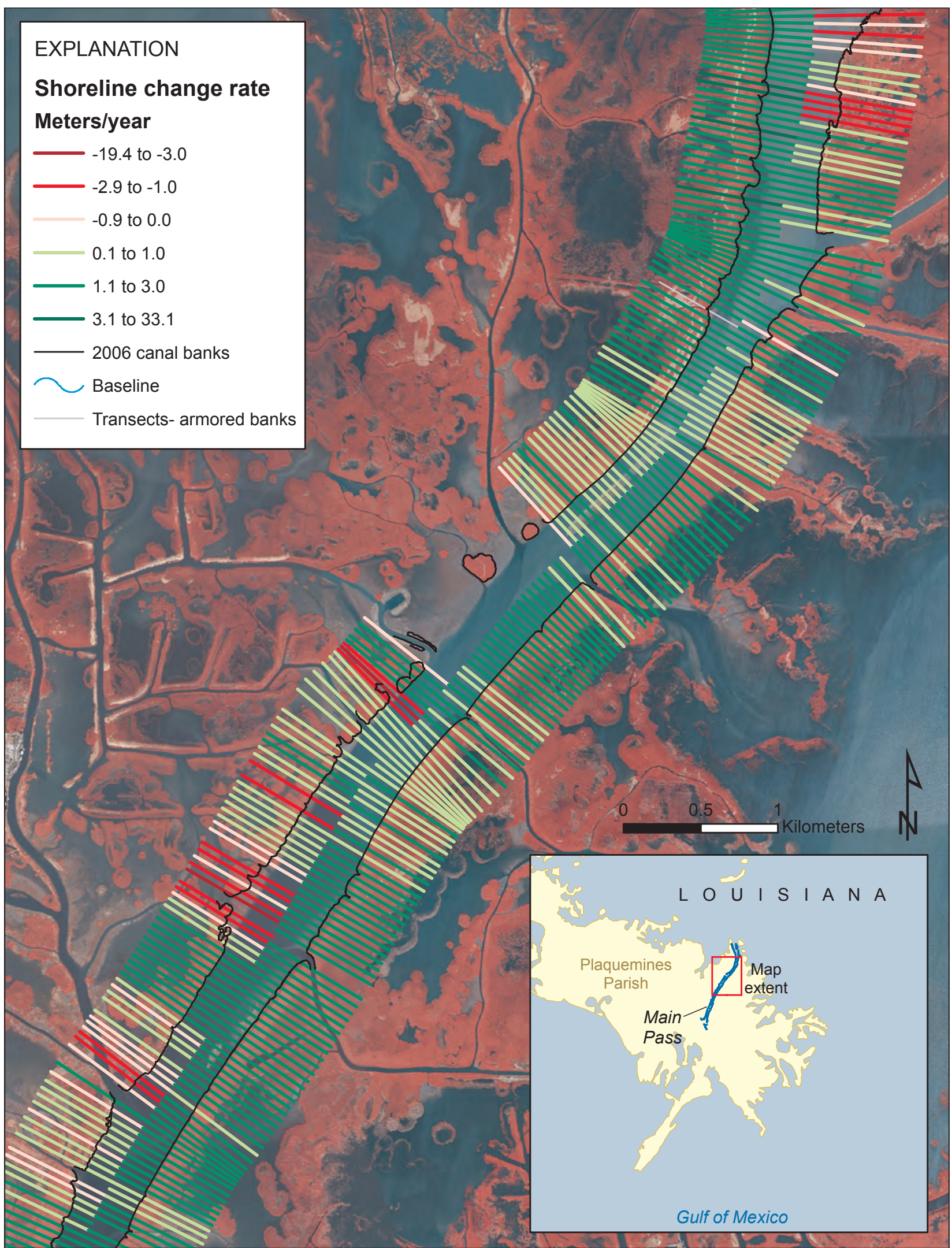

Figure 2-21. Shoreline change rates based on linear regression analysis for the Main Pass, La., navigation canal, 1978-2006 (map 2 of 3). The background imagery consists of 2005 aerial photographs. 


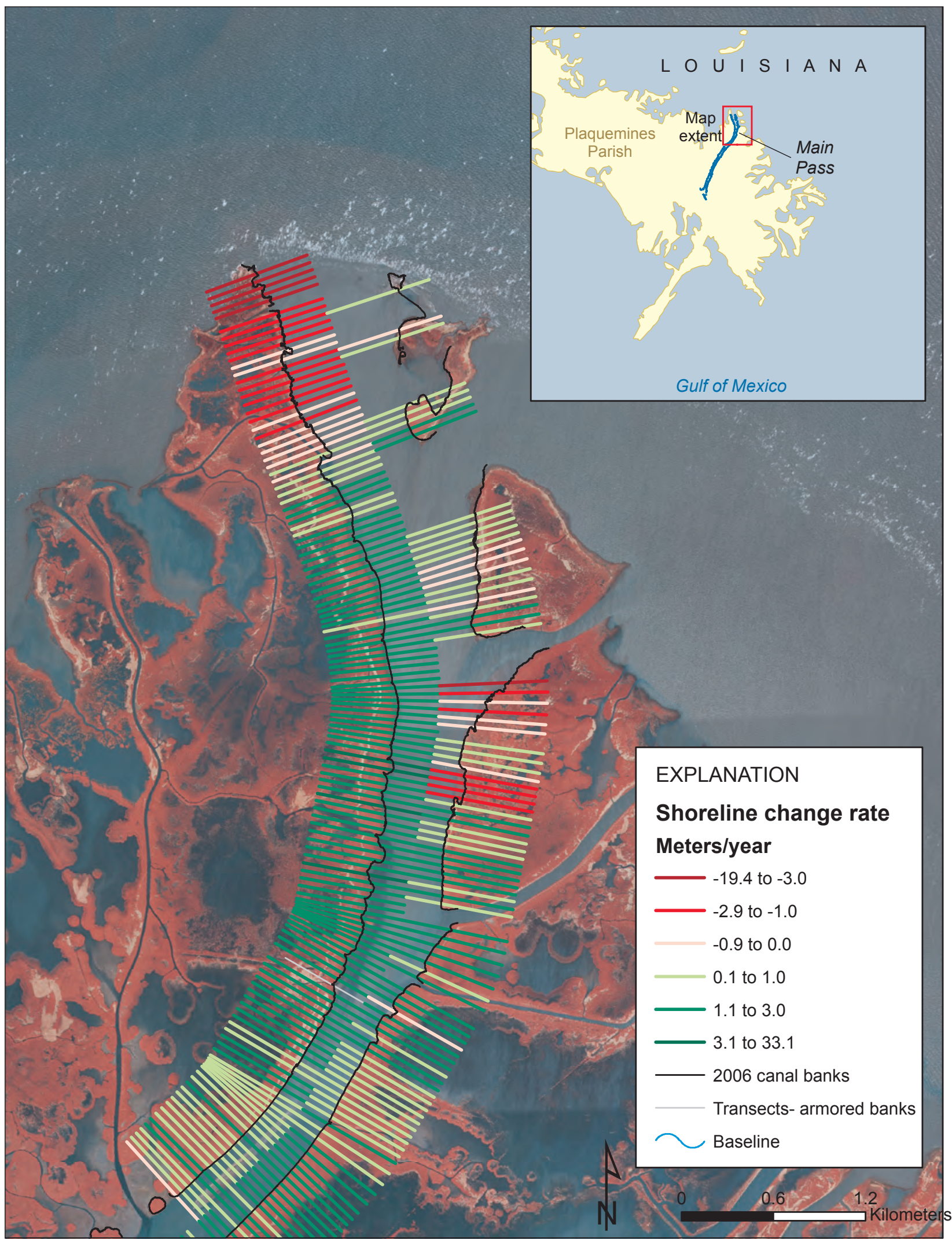

Figure 2-22. Shoreline change rates based on linear regression analysis for the Main Pass, La., navigation canal, 1978-2006 (map 3 of 3). The background imagery consists of 2006 aerial photographs. 


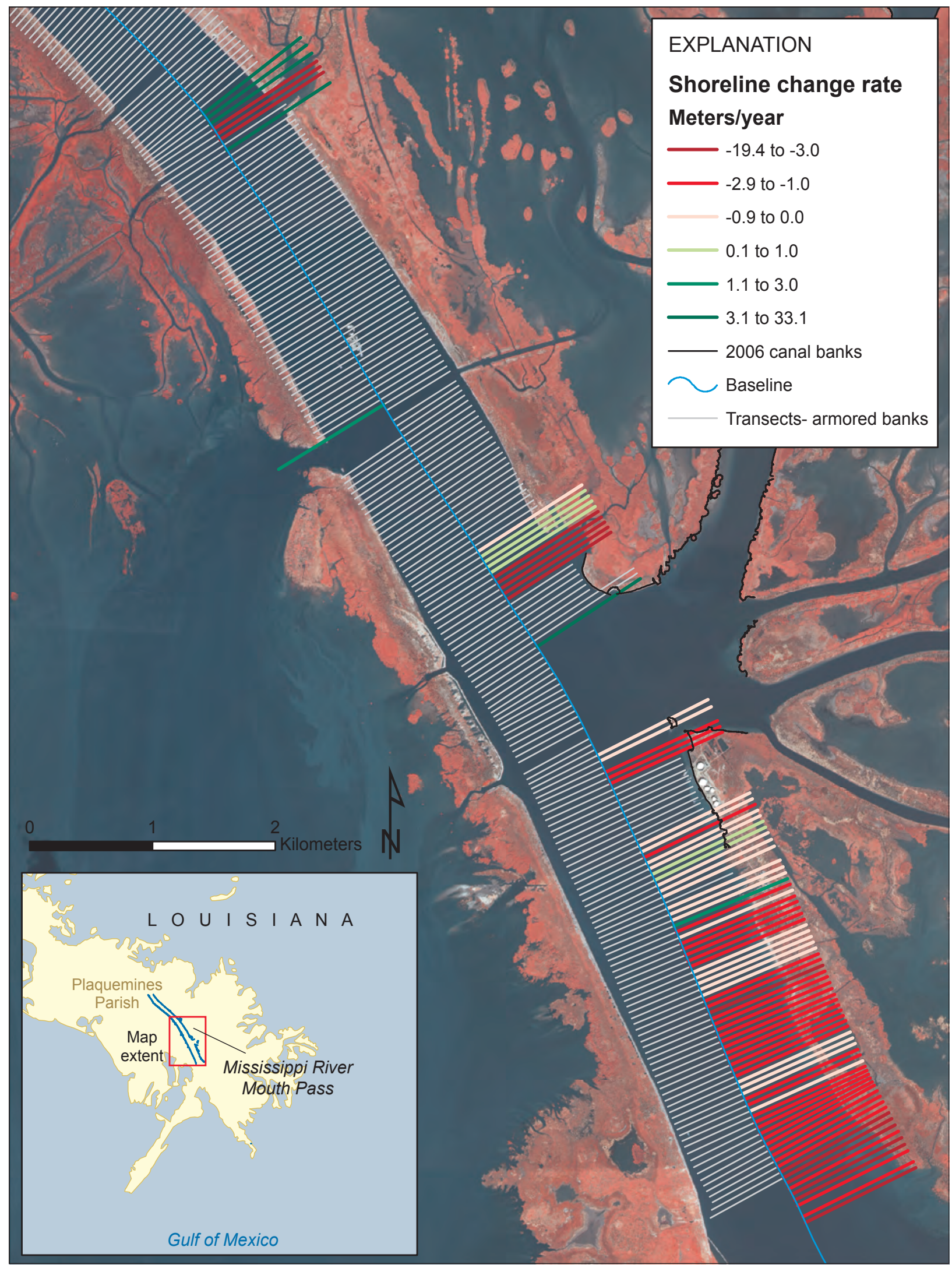

Figure 2-23. Shoreline change rates based on linear regression analysis for Mississippi River Mouth Pass, La. (Map 1 of 2; Mississippi River from Venice, La., to the Head of Passes). The background imagery consists of 2005 aerial 


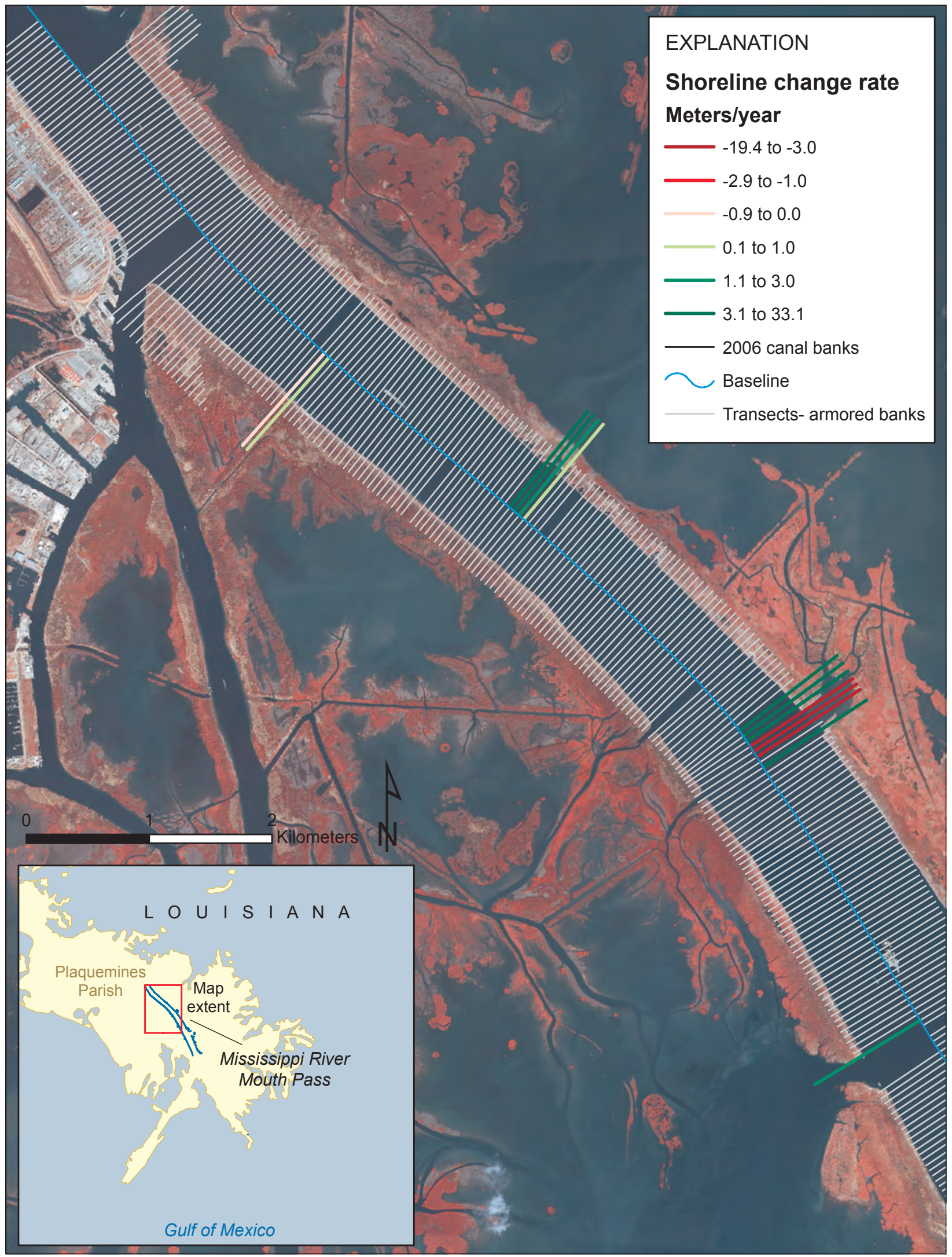

Figure 2-24. Shoreline change rates based on linear regression analysis for Mississippi River Mouth Pass, La. (Map 2 of 2; Mississippi River from Venice, La., to the Head of Passes). The background imagery consists of 2005 aerial photographs. 




Figure 2-25. Rates of shoreline change for the Pascagoula Channel, Miss., 1979-2006 (map 1 of 2). Rates were derived by using linear regression analysis. The background imagery consists of 2006 aerial photographs. 


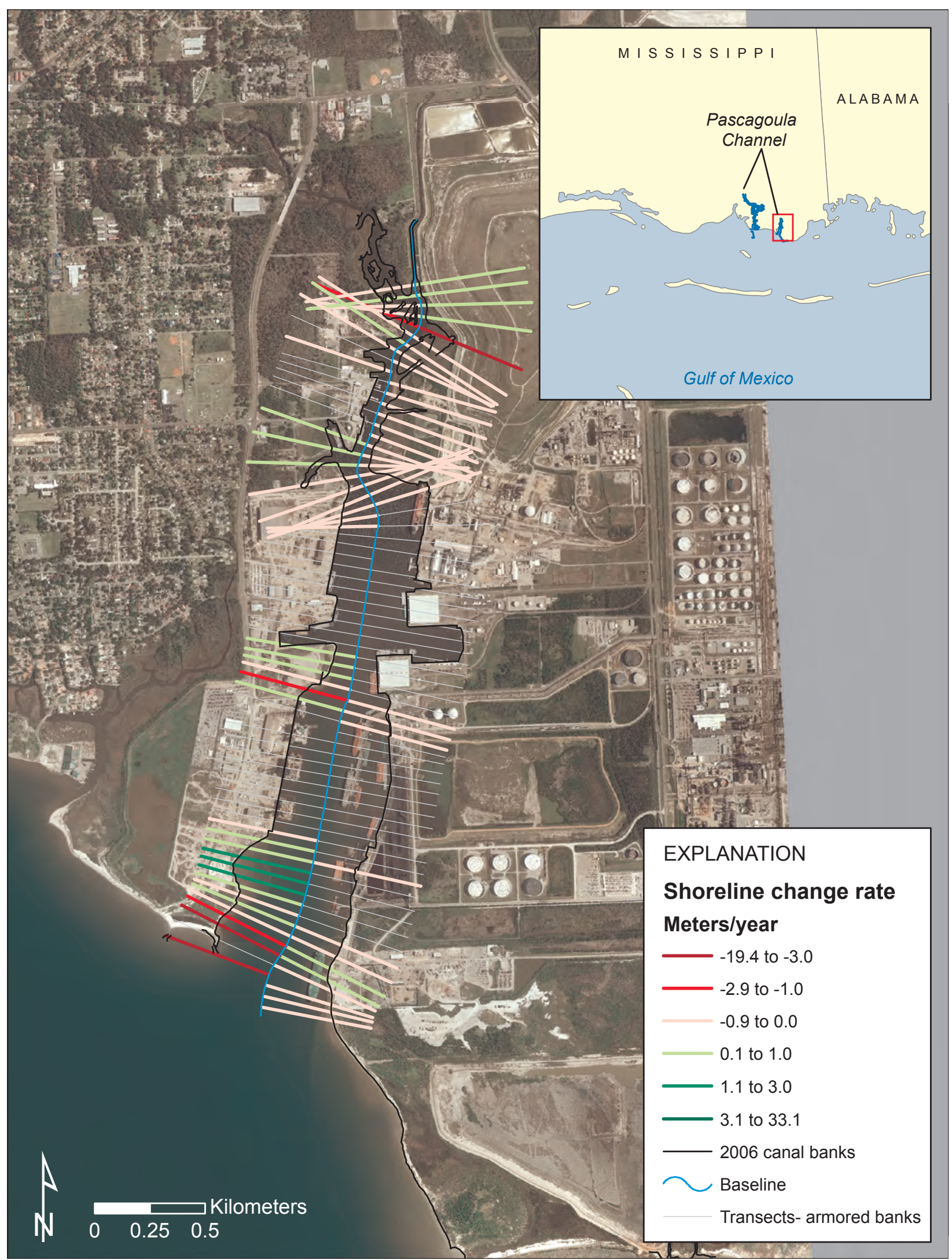

Figure 2-26. Shoreline change rates based on linear regression analysis for the Pascagoula Channel, Miss., navigation canal, 1979-2006 (map 2 of 2). The background imagery consists of 2006 aerial photographs. 


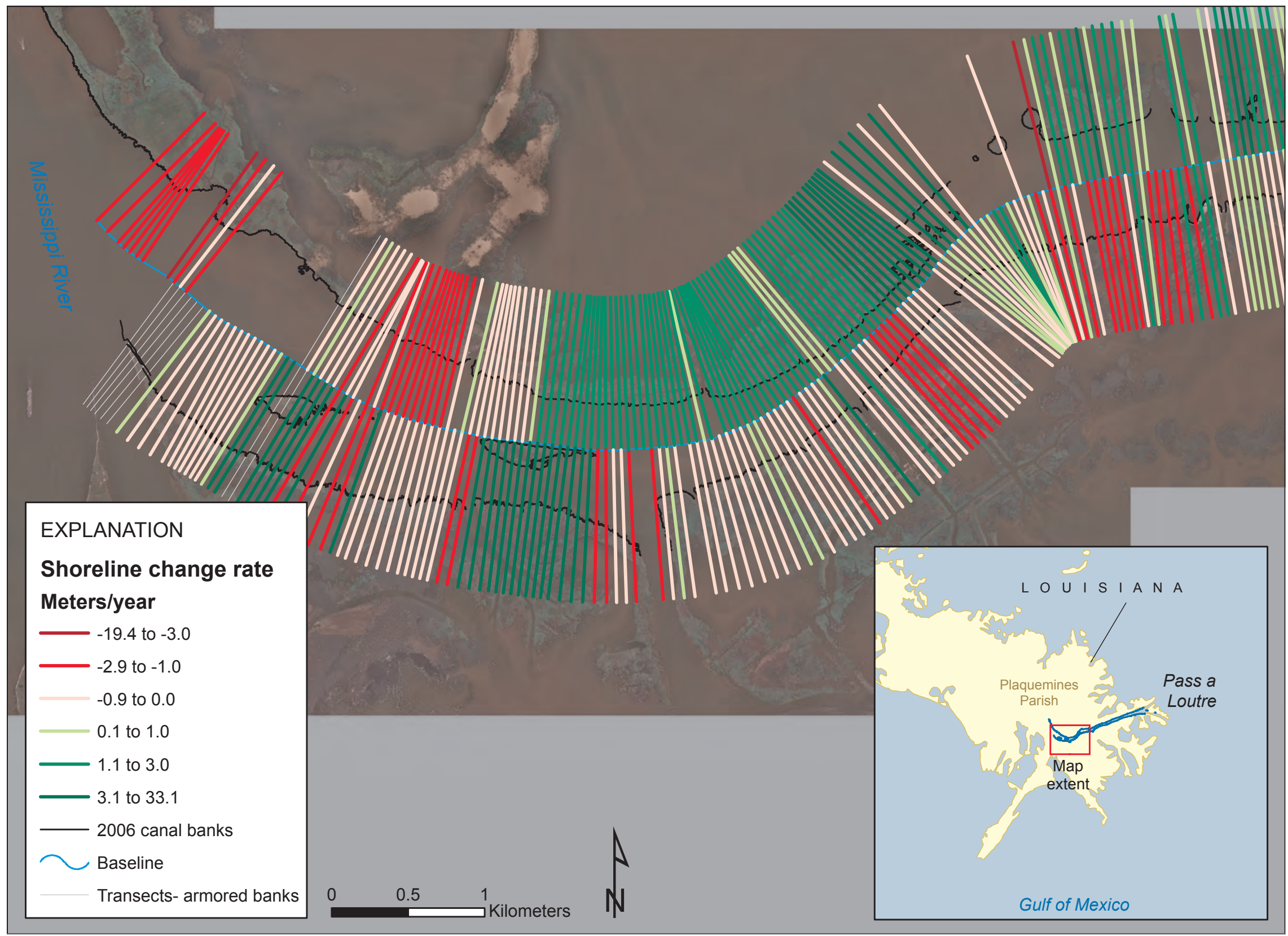

Figure 2-27. Rates of shoreline change for the Pass a Loutre channel, La., 1978-2006 (map 1 of 3). Rates were derived by using linear regression analysis. The background imagery consists of 2006 aerial photographs. 


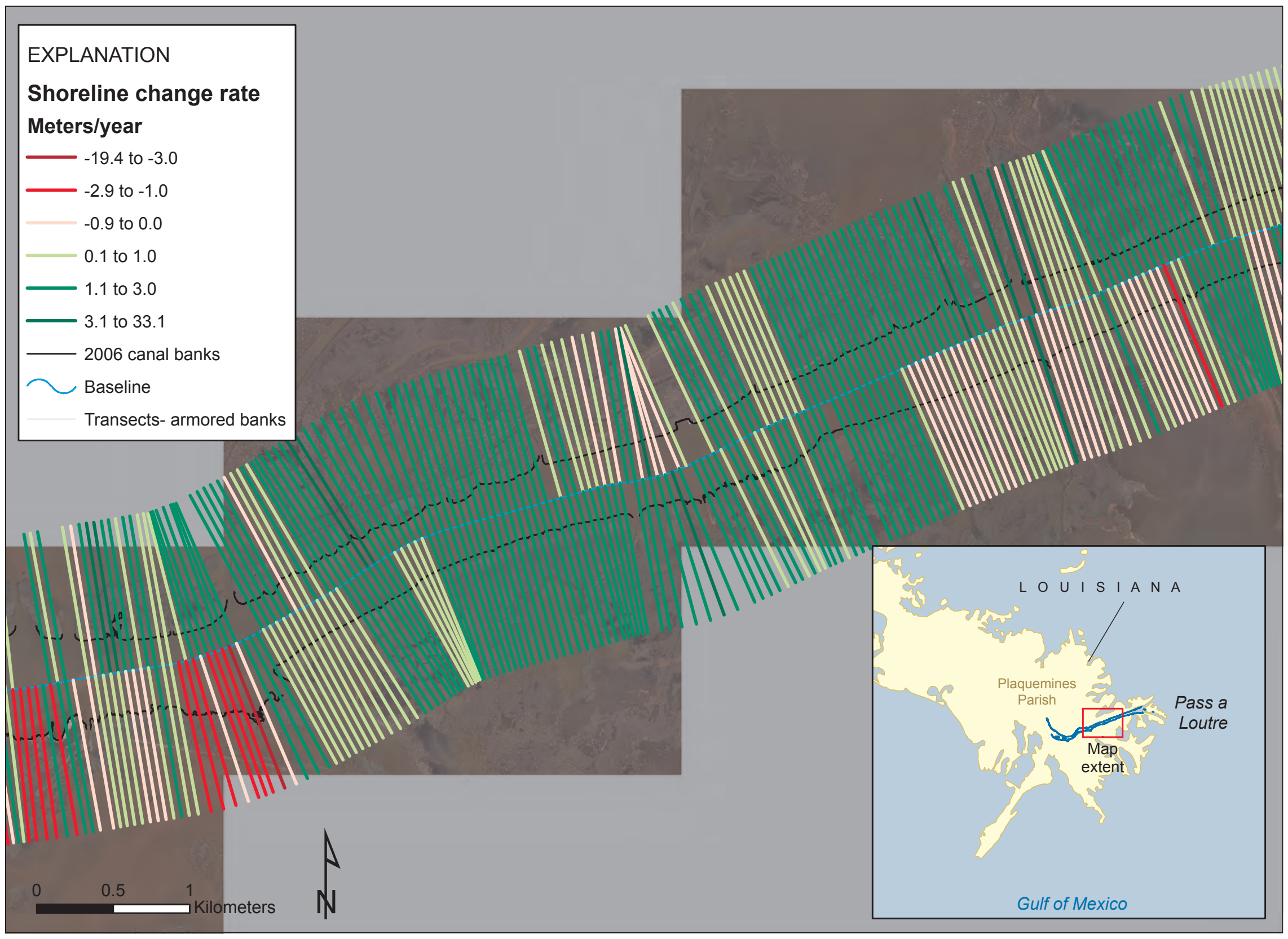

Figure 2-28. Shoreline change rates based on linear regression analysis for the Pass a Loutre, La., navigation canal, 1978-2006 (map 2 of 3). The background imagery consists of 2006 aerial photographs. 


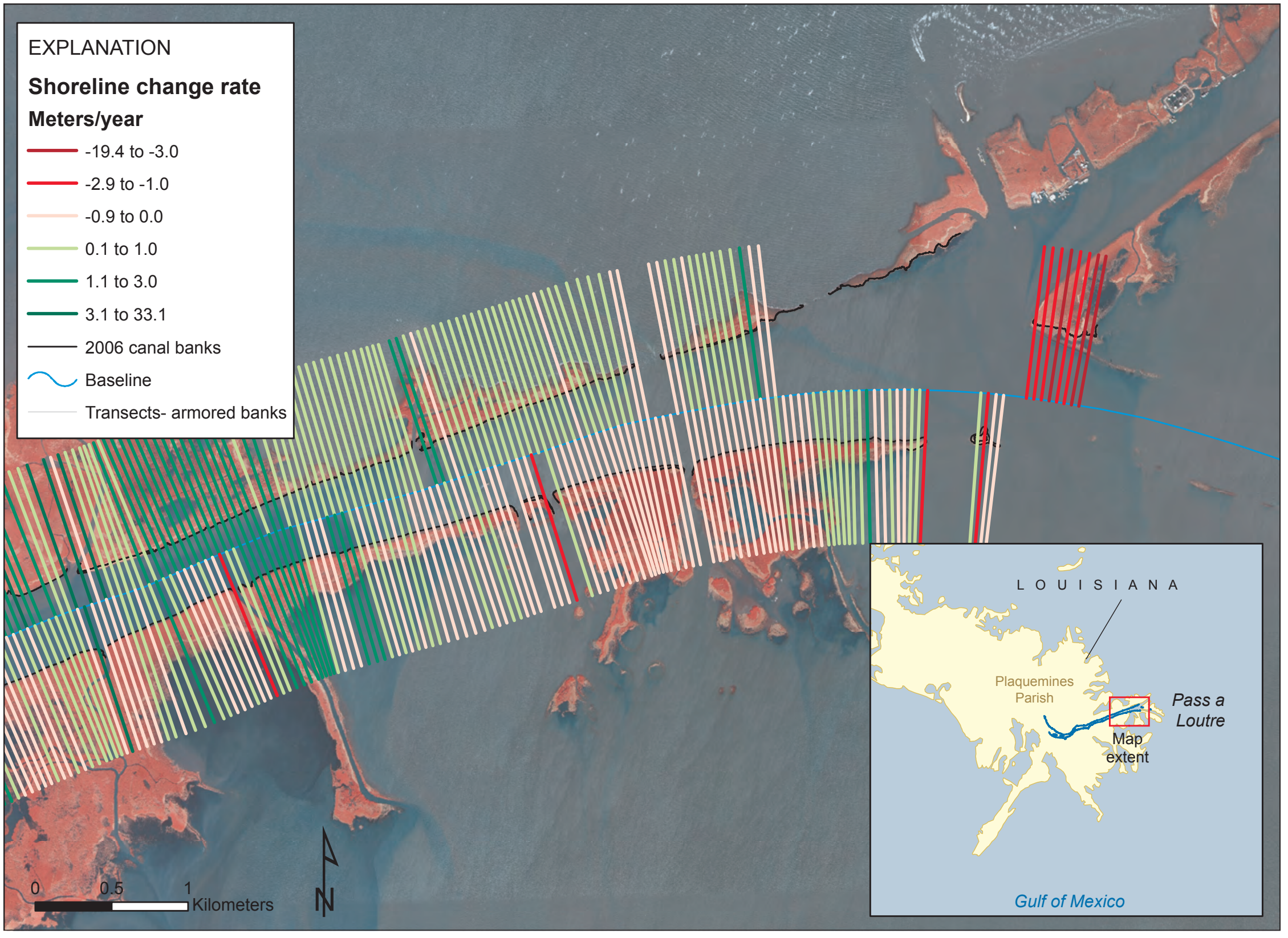

Figure 2-29. Shoreline change rates based on linear regression analysis for the Pass a Loutre, La., navigation canal, 1978-2006 (map 3 of 3). The background imagery consists of 2005 aerial photographs 


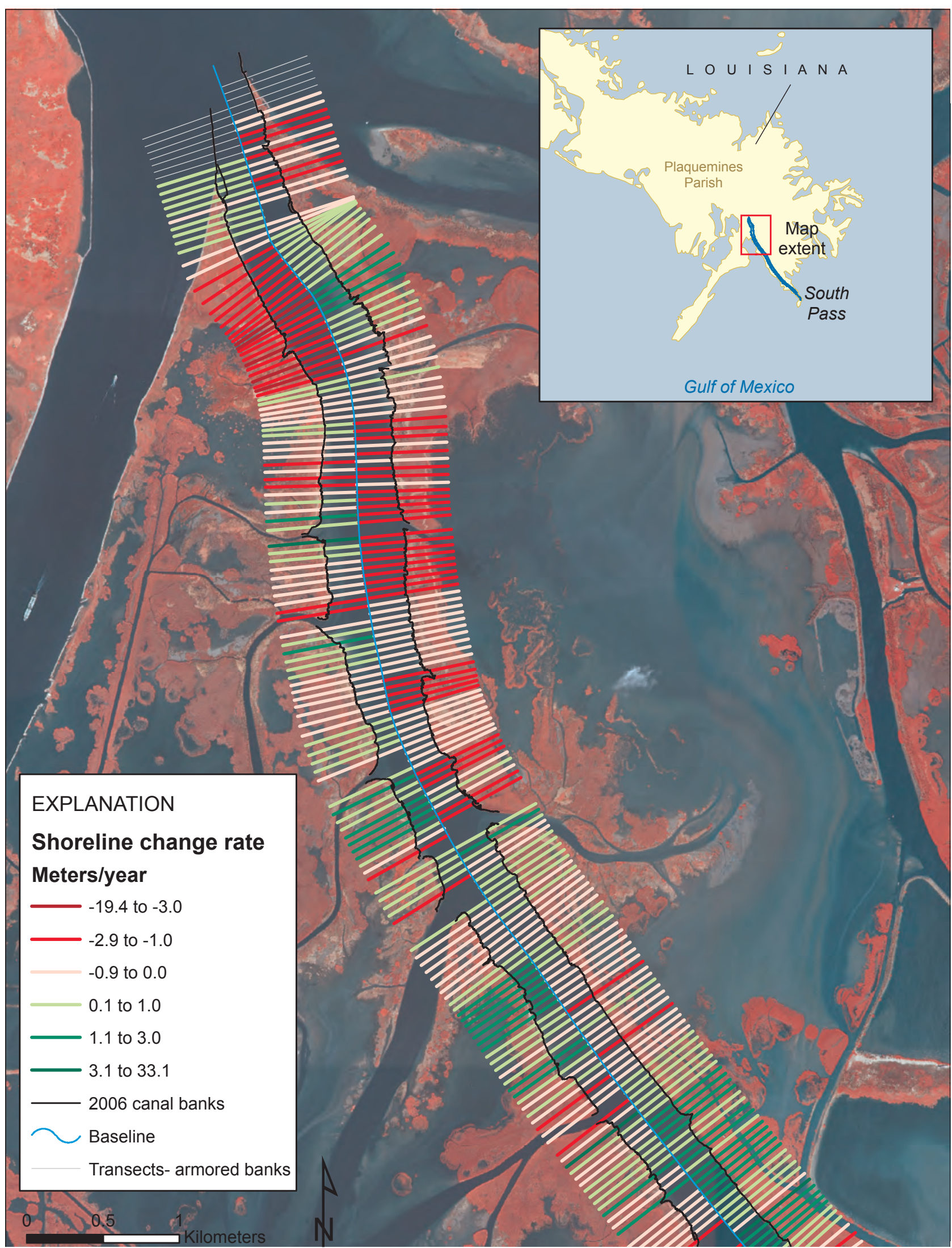

Figure 2-30. Rates of shoreline change for the South Pass channel, La., 1978-2006 (map 1 of 3). Rates were derived by using linear regression analysis. The background imagery consists of 2005 aerial photographs. 


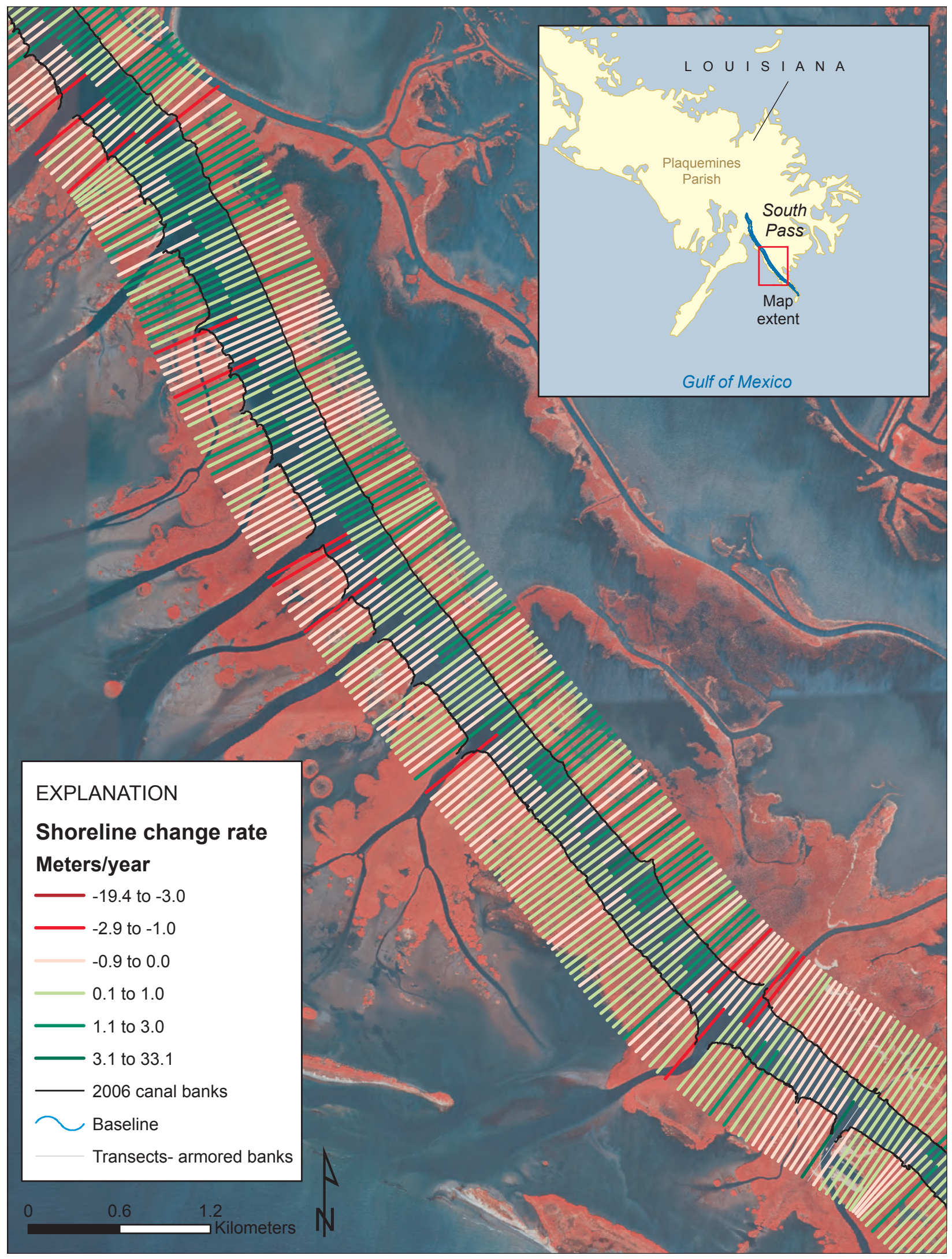

Figure 2-31. Shoreline change rates based on linear regression analysis for the South Pass, La., navigation canal, 1978-2006 (map 2 of 3). The background imagery consists of 2005 aerial photographs. 


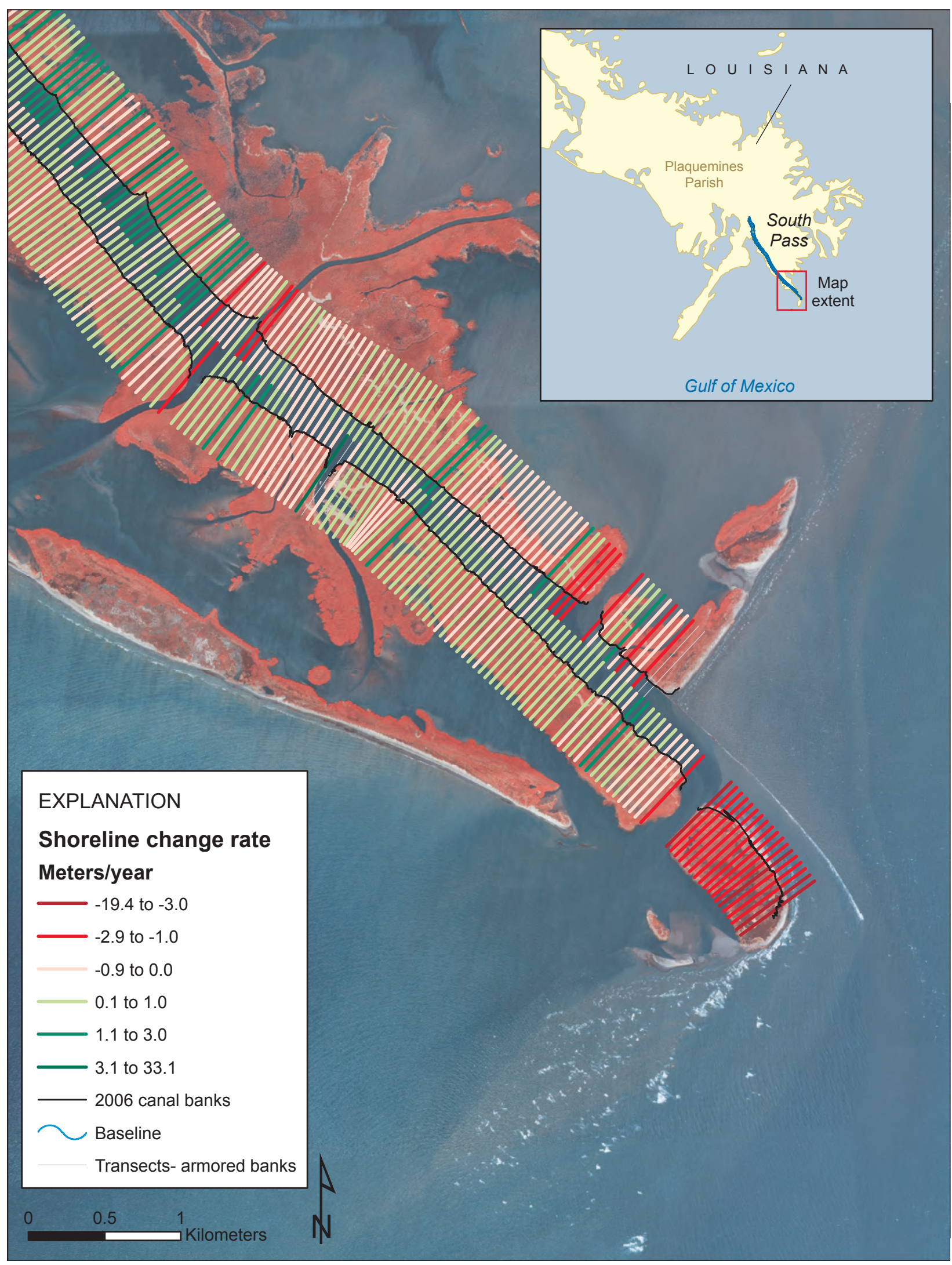

Figure 2-32. Shoreline change rates based on linear regression analysis for the South Pass, La., navigation canal, 1978-2006 (map 3 of 3). The background imagery consists of 2005 aerial photographs. 




Figure 2-33. Shoreline change rates based on linear regression analysis for the Southwest Pass, La., navigation canal, 1978-2006 (map 1 of 4). The background imagery consists of 2005 aerial photographs. 




Figure 2-34. Shoreline change rates based on linear regression analysis for the Southwest Pass, La., navigation canal, 1978-2006 (map 2 of 4). The background imagery consists of 2005 aerial photographs. 


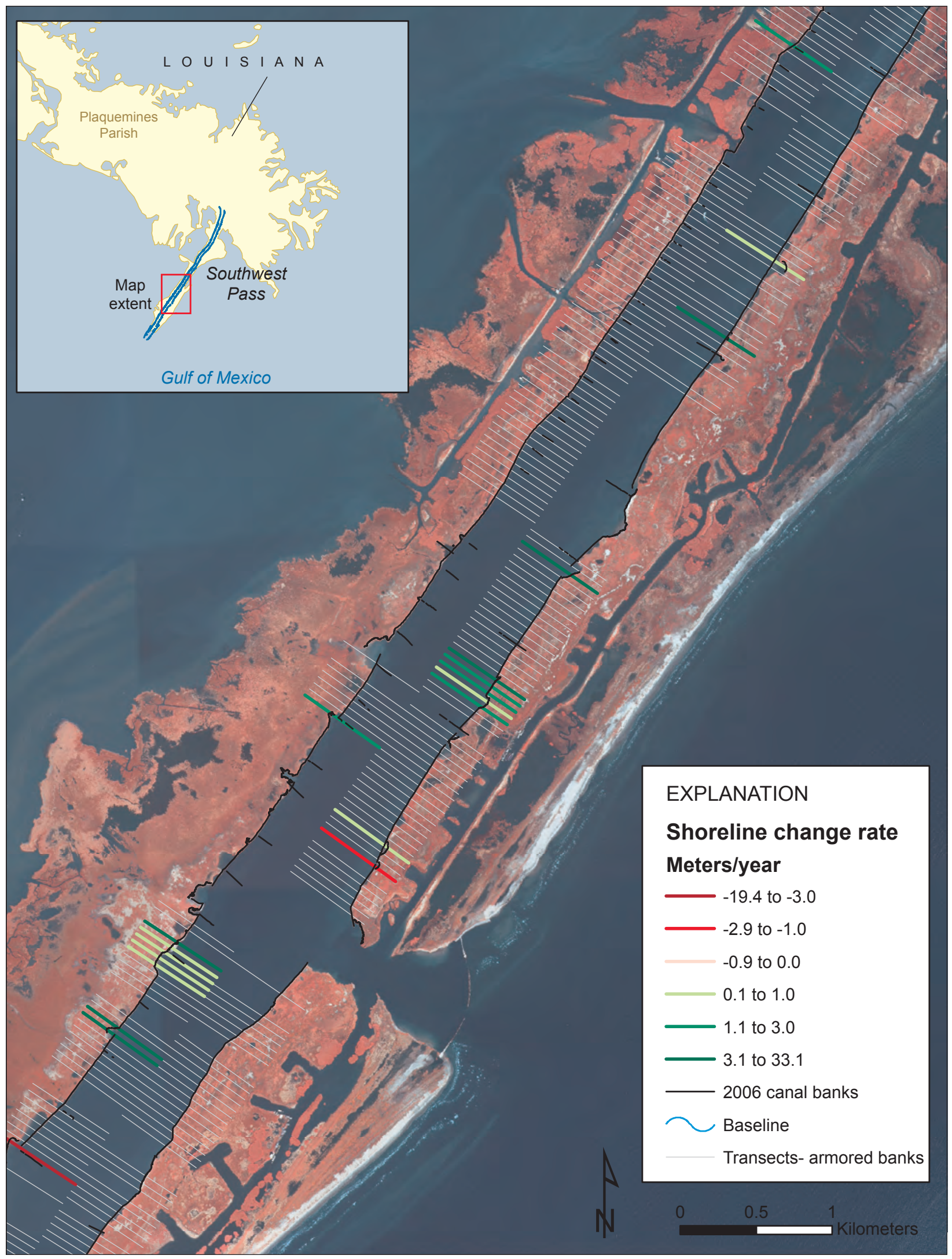

Figure 2-35. Shoreline change rates based on linear regression analysis for the Southwest Pass, La., navigation canal, 1978-2006 (map 3 of 4). The background imagery consists of 2005 aerial photographs. 




Figure 2-36. Shoreline change rates based on linear regression analysis for the Southwest Pass, La., navigation canal, 1978-2006 (map 4 of 4). The background imagery consists of 2005 aerial photographs. 




Figure 2-37. Rates of shoreline change for the Theodore Ship Channel, Ala., 1979-2006 (map 1 of 1). Rates were derived by using linear regression analysis. The background imagery consists of 2006 aerial photographs. 




Figure 2-38. Shoreline change rates based on linear regression analysis for the Tiger Pass channel, La., 1978-2006 (map 1 of 2). The background imagery consists of 2005 aerial photographs. 


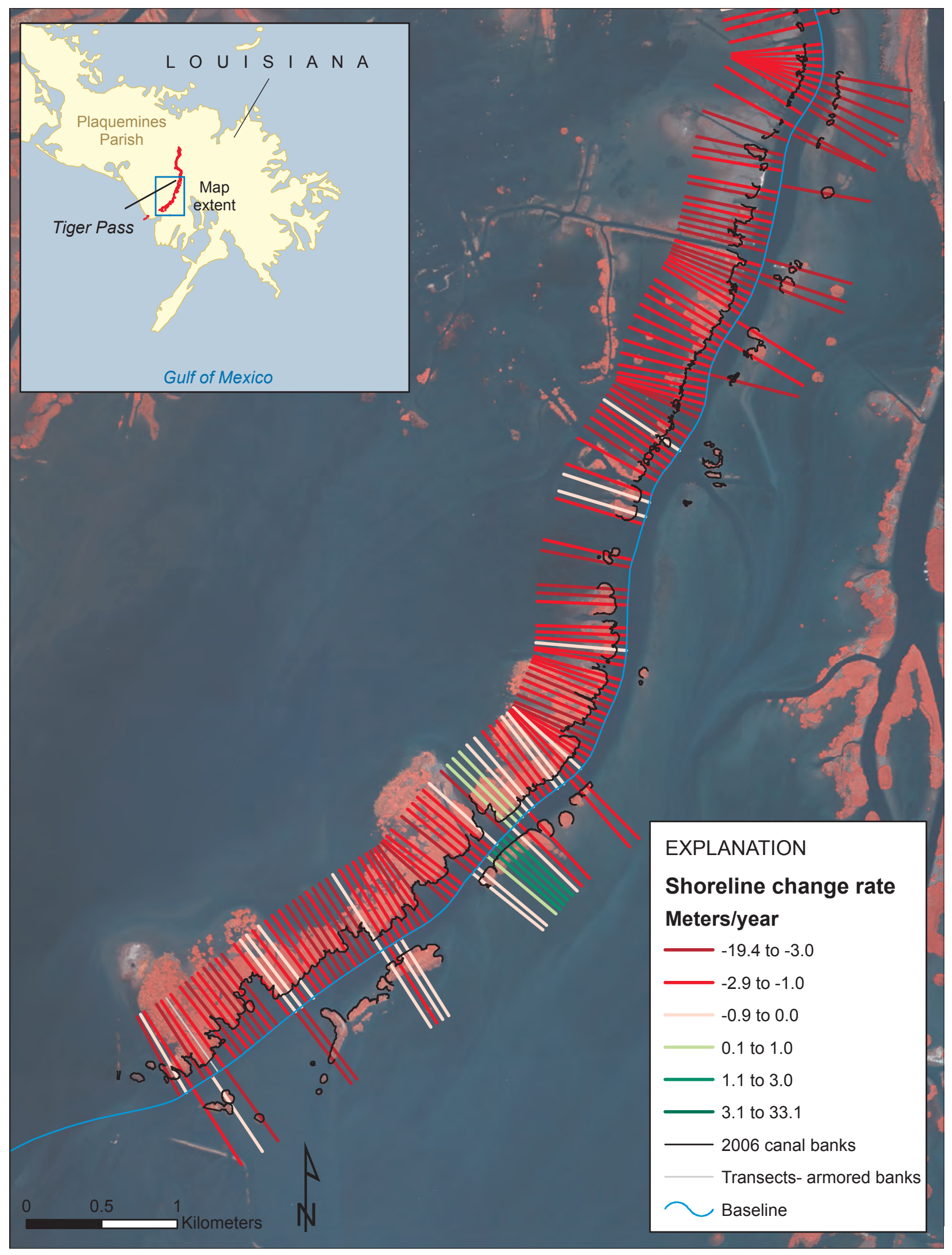

Figure 2-39. Shoreline change rates based on linear regression analysis for the Tiger Pass, La., navigation canal, 1978-2006 (map 2 of 2). The background imagery consists of 2005 aerial photographs. 
Publishing support provided by the Lafayette Publishing Service Center 
